\title{
Provisions For Drilling Wells And Their Effects In Islamic Jurisprudence And Positive Law (A Comparative Study)
}

Dr.Assist. Prof. Saddam Hussein Yassin Al- Obeidi/ College of the Al- Emam Al- Aadam University Kirkuk/msaddamalobide953@gmail.co /07706104480

Abstract: Water is the secret of life. All living organisms are indispensable، and water may be absent or scarce in some areas، so a person resorts to digging wells to provide his need of water، and while digging these wells، He may commit some illegitimate or illegal violations, so this research came to explain the jurisprudence provisions And the legality of drilling wells، and what are the places in which wells may or may not be drilled, and what are the terms، conditions and instructions for drilling wells، and what is the rule of guaranteeing a well-digger for the death or damage of a person، animal or money in it in Islamic jurisprudence and positive law. Then I conclude the research with a conclusion that included the most important findings and recommendations we have reached.

Keywords: (provisions، drilling، wells، Islamic jurisprudence، positive law، guarantee) 


\section{أحكام حفر الآبار وآثارها في الفقه الإسلامي والقانون الوضعي (دراسة مقارنة) \\ ا. م. د. صدام حسين ياسين العبيدي/كلية الإمام الأعظم الجامعة/كركوك / مك 07706104480 / msaddamalobide953@gmail.co}

الماء سر الحياة، فجميع الكائنات الحية لا تستغني عنه، وقد ينعدم الماء أو يشح في بعض المناطق، لذإ الذا يلجأ

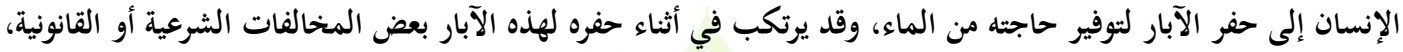

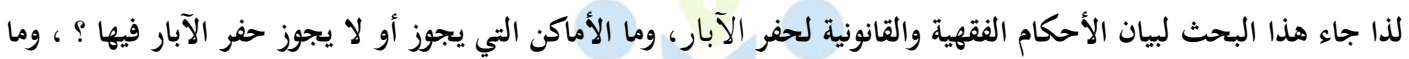

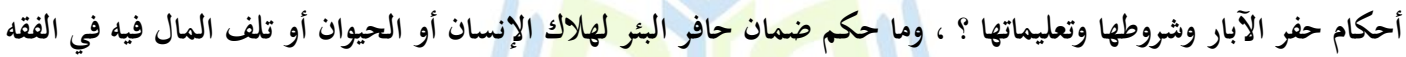

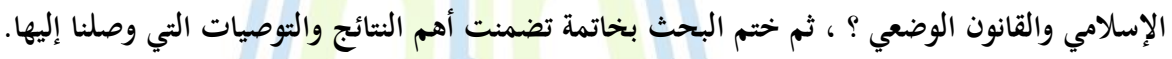

الكلمات المفتاحية: (أحكام، حفر، آبار، الفقه الإسلامي، القانون الوضعي، ضمان). 


\section{أحكام حفر الآبار وآثارها في الفقه الإسالامي والقانون الوضعي (دراسة مقارنة) \\ ا. م. د. د. صدام حسين ياسين العبيدي

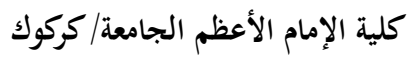

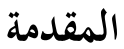

$$
\text { الحمد لله رب العالمين والصلاة والسلام على سيدنا محمد وعلى آله وصحبة أجمعين. }
$$

الماء أصل الوجود في هذه الحياة، فهو أصل الحياة الإنسانية والحيوانية والنباتية، قال تعالى: رَجَعَلْنَا مِنَ

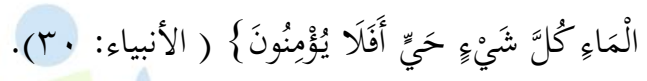

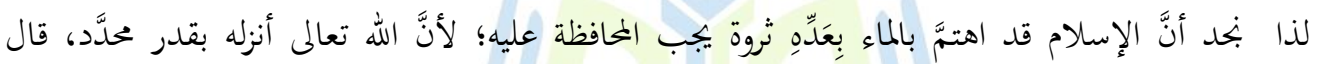

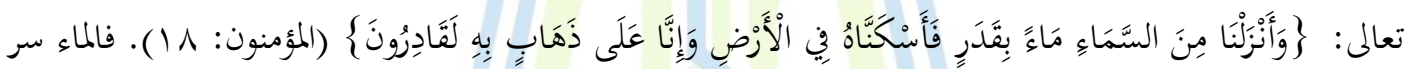

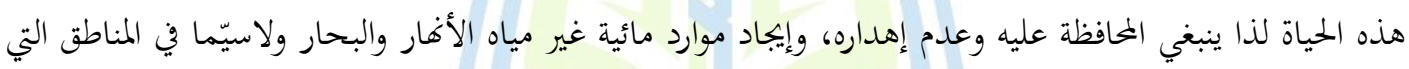

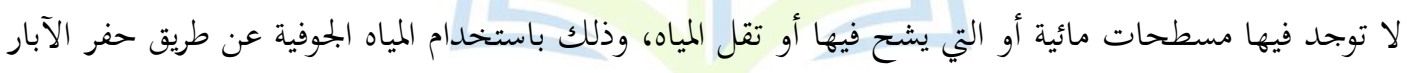

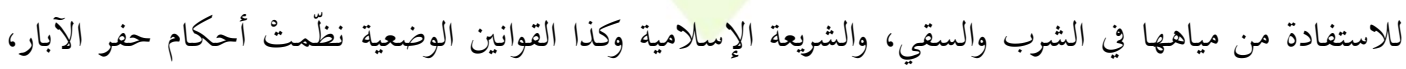

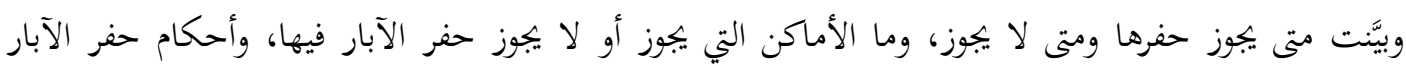

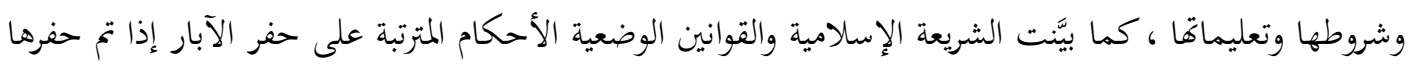

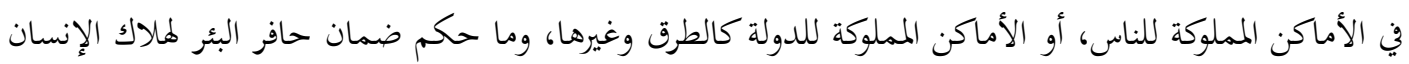

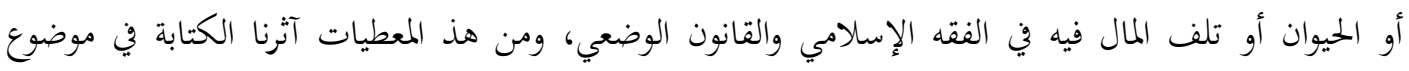

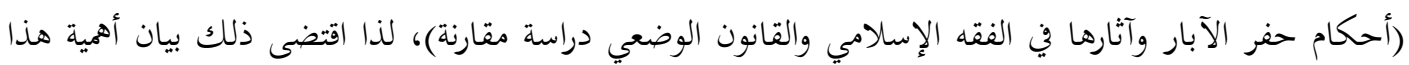

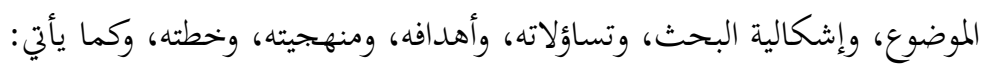

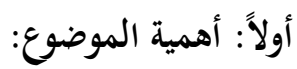


حفلت كتب الفقه الإسلامي بالأحكام الخاصة بحفر الآبار في الطرق العامة والأماكن الخاصة، وتعد هذه

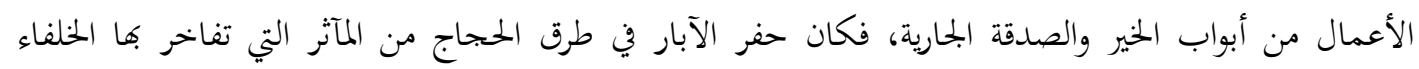

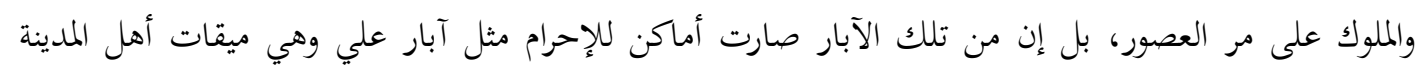

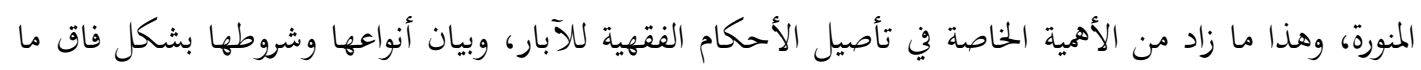

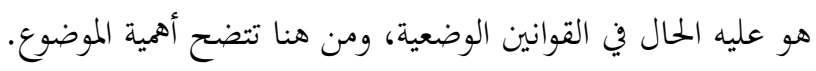
ثانياً: إشكالية البحث:

لا شك أن سقي الماء من أفضل الأعمال والصدقات، والإسلام دعا أهل الغنى والمال للتبرع بحفر الآبار،

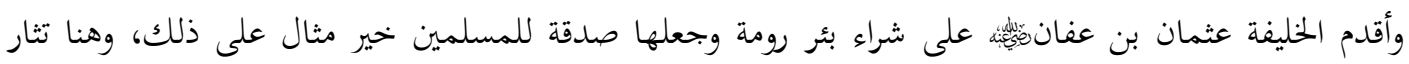

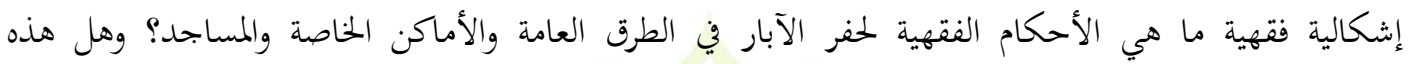

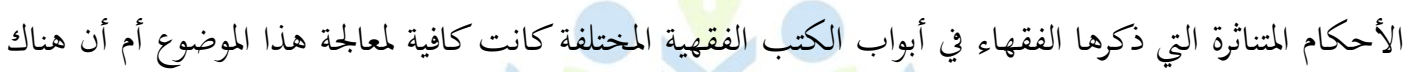

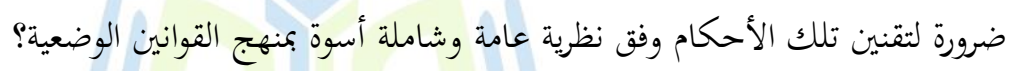

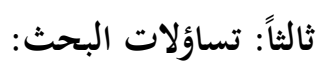

إن التسليم بفضل العمل في حفر الآبار وسقي الماء يقود إلى تساؤلات تتطلب الإجابة عليها، وهي تمثل

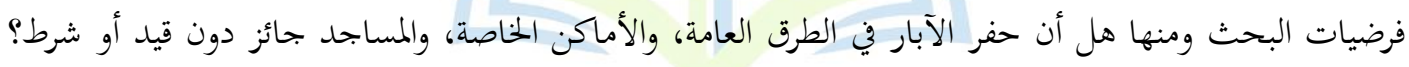

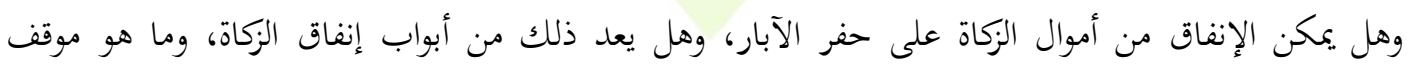

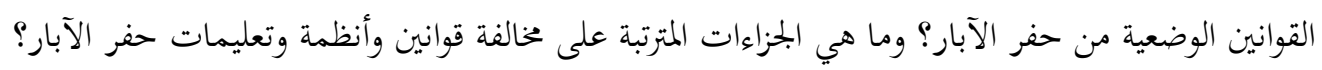

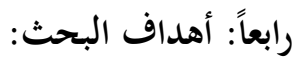

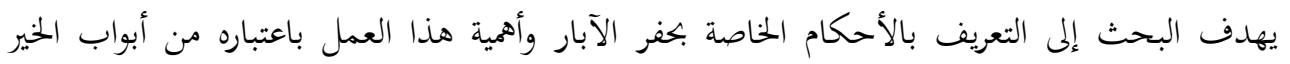

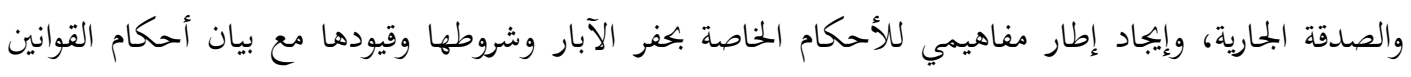

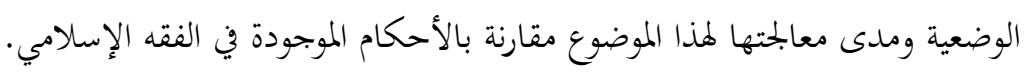

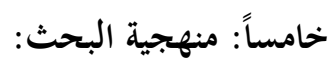
67

Doi:10.37940/RJIS. 2021.2.1.3 
للوصول إلى إجابات عن تساؤلات البحث وفرضياته تم الاستعانة بالمنهج التحليلي الذي يقوم على تحليل

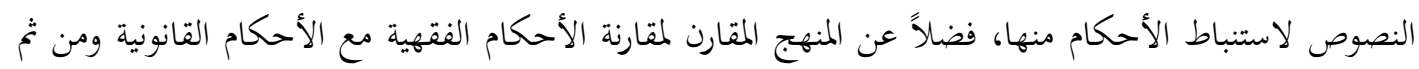
الوصول إلى النتائج المرجوة من البحث من الناحية الفقهية والقانونية.

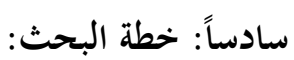

اقتضت طبيعة البحث تقسيمه إلى مقدمة وثلاثة مباحث، خصصنا المبحث الأول للتعريف بالآبار في الفقه

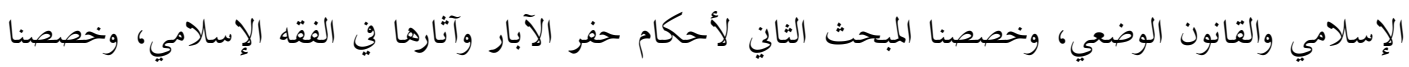

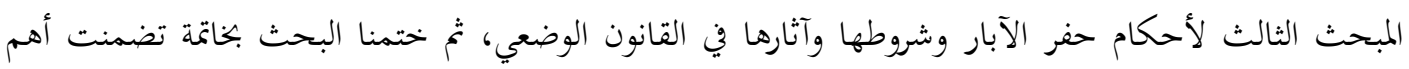
النتائج والتوصيات التي توصلنا إليها.

\section{المبحث الأول: التعريف بالآبار في الفقه الإسلامي والقانون الوضعي}

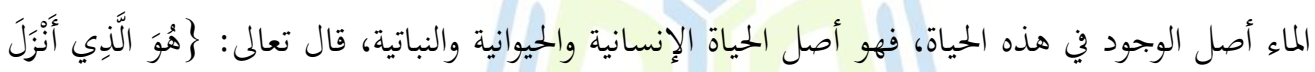

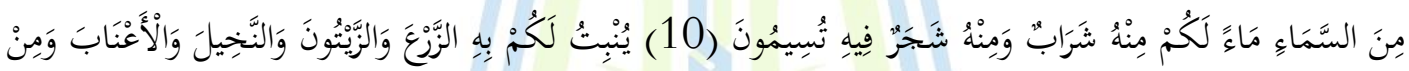

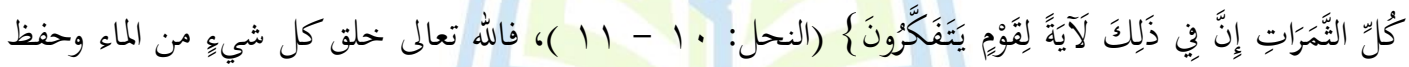
حياة كل شيء حيِّ بالماء (1).

والماء معجزة إلهية عجز الإنسان حتى الآن عن الوصول إلى صنعها، وتكمن أهمية الماء بالنسبة للإنسان

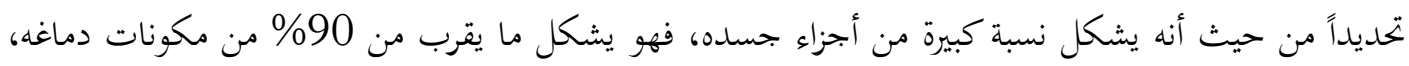

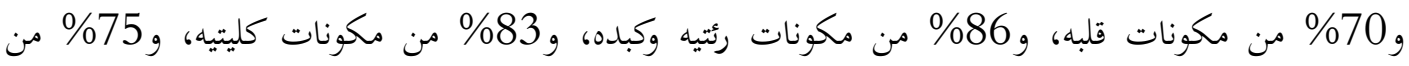

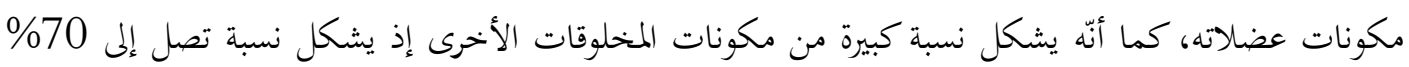
من مكونات الحيوان، و90\% من مكونات النبات (2).

$1{ }^{1}$ ينظر: القرطب، أبو عبدالله محمد بن أحمد بن أبي بكر، الجامع لأحكام القرآن، تحقيق الدكتور عبدالله بن عبدالمحسن

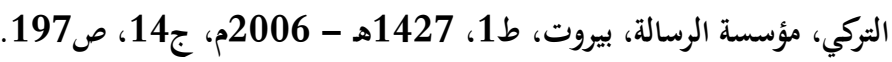

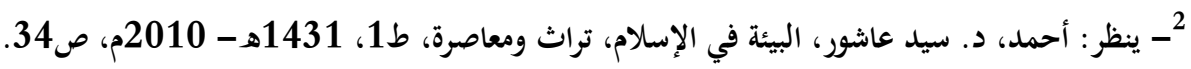


وزيادة على ذلك بند أنَّ للماء وظيفة اجتماعية دينية، وهي تطهير البدن والملبس والمكان من الأوساخ

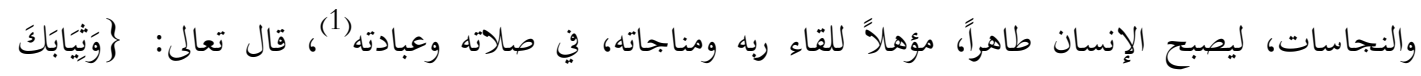

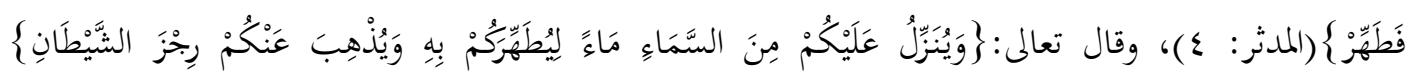

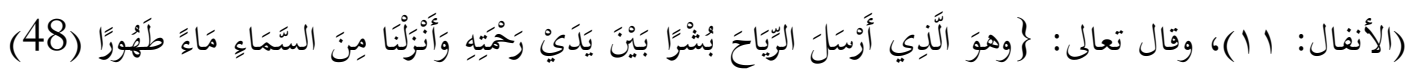

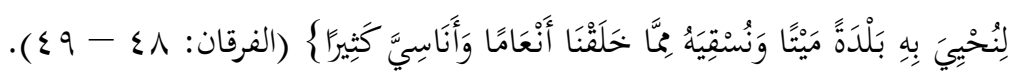

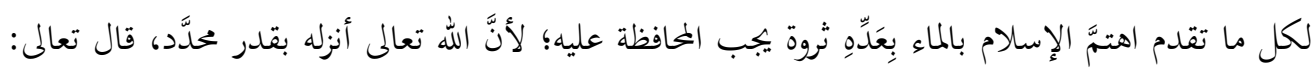

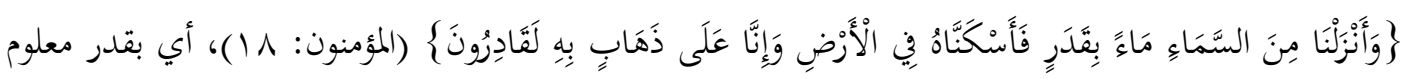
ومحََّد وهو مقدار كفايتهم (2).

فالماء سر الحياة لذا ينبغي المحافظة عليه وعدم إهداره، وإيجاد موارد مائية غير مياه الأهمار والبحار ولاسيّما

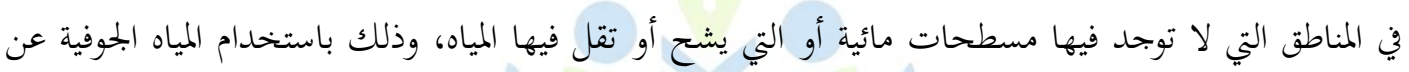

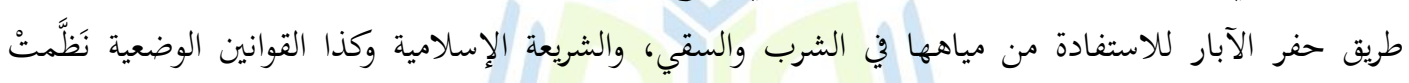

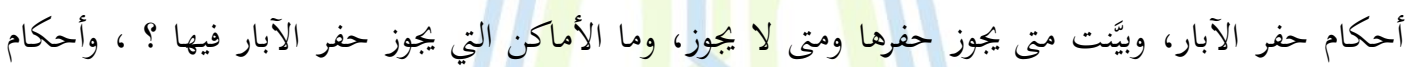

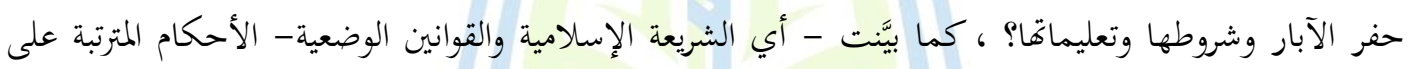

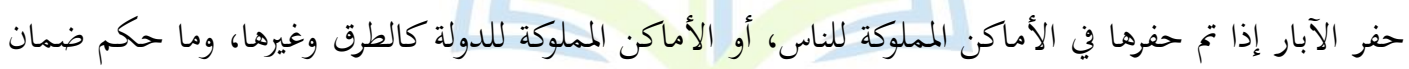

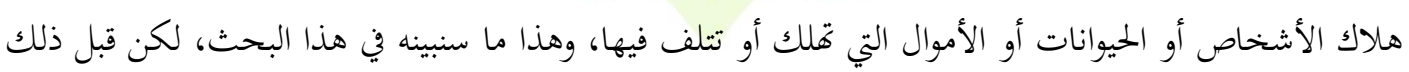

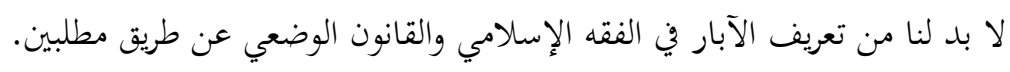

1ــ ينظر: شحاتة، د. عبدالله، رُؤية الدين الإسلامي في الحفاظ على البيئة، دار الشروق، القاهرة، 1421هـ- 2001م،

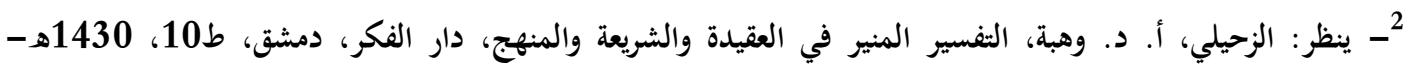
2009م، م9، ج18، ص345. 


$$
\text { المطلب الأول: تعريف الآبار في الفقه الإسلامي }
$$

يقتضي تعريف الآبار في الفقه الإسلامي أنْ نُعرِّها أولاً في اللغة، ثم نُعرِّفها في الفقه الإسلامي وذلك عن

طريق فرعين. الفرع الأول: الآبار لغةً

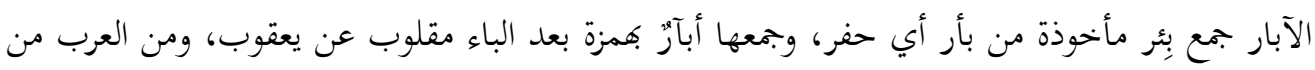

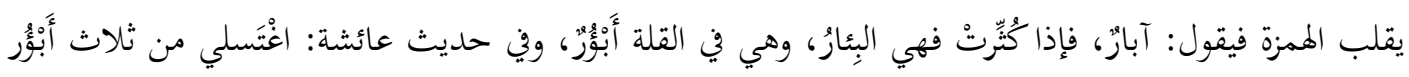

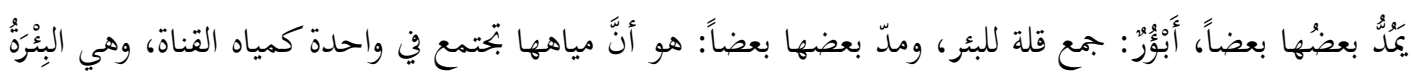

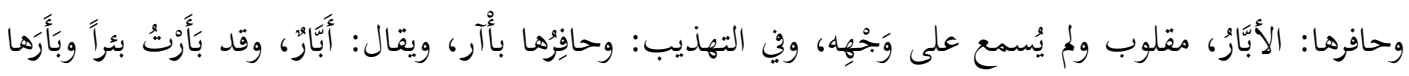

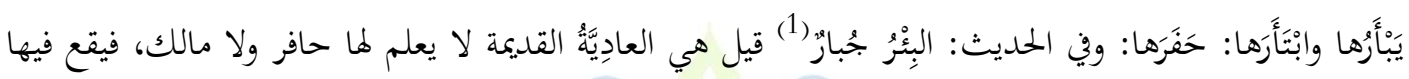

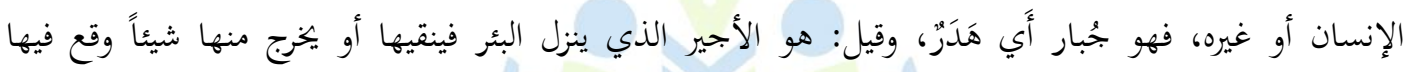
فيموت (2)

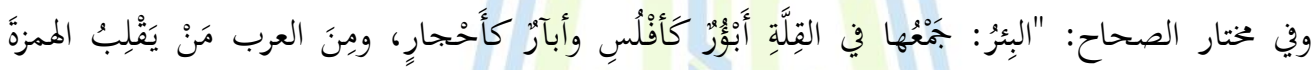

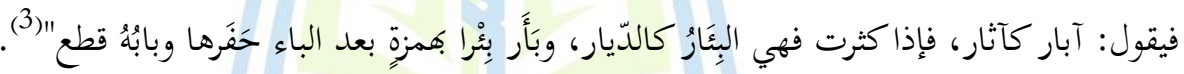

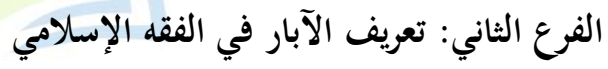

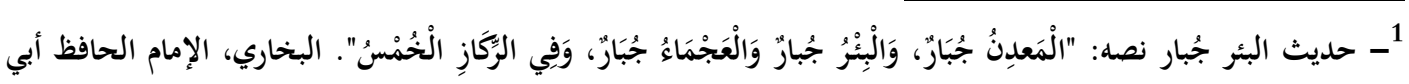

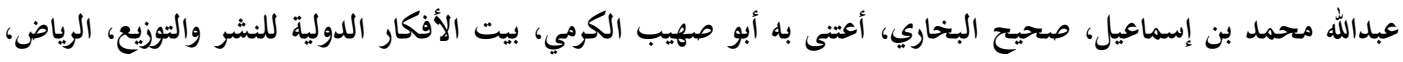

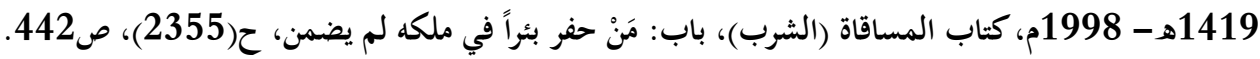

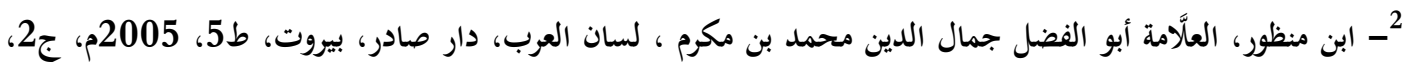

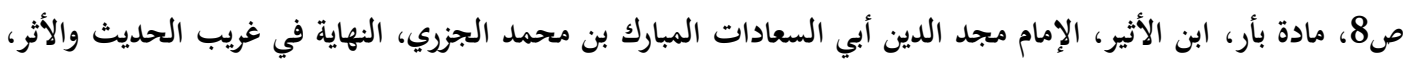

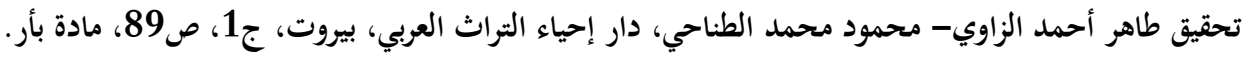

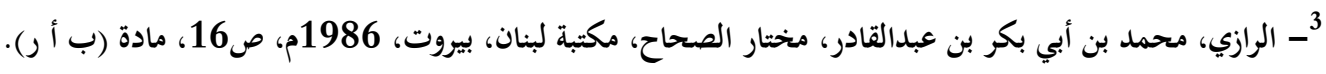


ينقل ابن عابدين في حاشيته عن النتف أنَّ البئر هي التي لها مواد من أسفلها، أي لها مياه تمدها وتنبع من

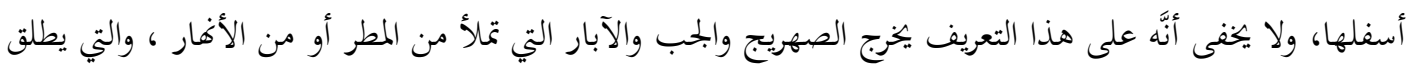

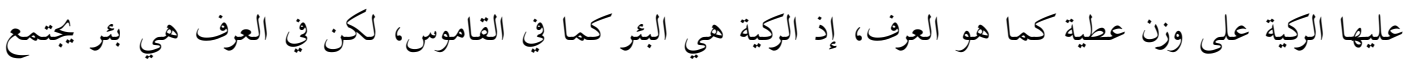
ماؤها من المطر أي فهي بمعنى الصهريج (1).

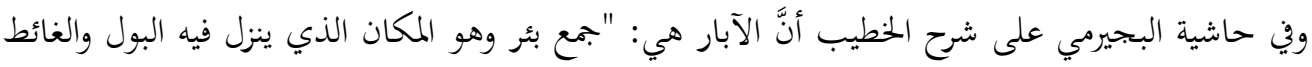

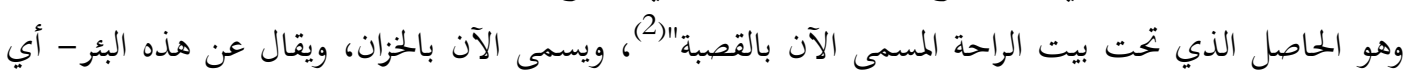

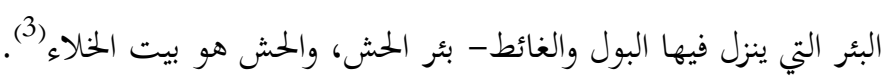

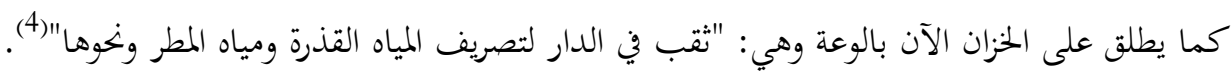

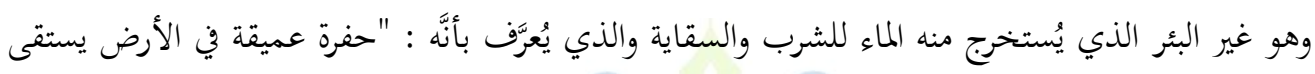

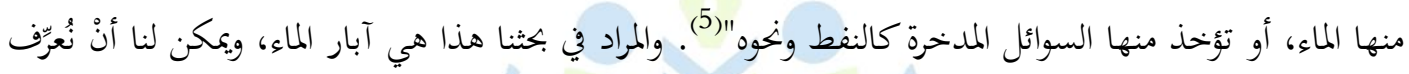
البئر بأنَّه : ثقب أو حفرة تعمل في الأرض باستخدام آلات الحفر وأدواته لاستخراج المياه للشرب ولئا وللسقاية. المطلب الثاني: تعريف الآبار في القانون الوضعي توني

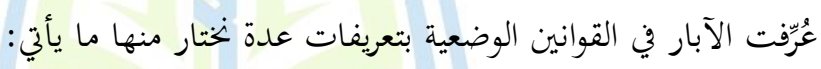

1 1ـــينر : ابن عابدين، محمد أمين، رد المحتار على الدرّ المختار شرح تنوير الأبصار، دراسة وتحقيق وتعليق الشيخ عادل

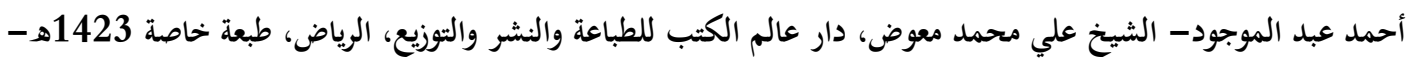

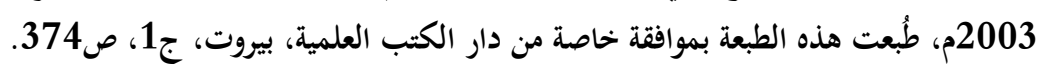

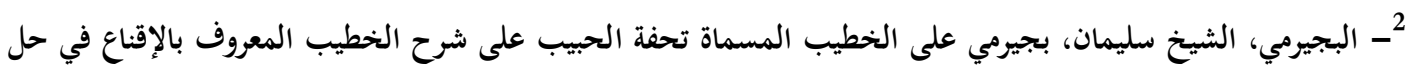

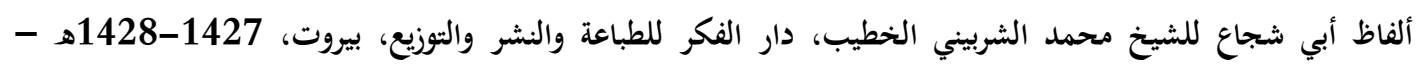

$$
\text { 2007م، ج3، ص102. }
$$

3ـ ينظر: الموسوعة الفقهية، وزارة الأوقاف والشؤون الإسلامية بدولة الكويت، طباعة ذات السلاسل، الكويت، ط2007،

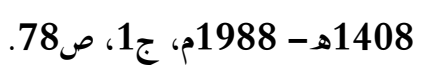

4- قلعه جي، د. محمد رواس، معجم لغة الفقهاء، دار النفائس، بيروت، ط38، 1431هـ - 2010، 2010م، ص83.

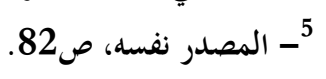




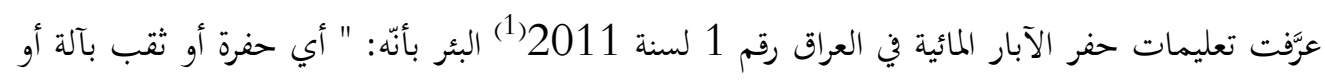

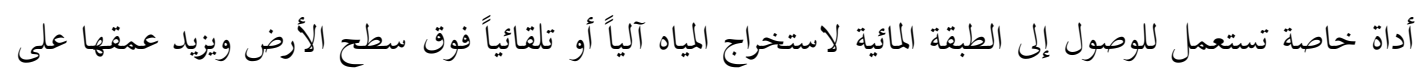

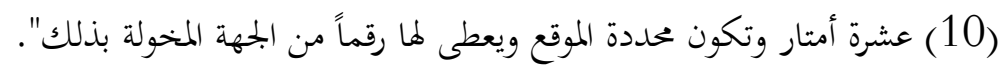

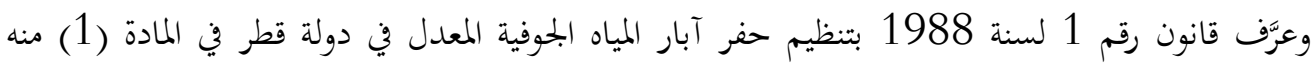

البئر : "أي حفرة أو خندق أو ثقب يتم إحداثه في الأرض بآلة أو جهاز للوصول إلى المياه الجوفية واستخراجها".

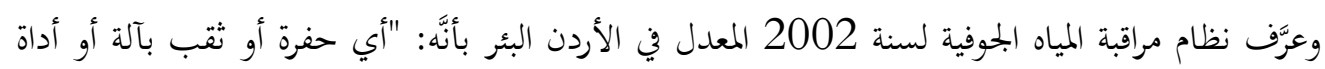

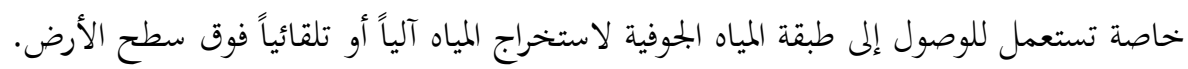

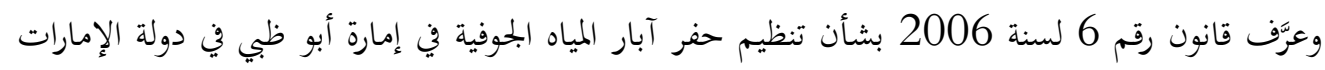

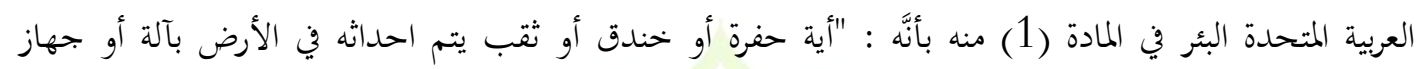
للوصول إلى المياه الجوفية واستخراجها.

\section{المبحث الثاني: أحكام حفر الآبار وآثارها في الفقه الإسلامي}

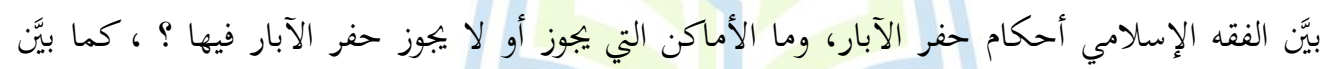

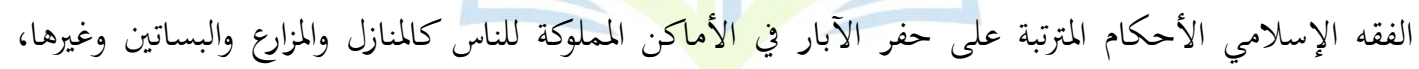

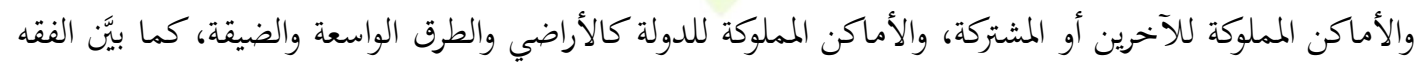

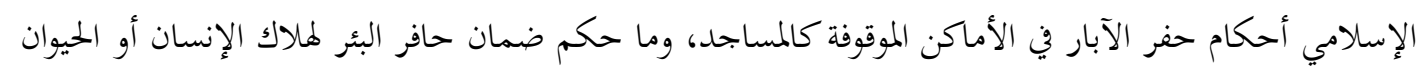

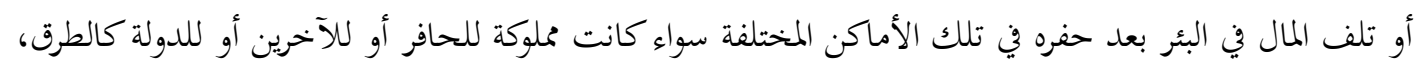
وهذا ما سنبينه في هذا المبحث عن طريق المطالب الآتية.

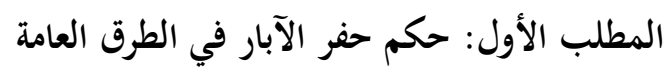

1 - نشرت تعليمات حفر الآبار المائية رقم 1 لسنة 2011 في الوقائع العراقية بالعدد (4201) في 1/ 8/ 2011. 72

Doi:10.37940/RJIS. 2021.2.1.3 
دعا الإسلام إلى حفر الآبار في الطرق العامة وبيَّن فضل ذلك، والثواب الكبير لمن يتولى حفرها؛ لمال هذه

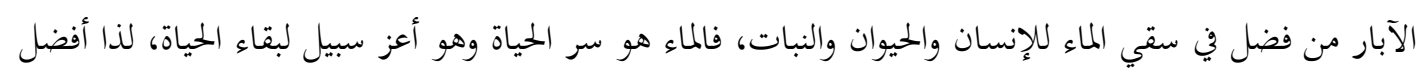

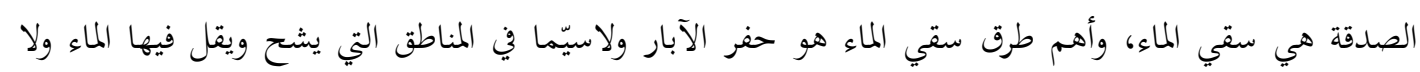

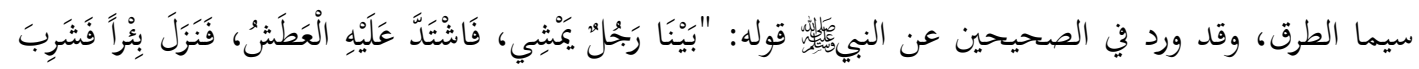

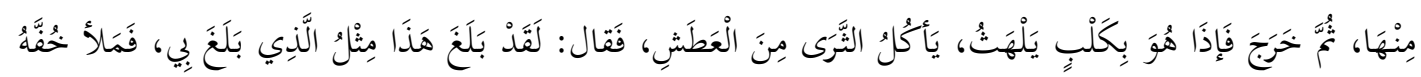

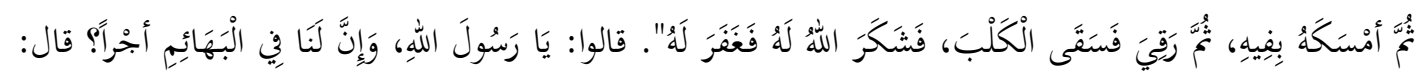

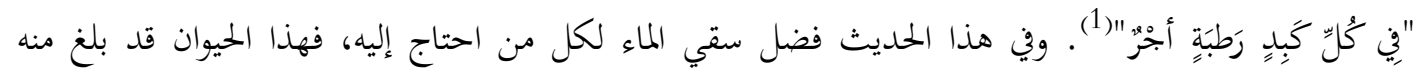

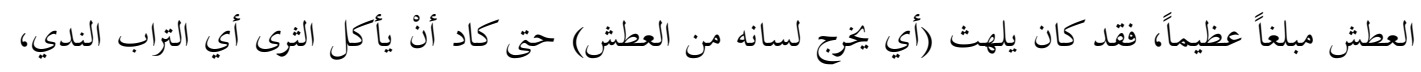

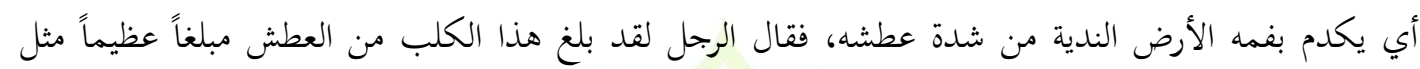

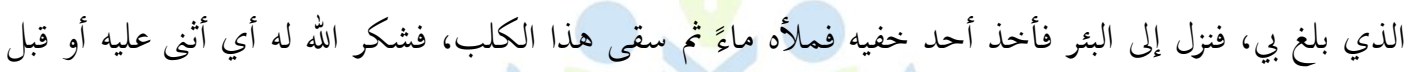

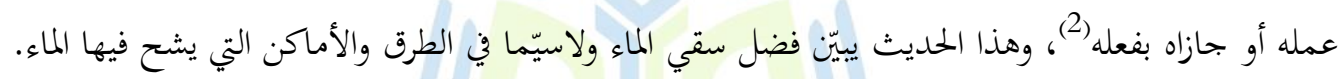

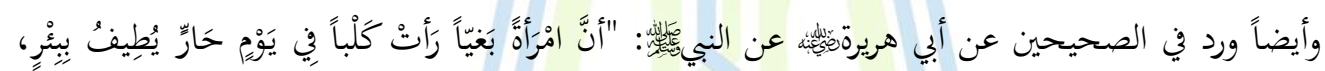

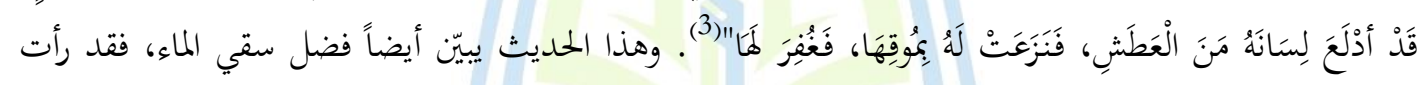

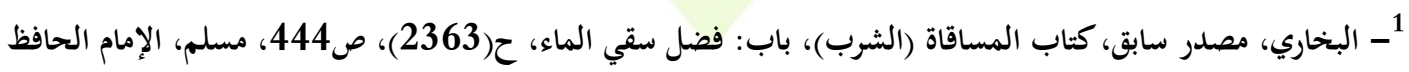

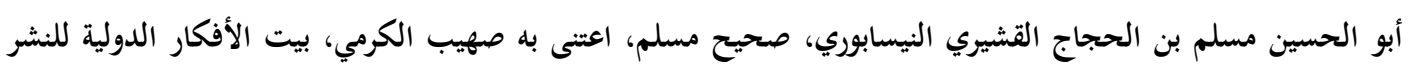

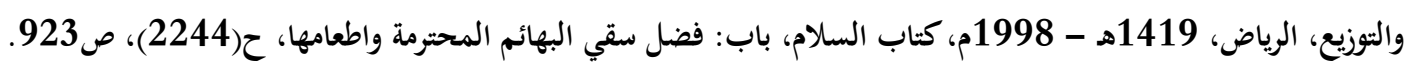
واللفظ للبخاري.

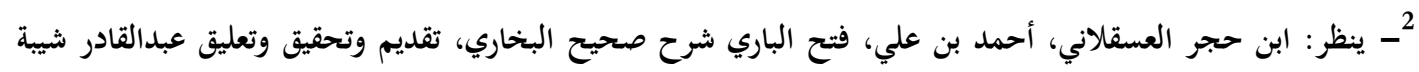

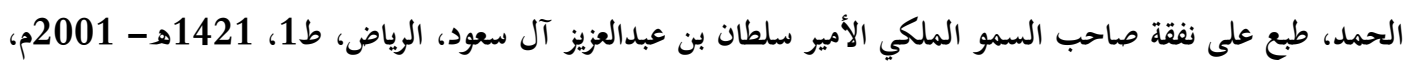

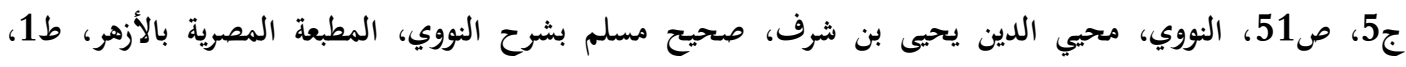

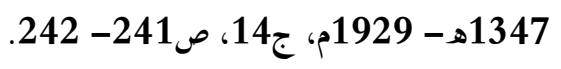

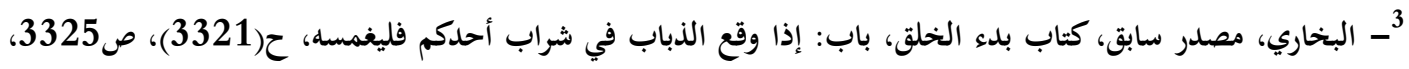

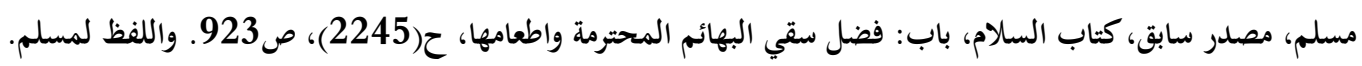
73

Doi:10.37940/RJIS. 2021.2.1.3 
امرأة بغي (أي زانية) كلباً يطوف حول البئر قد بلغ منه العطش مبلغاً عظيماً حتى أنَّهَ إذا دار حول البئر أدلع لسانه

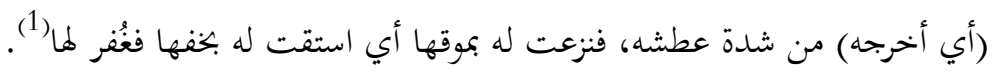

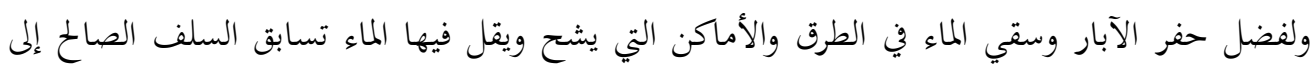

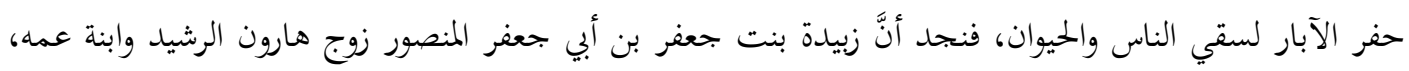

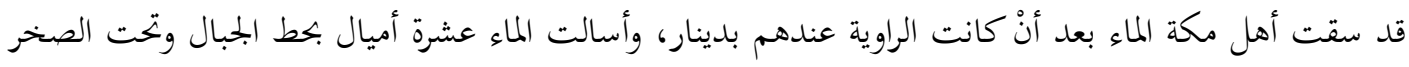

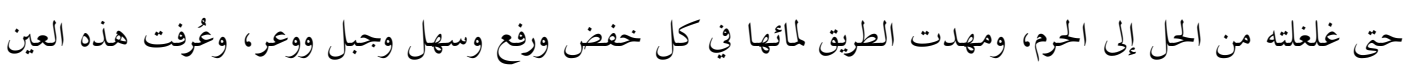

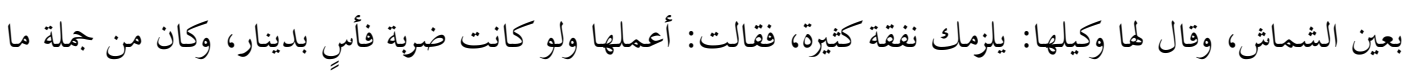

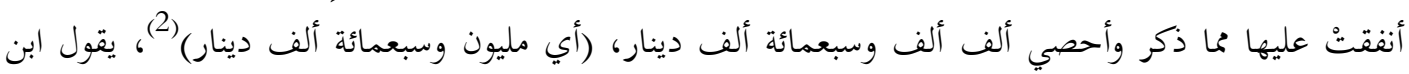

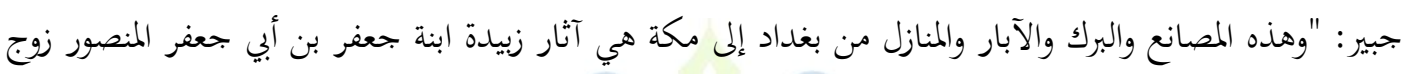

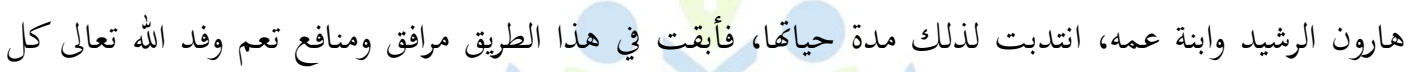

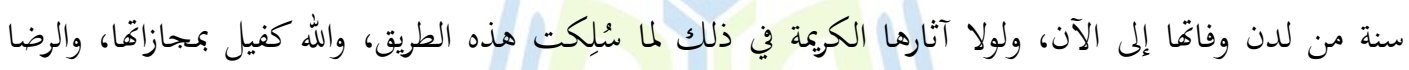
عنها" (3)

وعلى الرغم من فضل حفر الآبار في الطرق العامة وأهيته لا يخلو الأمر من خلاف بين الفقهاء في حكم

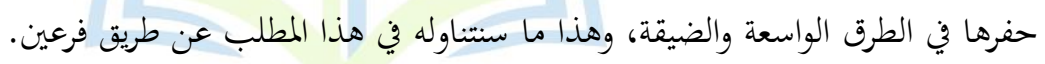

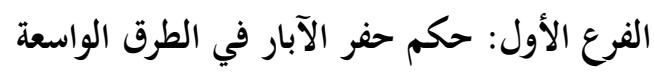

1 - ـ ينظر: النووي، مصدر سابق، ج14، ص242.

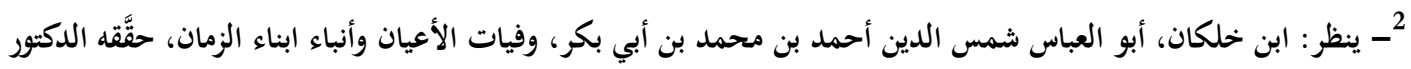

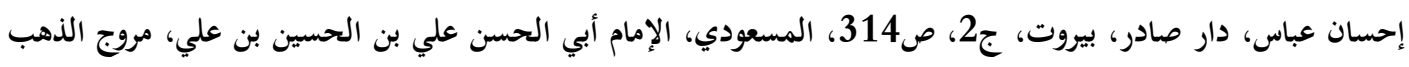

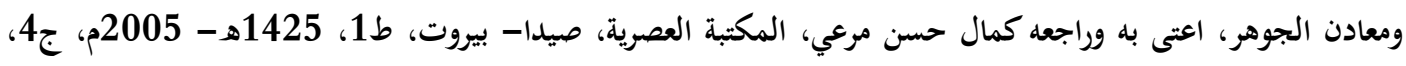

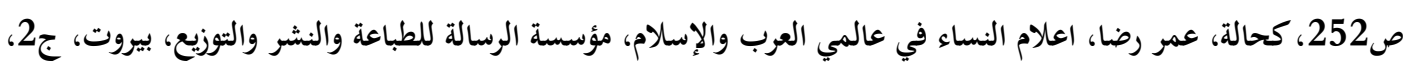
3- ابن جبير، أبو الحسين محمد بن أحمد بن جبير الكناني الأندلسي الشاطبي البلنسي، رحلة ابن جبير، دار صادر، بيروت،

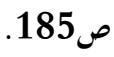


اختلف الفقهاء في حكم حفر الناس للآبار في الطرق الواسعة إذا كان ذلك بغير إذن الإمام أو ولي الأمر،

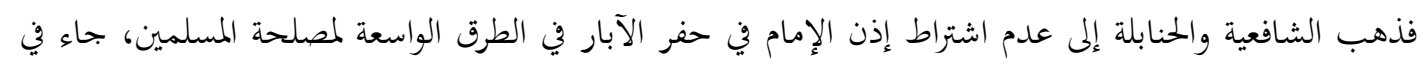
التحفة نقالًا عن الروض: "وله حفرها في الواسع لمصلحة المسلمين بلا ضمان وإنْ لم ئل يأذن الإمام" (1).

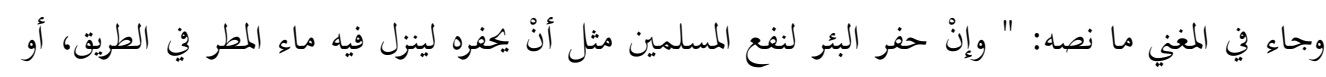

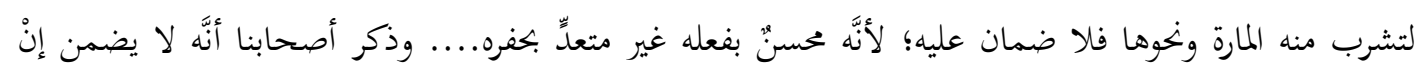

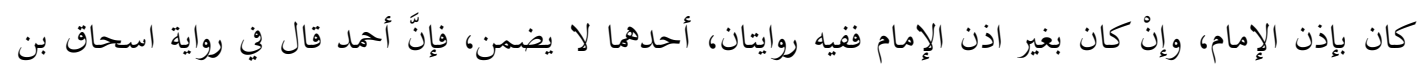

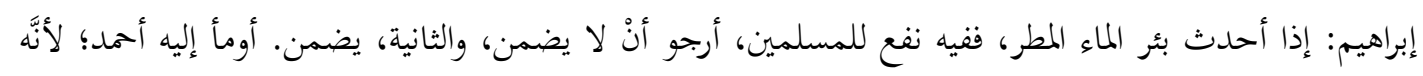

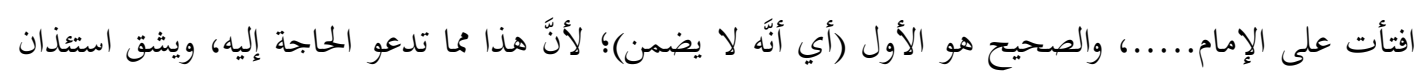

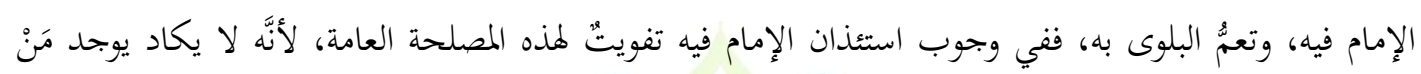

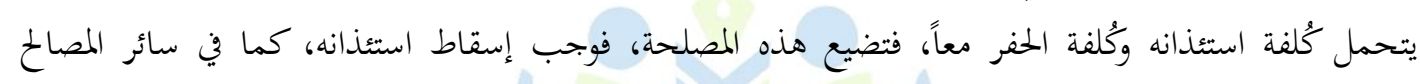
العامة").

إذن فالراجح عند الحنابلة أنَّ من حفر البئر في الطريق لا يضمن وإنْ لم يأذن الإمام بالحفر؛ لأنَّ حفر الآبار

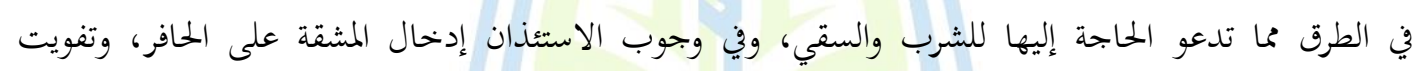
للمصلحة العامة وإضاعة لها.

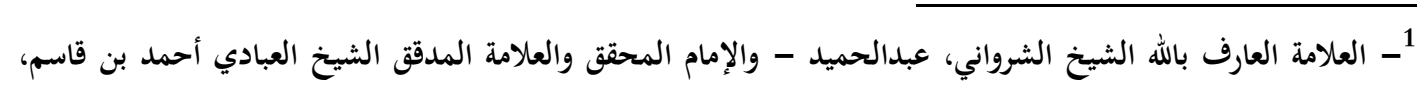

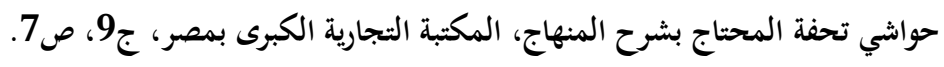

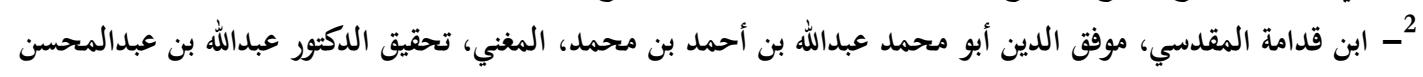

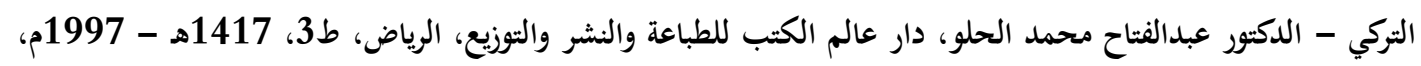

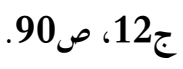


ومع هذا ذهب الحنابلة إلى أنَّهَ إذا كان الطريق واسعاً فحفر في مكان منها بئراً يضر بالمسلمين، فعلى الحافر

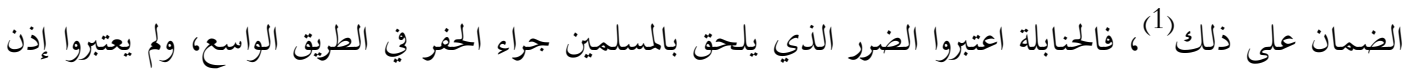
الإمام في الحفر من عدمه.

لكنّه يجاب على ما ذهب إليه الشافعية والحنابلة بأنَّ الإمام هو الذي له الولاية العامة على المسلمين، فهو

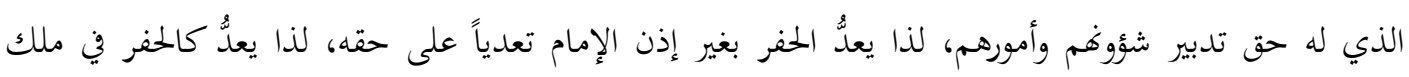

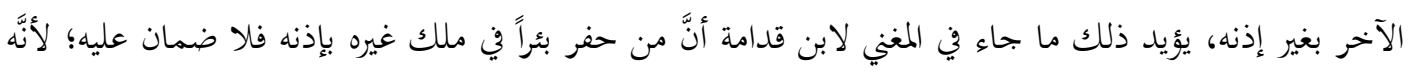

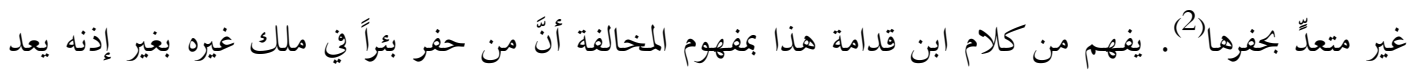

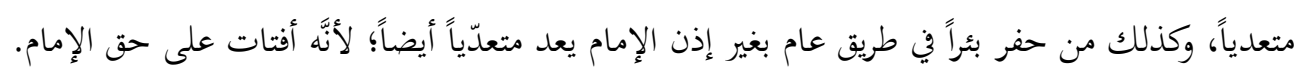

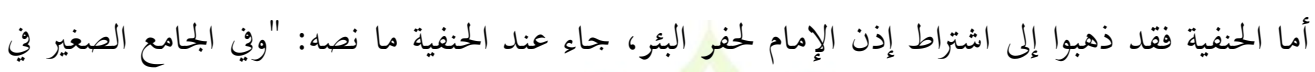

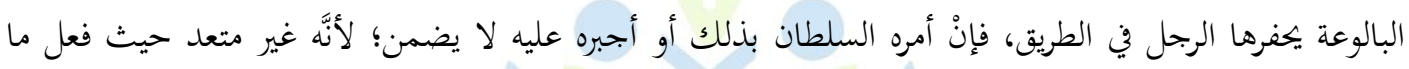

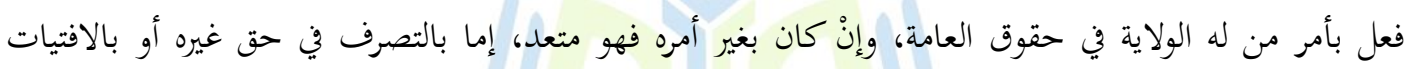
على رأي الإمام"(3). والذي أراه راجحاً ما ذهب إليه الحنفية من اشتراط إذن الإمام أو ولي الأمر أو صاحب السلطة في منح

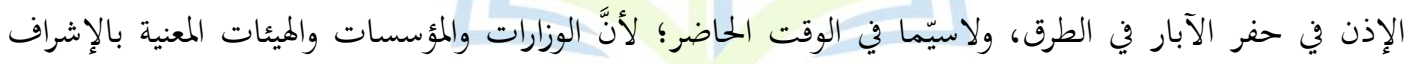

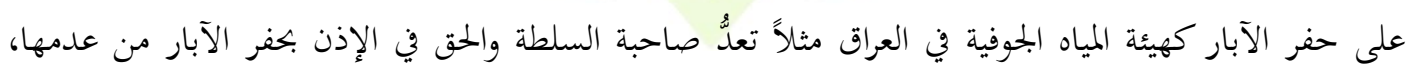

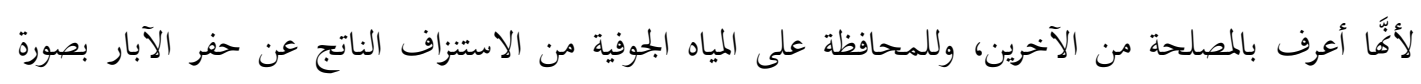

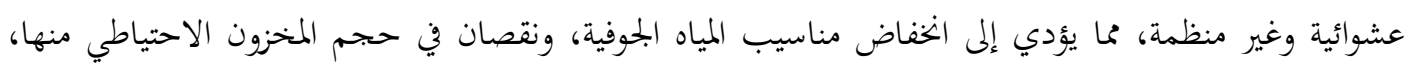

$$
\begin{aligned}
& \text { 1- ينظر: المصدر نفسه، ج12، ص89-80 } 90 .
\end{aligned}
$$

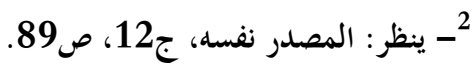

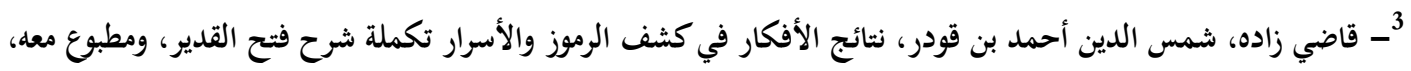

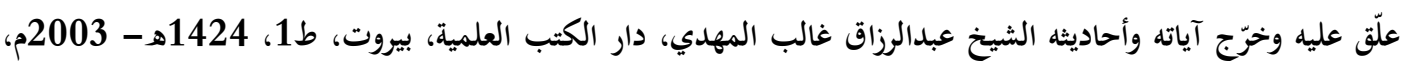

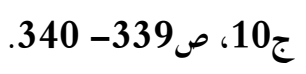


ولاسيّما أنَّ العالم اليوم يواجه أزمة شحة المياه ونقصها، أو يكون حفر الآبار من قبل الناس بصورة غير صحيحة،

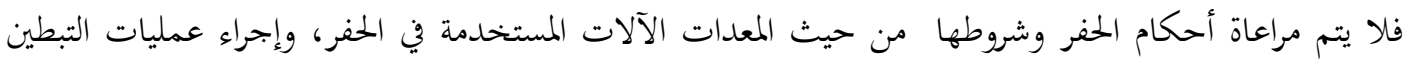

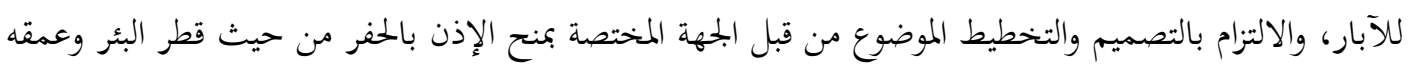

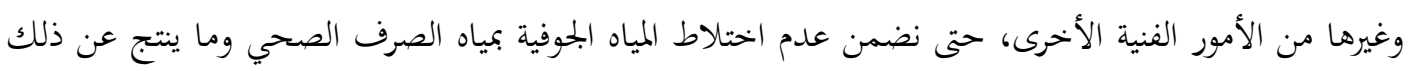

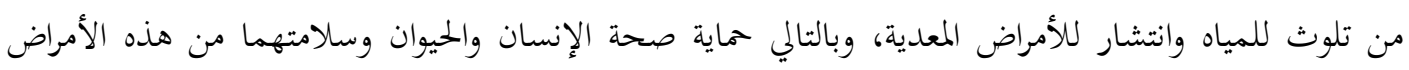
النابحة عن تلوث المياه، والله تعالى أعلم.

\section{الفرع الثاني: حكم حفر الآبار في الطرق الضيقة}

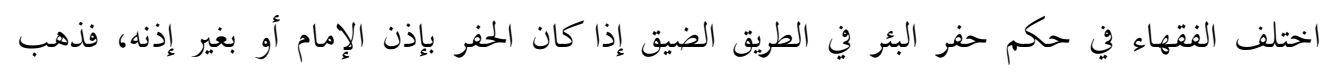

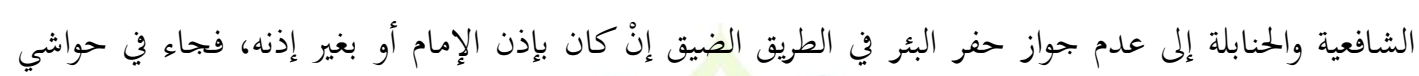

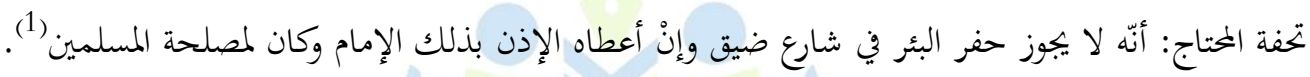

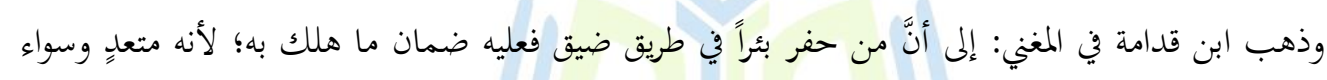

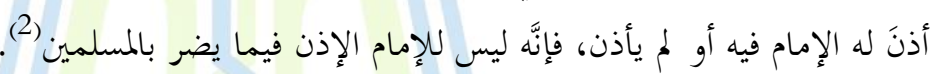

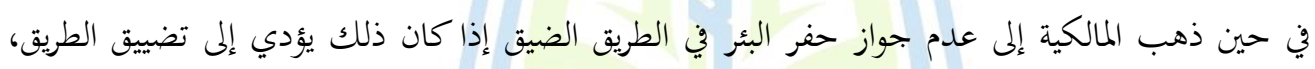

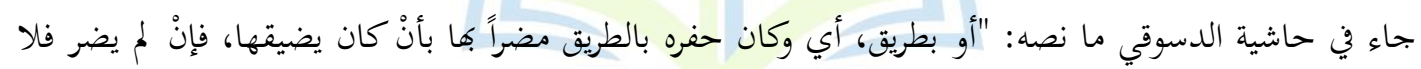

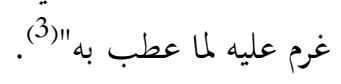

فالمالكية إذن لم يشترطوا إذْنَ الإمام من عدمه في حفر البئر في الطريق الضيق، وإنما اشترطوا في جواز حفر

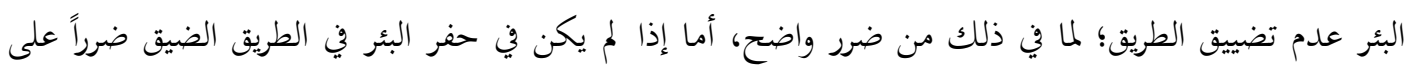

$$
\begin{aligned}
& \text { 1- ينظر: الشرواني- العبادي، مصدر سابق، ج9، ص7. }
\end{aligned}
$$

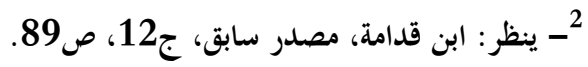

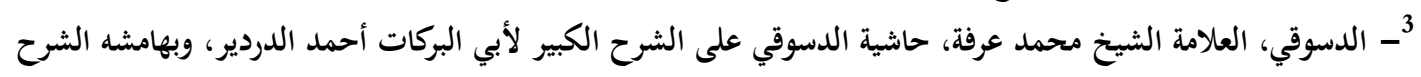

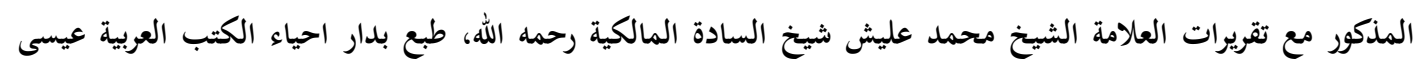

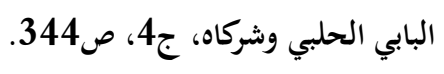


الناس فلا مانع عندهم في حفرها، بدليل أهم لم يضمنوا من حفرها إذا عطب، أو هلك، أو تلف، في البئر إنسان، أو حيوان، أو مال.

ولم أجد للحنفية قولاً في حفر البئر في الطريق الضيق برغم البحث والتقصي في المصادر التي اطلعت عليها،

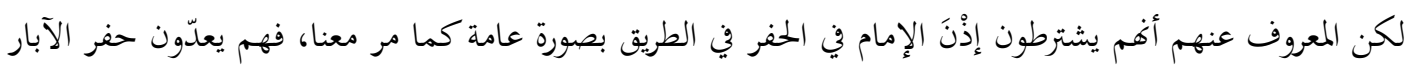

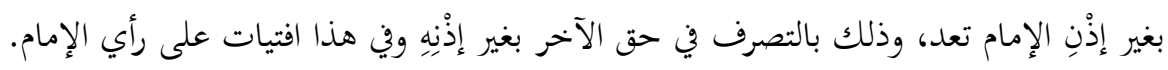

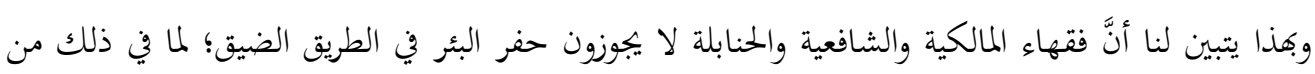

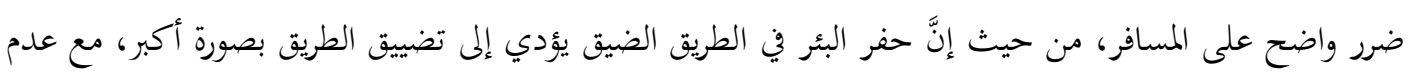

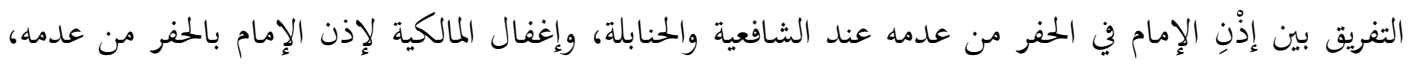

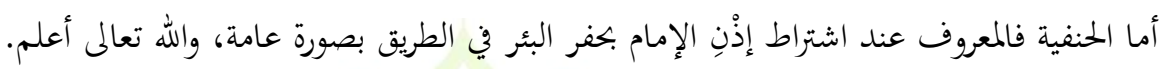

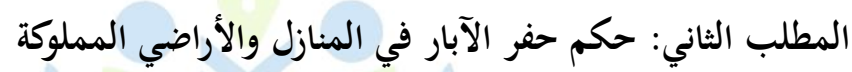

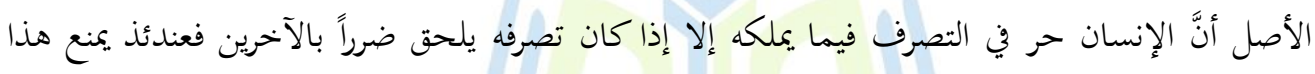

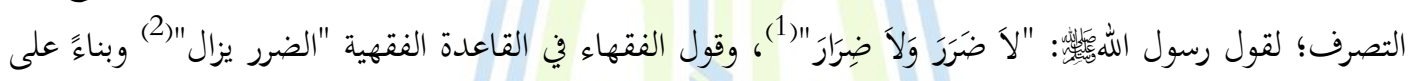

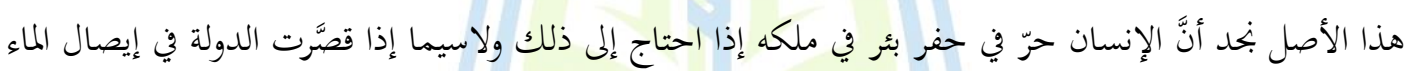

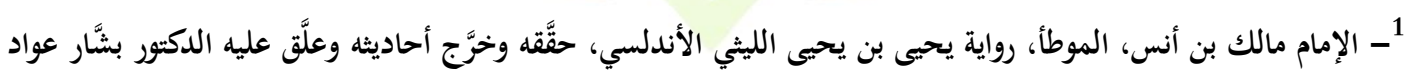

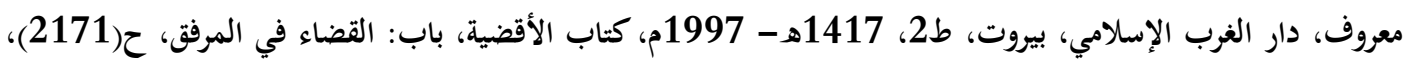

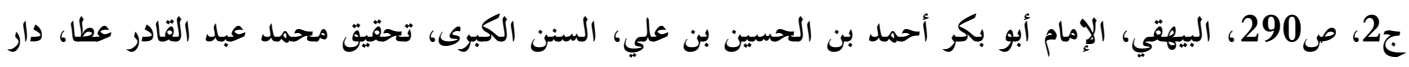

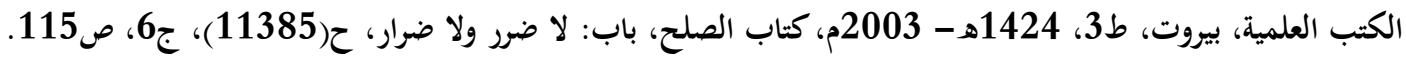

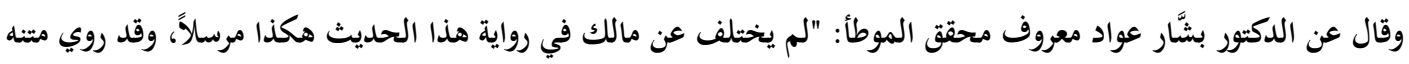

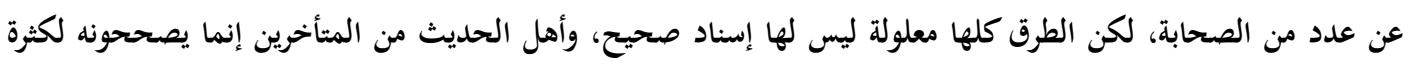

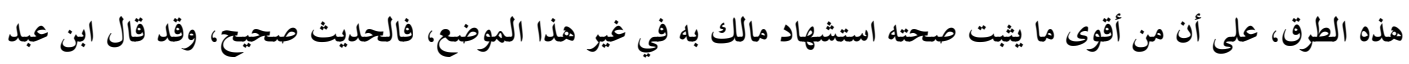

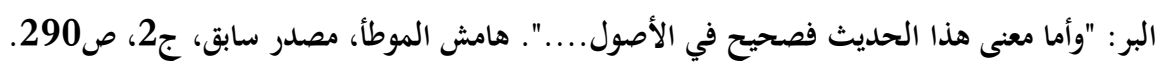

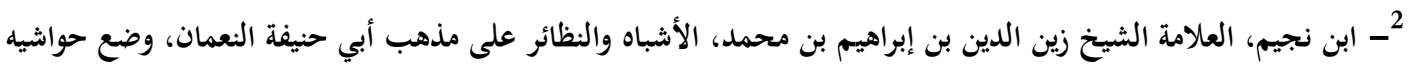

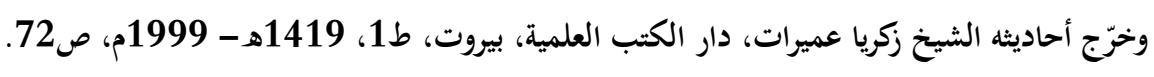


إلى المنازل والأراضي المملوكة للناس، أو كانت هناك شحة في المياه المزودة للمنازل والأراضي المملوكة للناس، فلا

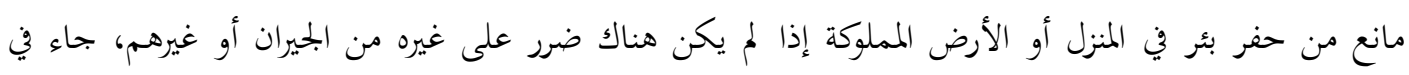

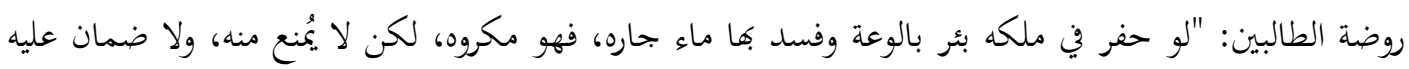
بسببه على الصحيح" (1).

وهذا يدل على جواز حفر بئر أو بالوعة في الملك لحاجة، ومما يدل على جواز حفر الآبار لاستخراج المياه

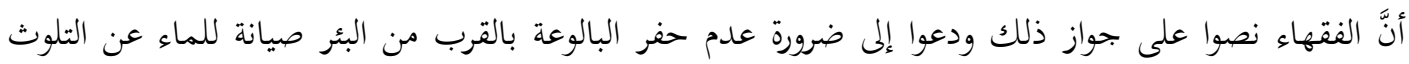

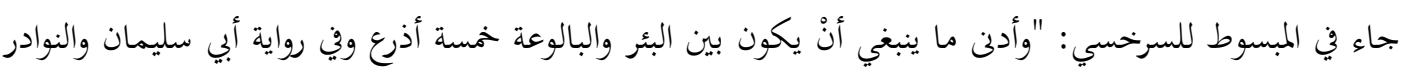

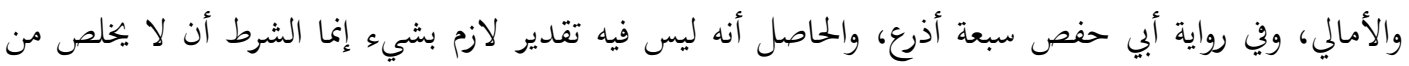
البالوعة والبئر شيء، وذلك باختلاف الأراضي في الصلابة والرخاوة....."(2.).

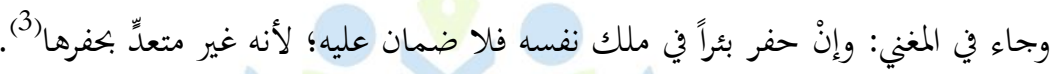

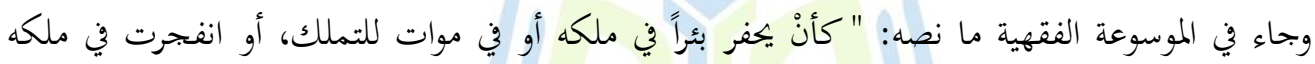
عين، فإنه يملك الماء؛ لأنه نماء كالثمرة واللبن" (4). ومن الفتاوى المعاصرة في حكم جواز حفر بئر في أرض المنزل لشح المياه، وإهمال الدولة في إيصال الماء كان المان

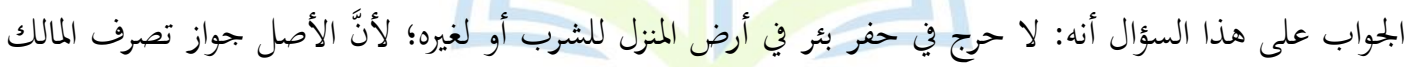

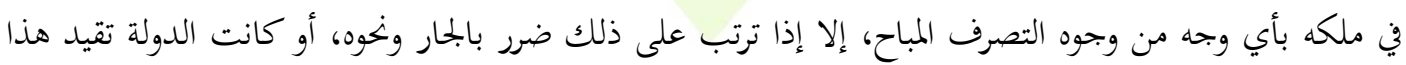
المباح فتمنع من إحداث ذلك لدفع مفسدة عامة مثلاً، فيلزم حينئ مراعاة ذلك المنع وعدم بحاوزه (5).

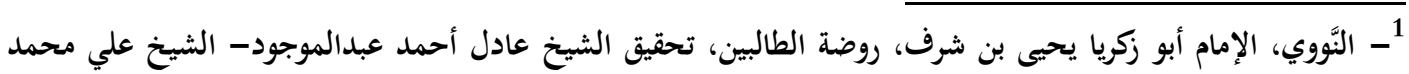

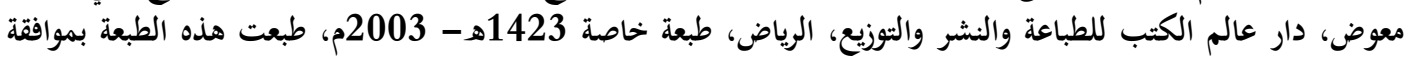

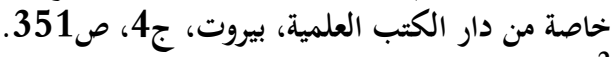

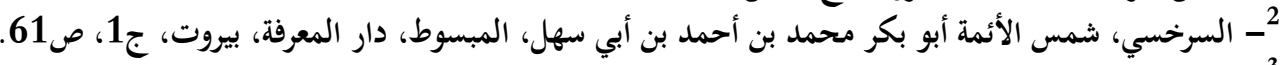

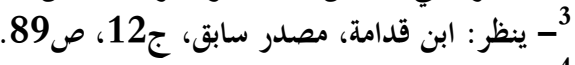

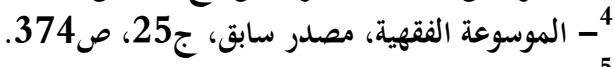
5 5 ينظر: الفتوى المنشورة على الرابط التالي:

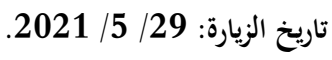


يتبين لنا مما تقدم جواز حفر الآبار في المنازل والأراضي المملوكة للناس إذا احتاجوا إلى ذلك لشح المياه أو

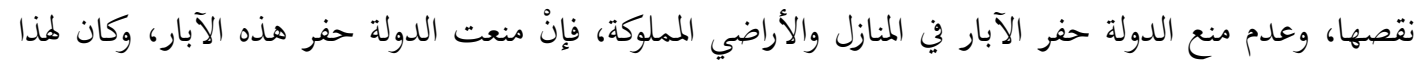

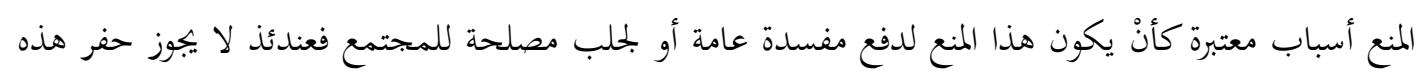
الآبار، والله تعالى أعلم.

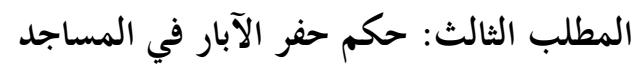
اتفق الحنفية والمالكية والحنابلة على عدم جواز حفر الآبار في المساجد، أما الشافعية والحنابلة في قول لهم المباجل

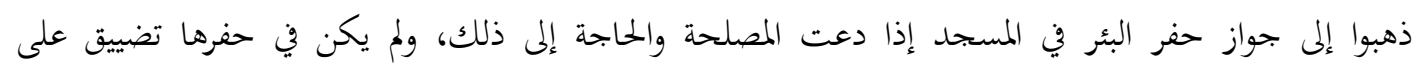
المصلين، ولم يترتب على حفرها مفسدة، وفيما يلي أقوال الفقهاء في هذه المسألة:

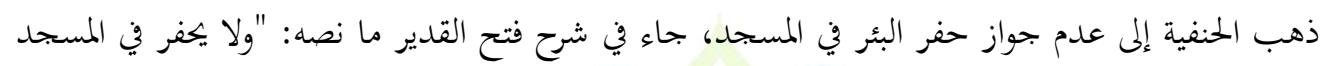

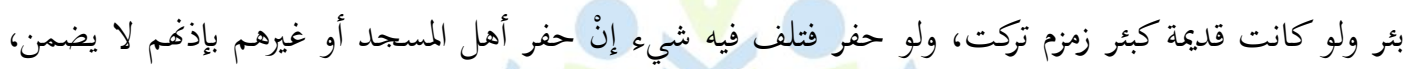
وإن كان بغير اذغهم ضمن أضر ذلك بأهله أو لا" (1). كذلك ذهب المالكية إلى عدم جواز حفر الآبار وغرس الأشجار وغيرها من الأفعال في المسجد، فإنْ حدث ذلك قلع (2). أما الحنابلة فقد حرَّموا حفر الآبار وغرس الأشجار في المساجد؛ " لأنَّ البقعة مستحقة للصلاة فتعطيلها

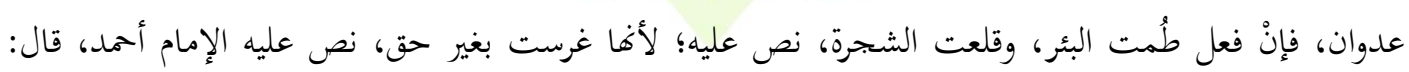

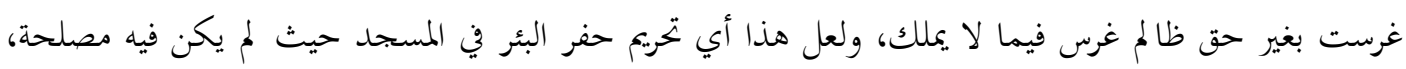

1- ابن الهمام الحنفي، الثيخ الإمام كمال الدين محمد بن عبدالواحد السيواسي، شرح فتح القدير مع تكملته نتائج الأفكار

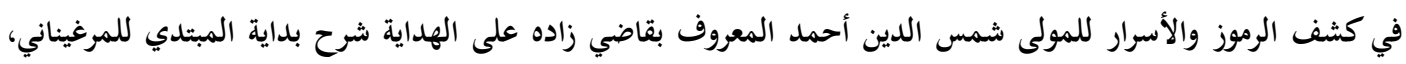

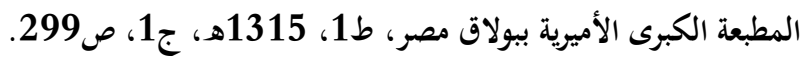

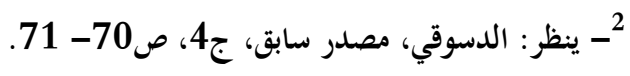


قال في الاقناع: ويتوجه جواز حفر بئر إن كان فيه مصلحة ولم يحصل به ضيق. قال في الرعاية: لم يكره أحمد

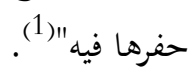

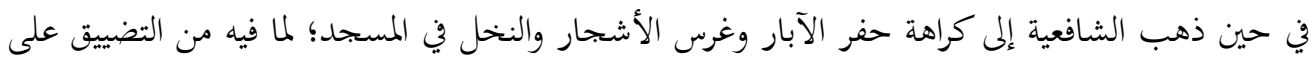

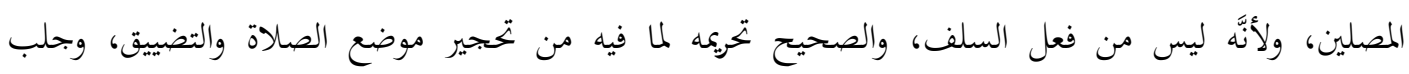

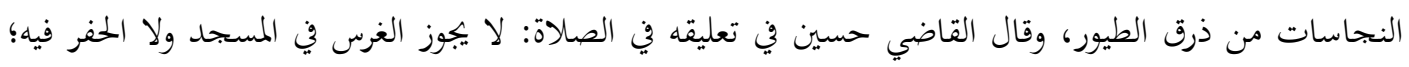

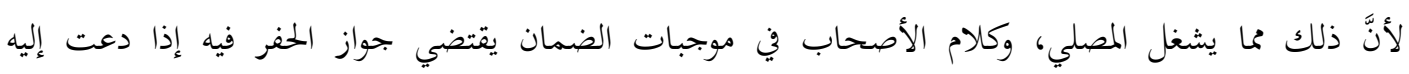
ضرورة)

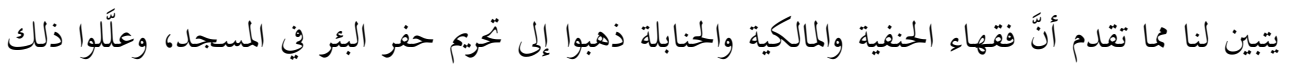

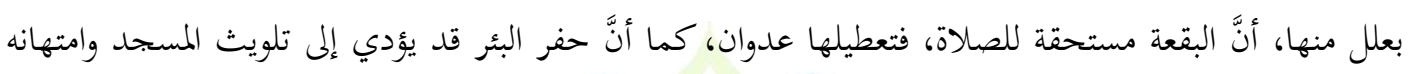

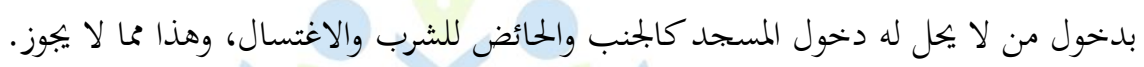

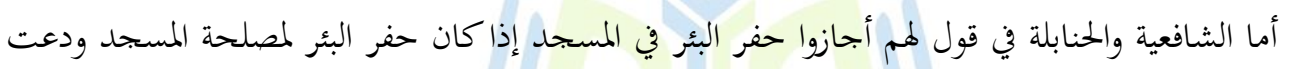

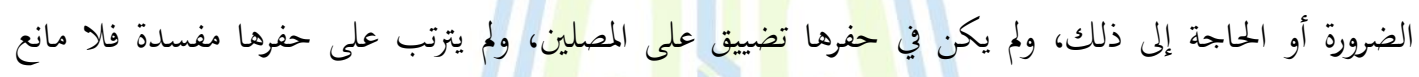

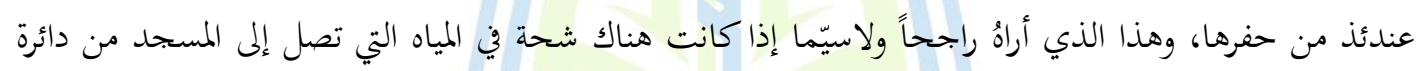

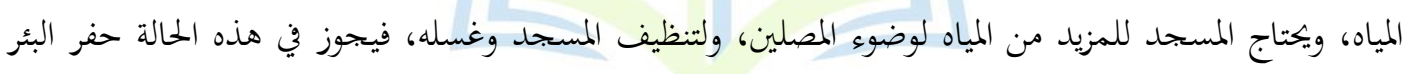
في المسجد، والله تعالى أعلم. المطلب الرابع: حكم حفر الآبار من أموال الزكاة

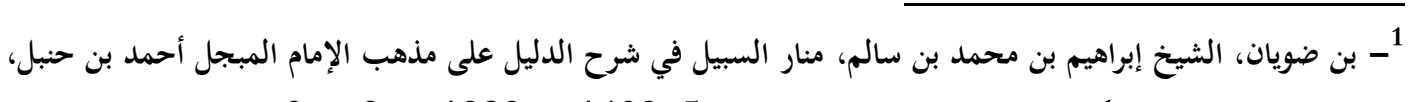

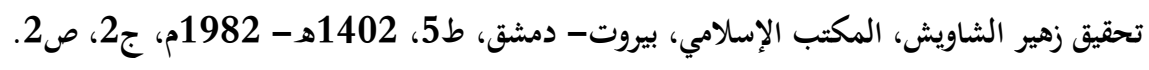

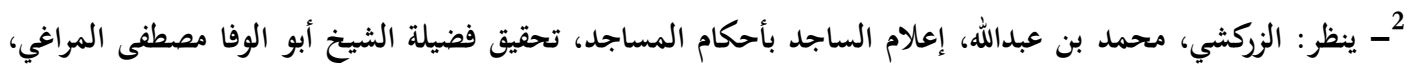

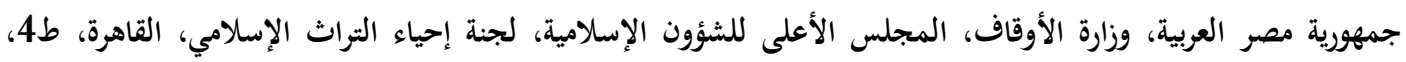

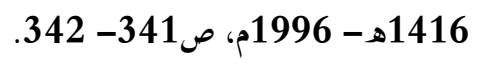
81

Doi:10.37940/RJIS. 2021.2.1.3 
لا شك أنَّ سقي الماء من أفضل الأعمال والصدقات، والإسلام دعا أهل الغنى والمال للتبرع بحفر الآبار،

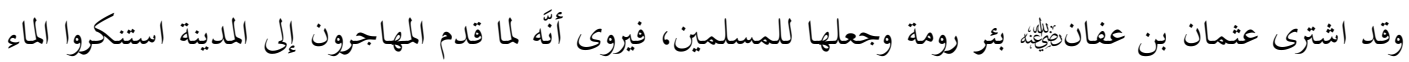

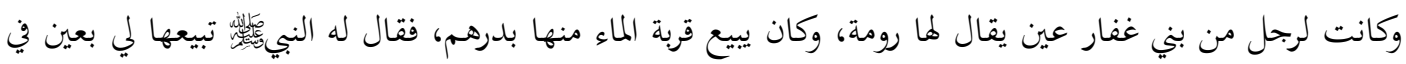

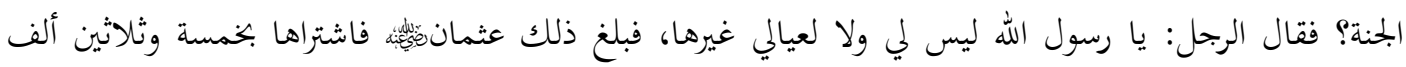

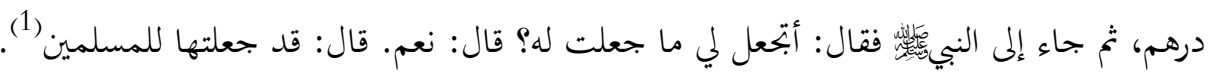

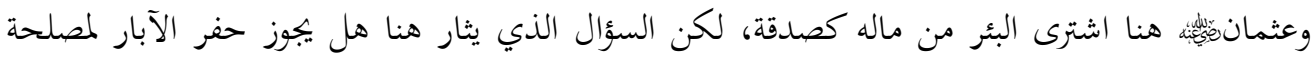

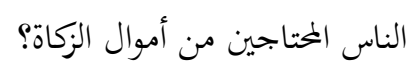

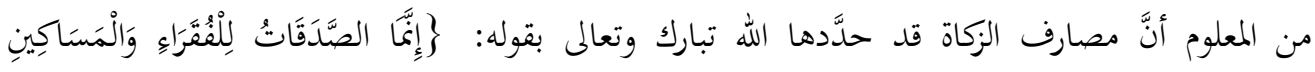

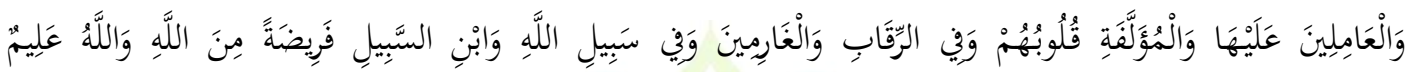

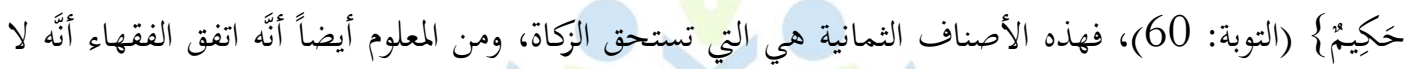

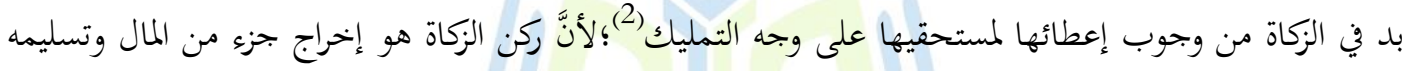

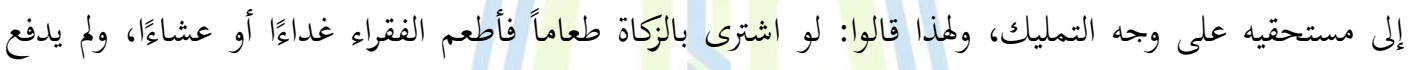

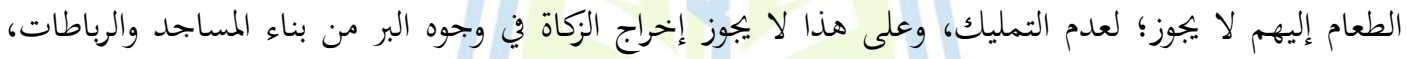

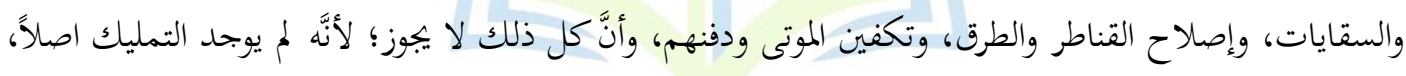

1 - ـ ينظر : ابن حجر العسقلاني، مصدر سابق، ج5، ص478.

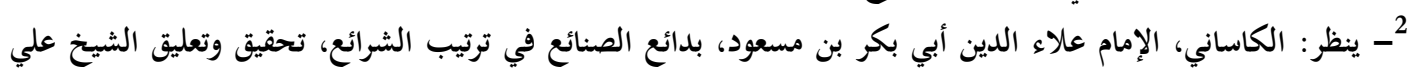

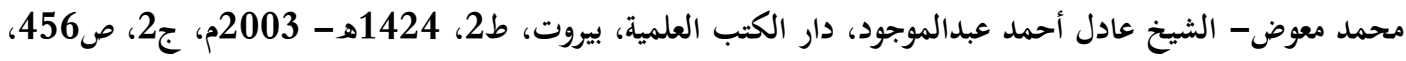

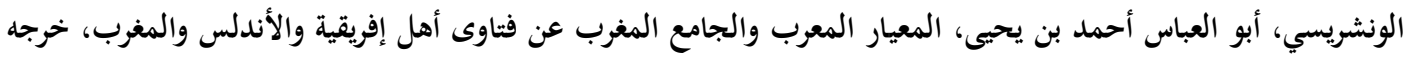

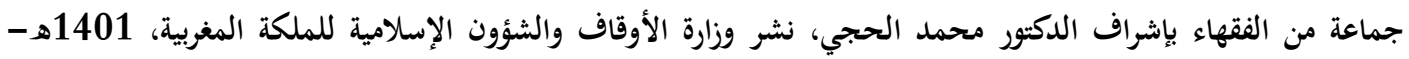

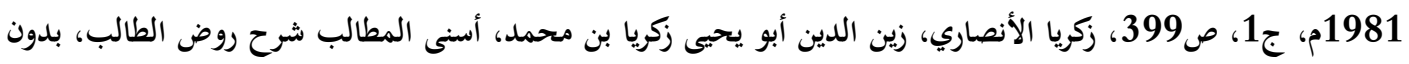

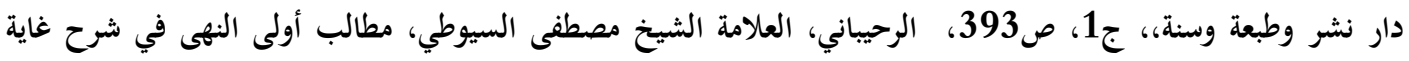

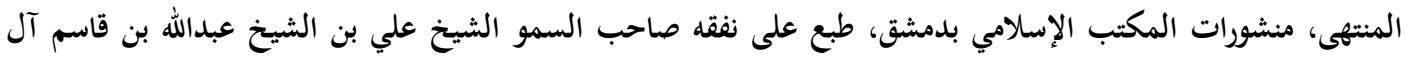

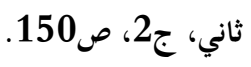


فلا بد إذن من تمليك الزكاة لمستحقيها وإعطائها بأيديهم أو بيد من ينوب عنهم وهو المصدق (1)، وإذا كان المدفوع إلمان

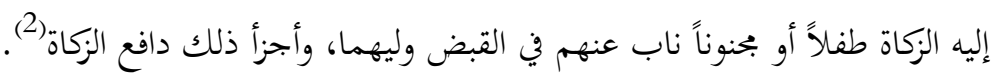

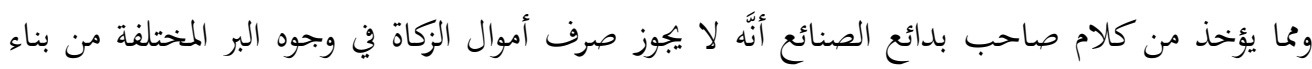

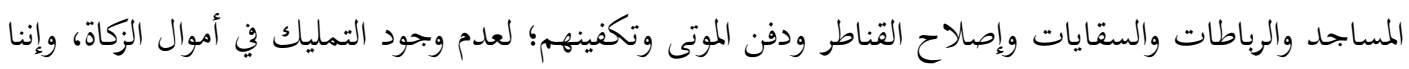

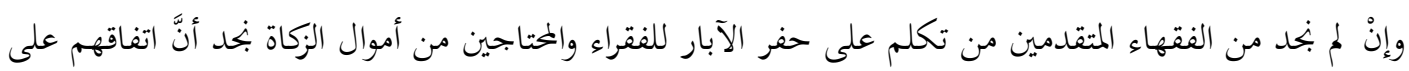

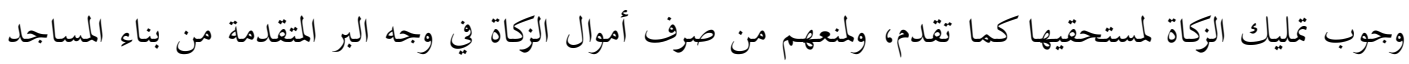

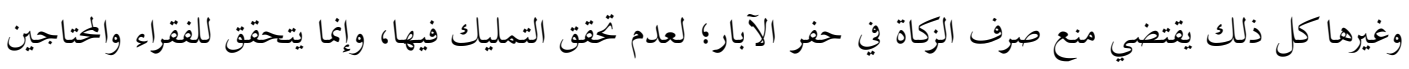

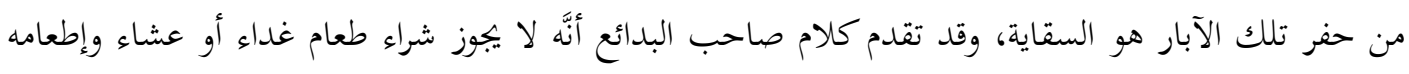

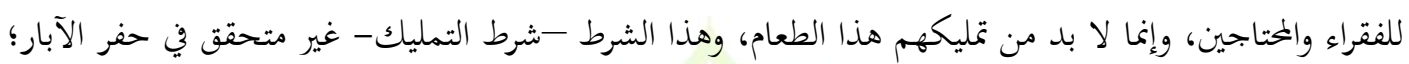

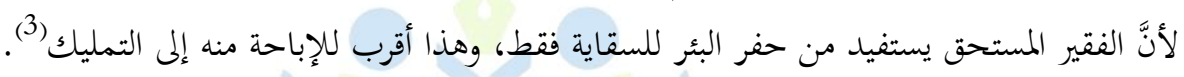

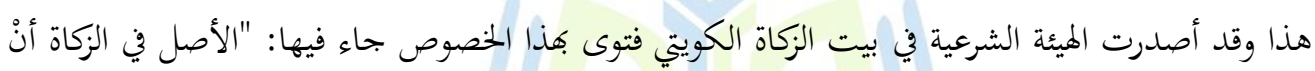

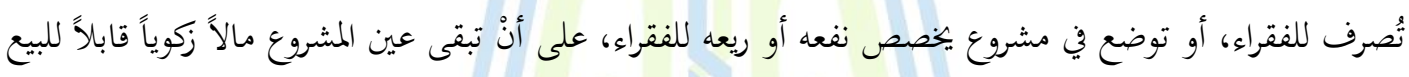

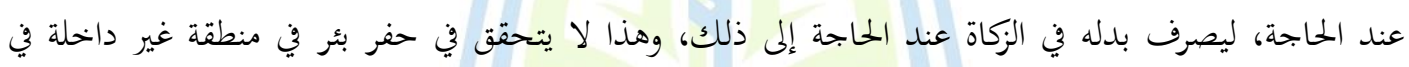

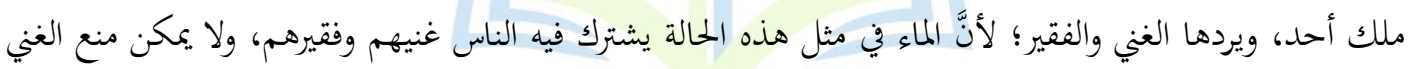

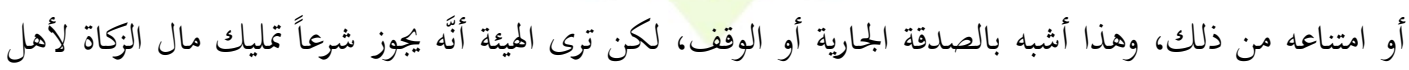
المنطقة الفقراء، ثم يوجهون إلى وضعه في حفر بئر يبيحون الانتفاع بها لهم ولغيرهم (4).

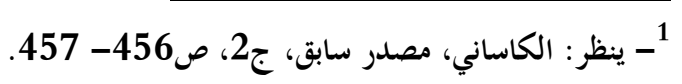

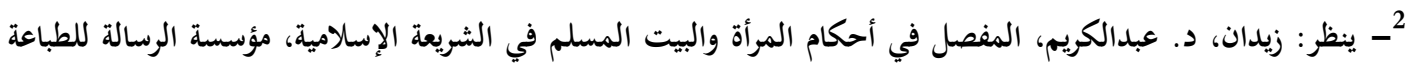

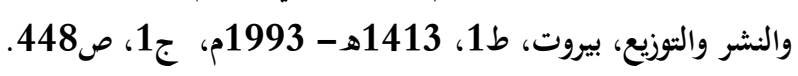

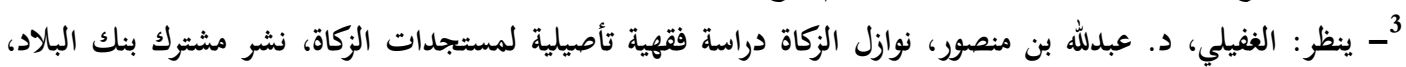

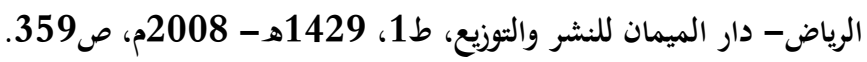

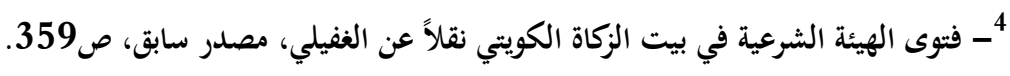


ورأى الدكتور عبدالله بن منصور الغفيلي لجواز حفر البئر من مال الزكاة أنَّهُ لا بد أنْ يكون بحسب الضوابط الآتية) (1)

$$
\text { 1- - أنْ تكون الحاجة إلى حفر البئر ظاهرة. }
$$

2- أنْ يغلب على الظن استسقاء واستفادة الفقراء من ماء البئر دون غيرهم من الأغنياء، كما لو لو لواهر

كان البئر في منطقة خاصة بالفقراء والمختاجين.

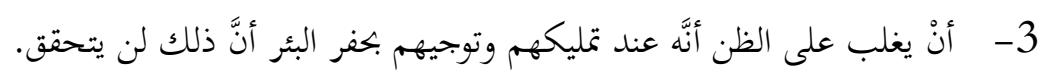

$$
\text { 4- ألّا يمكن حفر البئر من مال غير مال الزكاة. }
$$

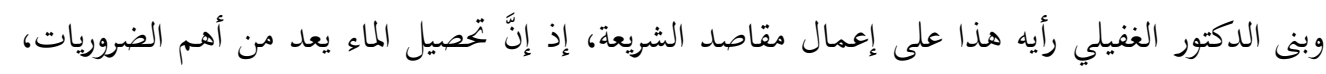

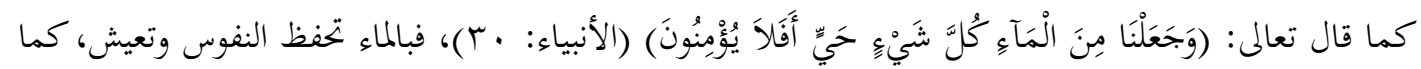

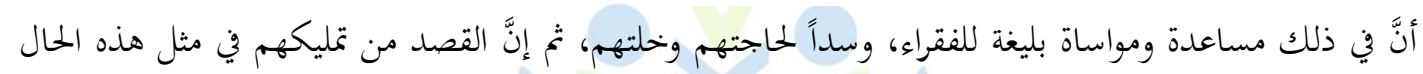

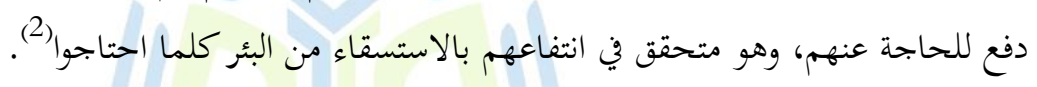
في حين ذهب فقهاء معاصرون في فتاويهم إلى عدم جواز حفر البئر من أموال الزكاة؛ لأنَّ الأصل في الزكاة

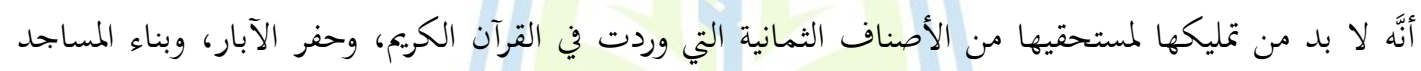

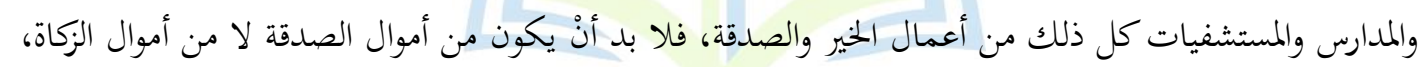

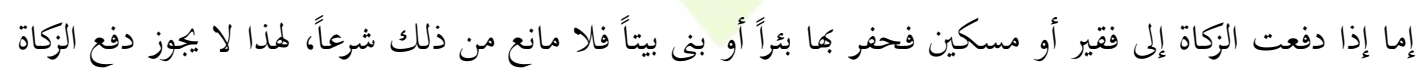

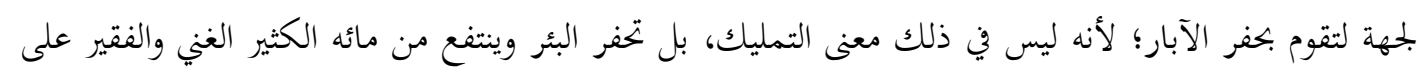

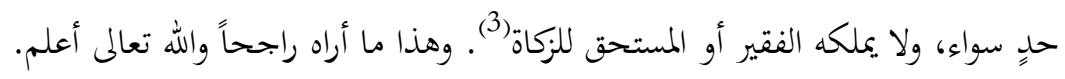
المطلب الخامس: حكم ضمان حافر البئر في الفقه الإسلامي

$$
\begin{aligned}
& \text { 1- ينظر : الغفيلي، مصدر سابق، ص360- } 361 .
\end{aligned}
$$

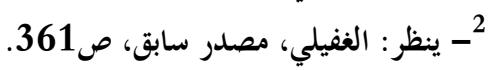

3- تنظر الفتوى على الرابط التالي: https:/2u.pw/wwKd1 تاريخ الزيارة: 29/ 29 / 2021. 
مذهب الحنفية أنَّهّ إذا حفر إنسانٌ بئراً في ملكه وهلك فيه أو تلف إنسان أو حيوان أو مال فلا شيء على الحكان

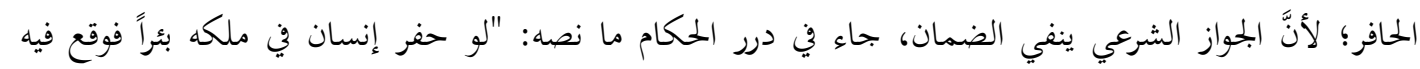

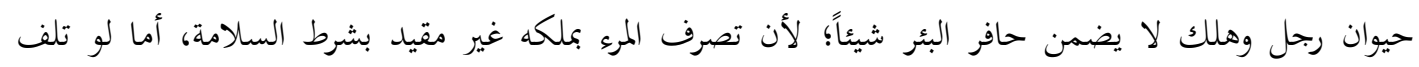

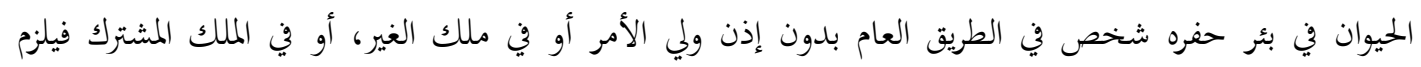

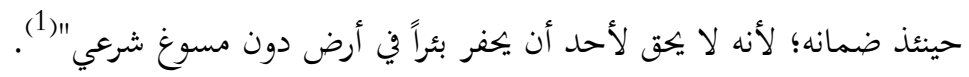

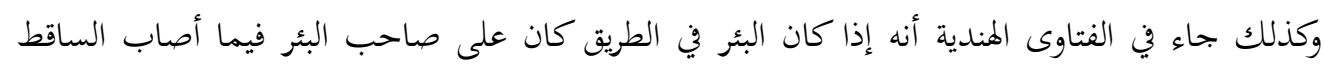

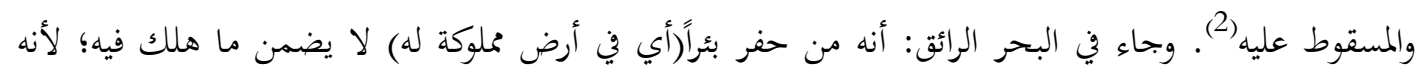

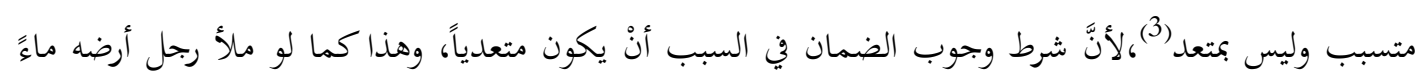

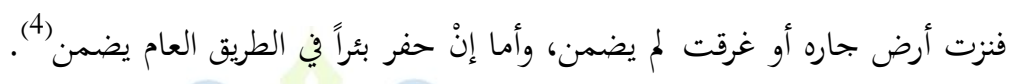

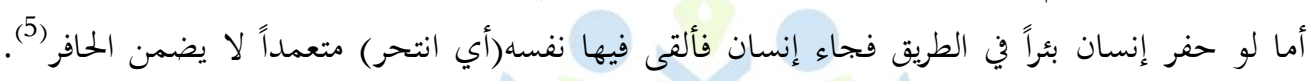

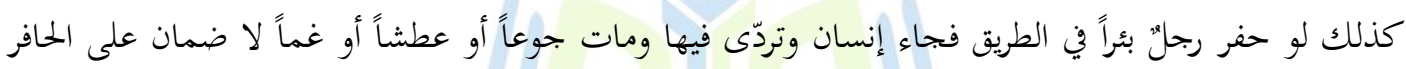
في قول الإمام أبي حنيفة (رحمه الله) (6).

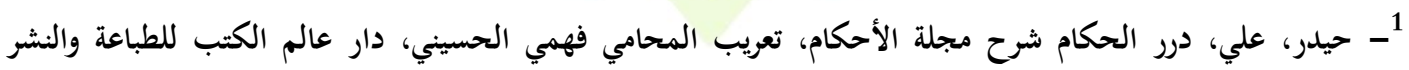

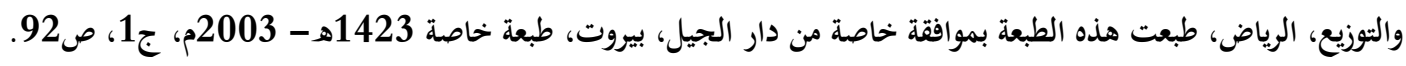

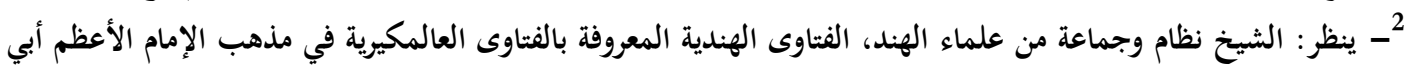

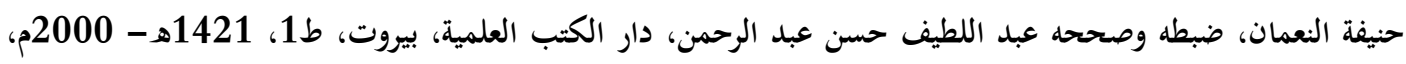

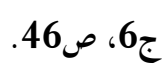

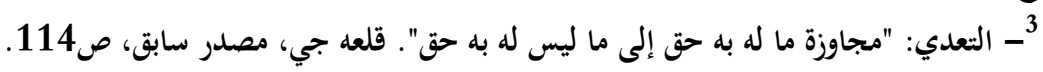

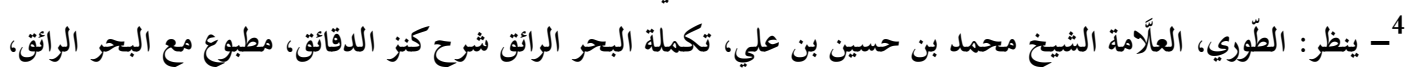

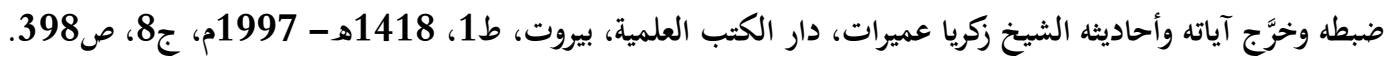

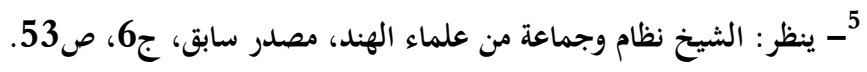
6- ينظر: المصدر نفسه، ج6، ص54. 
وكذا لو حفر رجلٌّ بئراً في المفازة في موضع ليس بممر ولا طريق لإنسان بغير إذن الإمام فوقع فيها إنسان لا

$$
\text { يضمن الحافر(1). }
$$

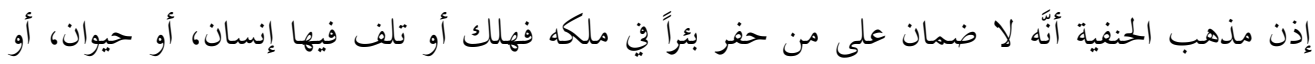

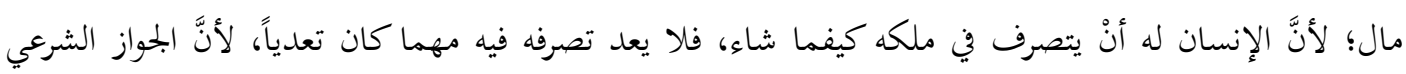

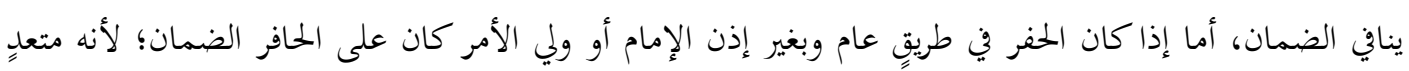
بفعله هذا، والمعتدي يضمن (2). أما مذهب المالكية، فقد ورد في مواهب الجليل ما نصه: "سألت ابن القاسم عن الرجل يكون له الزرع فتغير

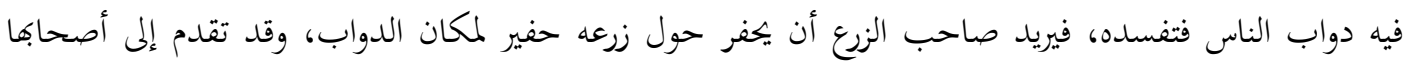

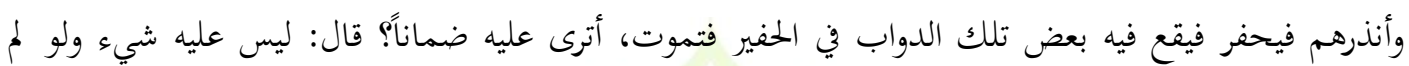

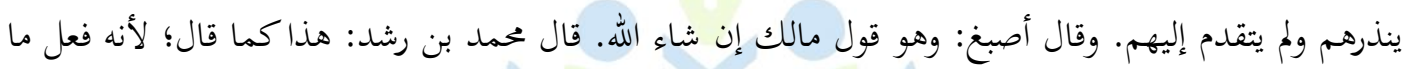

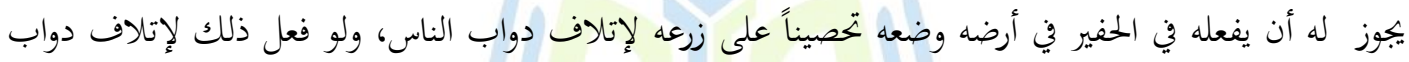

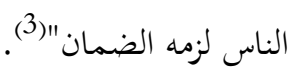

نستدل من كلام المالكية هذا أنَّ من حفر بئراً في ملكه لا ضمان عليه؛ لأنه فعل في ملكه ما يجوز له، فهو غير متعدٍ بفعله، وبالتالي فلا ضمان عليه.

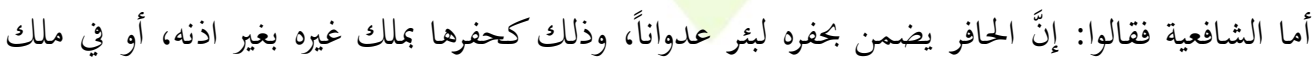

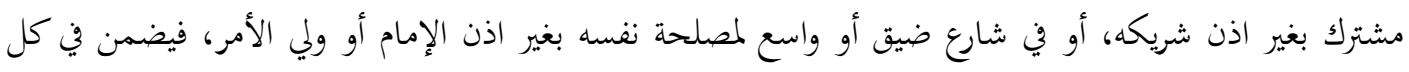

1 - ينظر: المصدر نفسه، ج6، ص54.

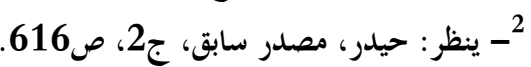

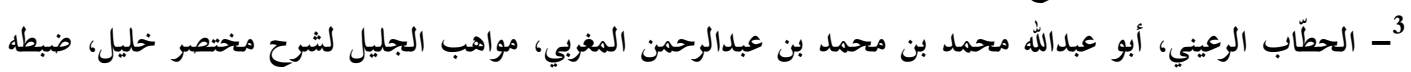

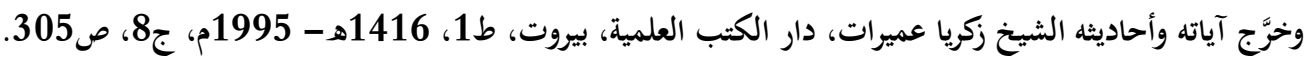


ذلك ما هلك أو تلف فيها من آدمي أو غيره، والآدمي يضمن بالدية على عاقلة الحافر حياً كان أو ميتاً، وأما غير

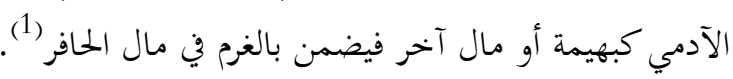

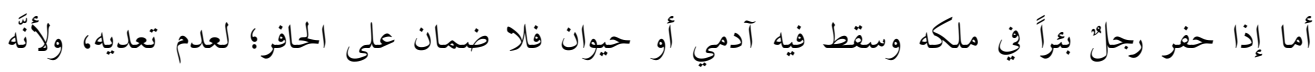
تصرف في ملكه فلا ضمان عليه (2). أما الحنابلة فقد اتفقوا مع المذاهب المتقدمة أنّه لا ضمان على من حفر بئراً في ملكه أو في ملك غيره بإذنه؛

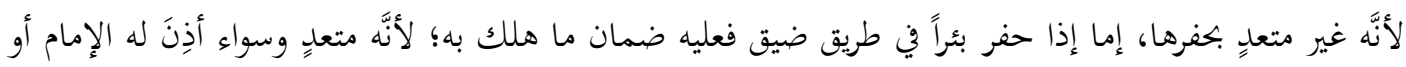

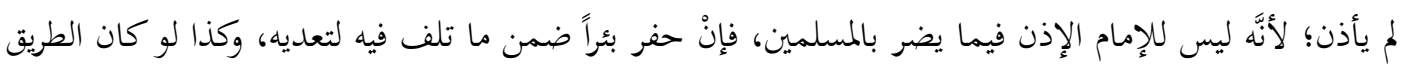

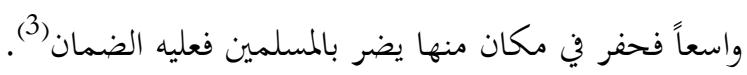

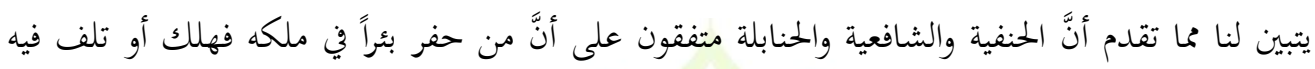

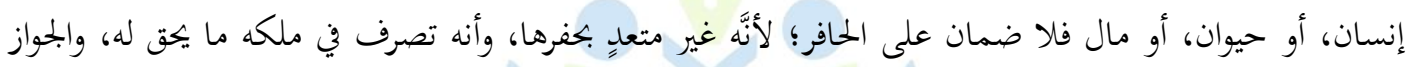

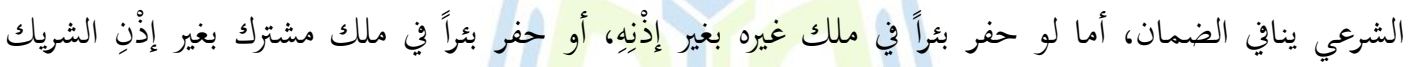

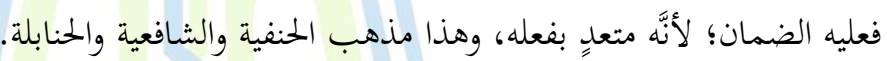

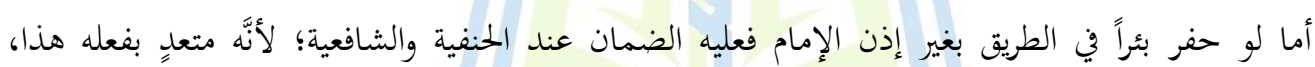

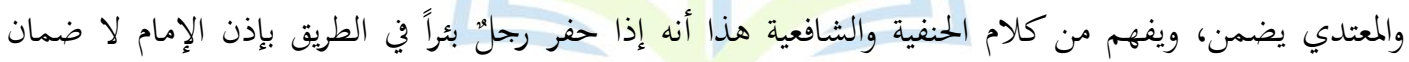

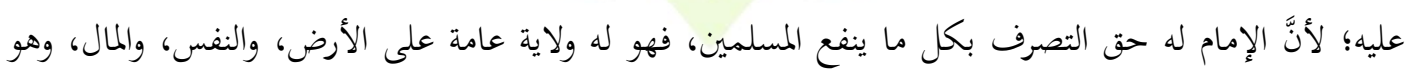

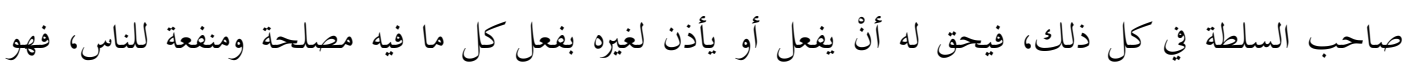

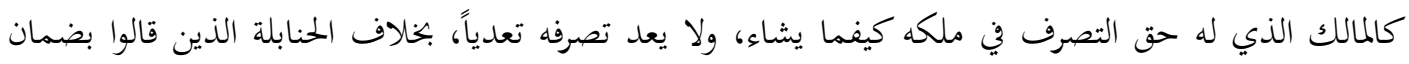

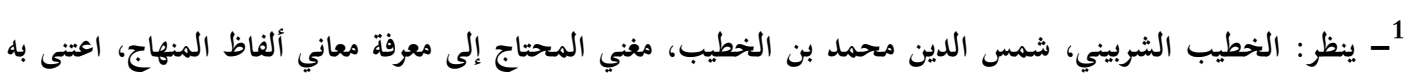

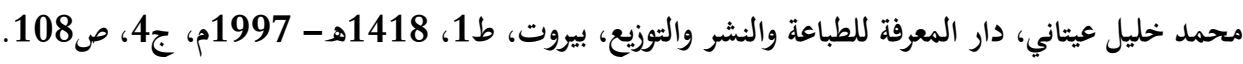

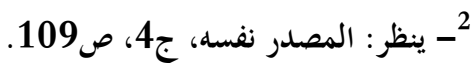

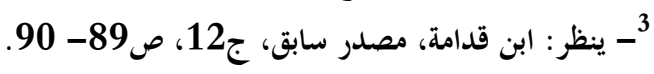


حافر البئر في الطريق إنْ هلك أو تلف فيها شيء وإنْ إذن الإمام له بالحفر؛ لأنه متعدٍ بحفره، ولأنّ الإمام ليس له

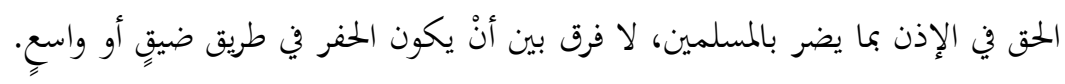

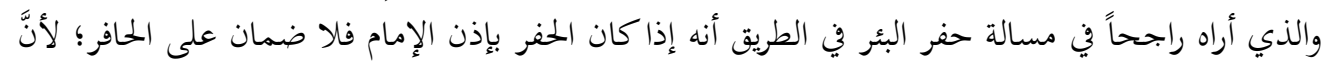

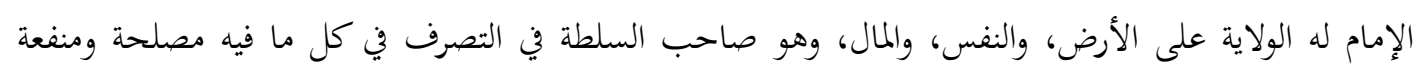

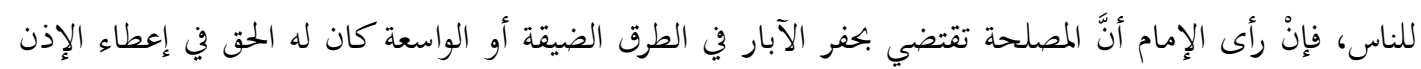
بحفر الآبار في الطرق تحقيقاً لمصلحة الناس ومنفعتهم في الشرب والسقاية من هذه الآبار والله تعالى أعلم.

\section{المبحث الثالث: أحكام حفر الآبار وشروطها وآثارها في القانون الوضعي}

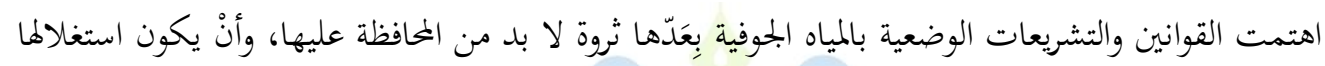

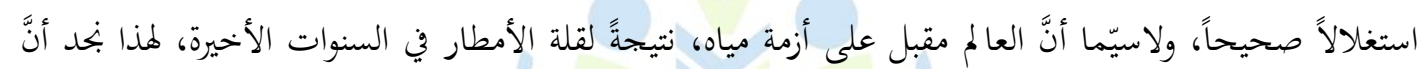

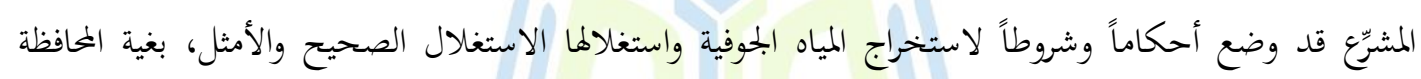

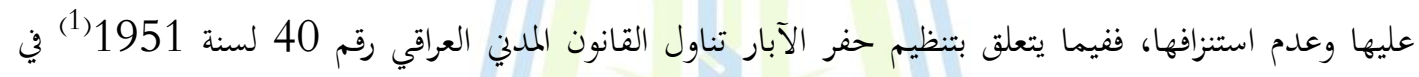

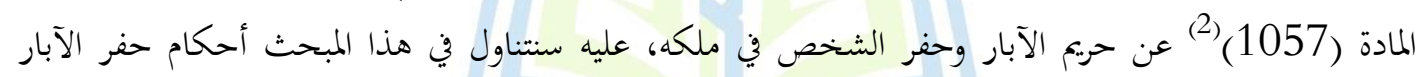

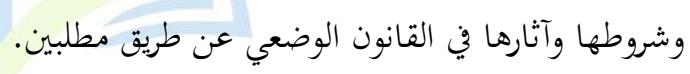

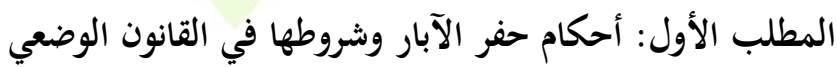

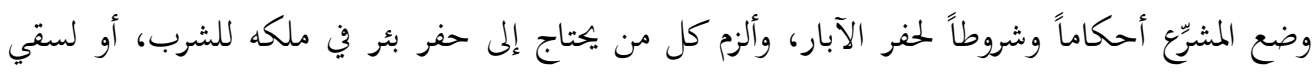

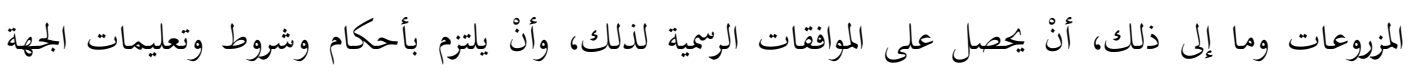

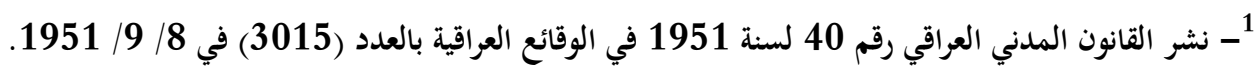

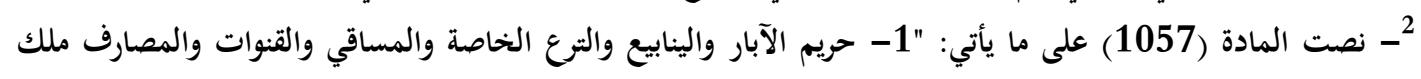

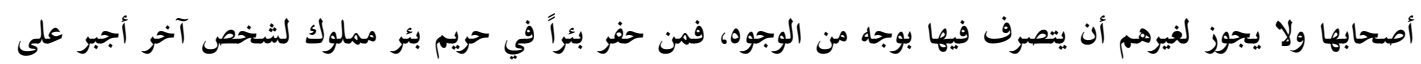

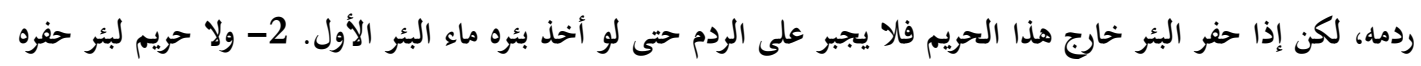

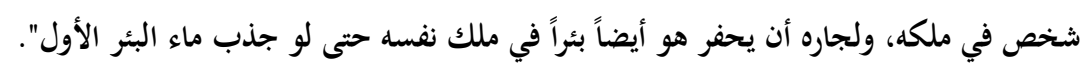


المختصة بمنح الإذن في حفر الآبار، كما وضع المشِّّع عقوبات على كل من يخالف هذه الأحكام والشروط

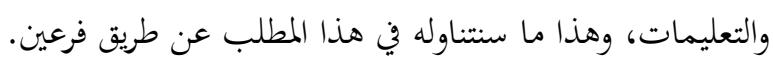
الفرع الأول: أحكام وشروط إدارية وتنظيمية لحفر الآبار

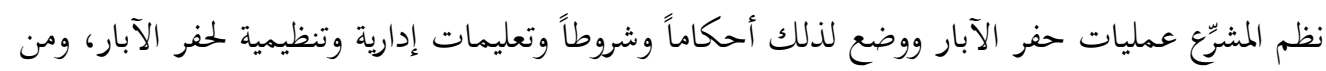

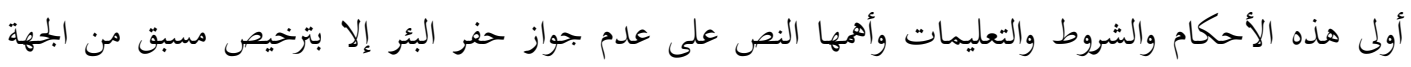

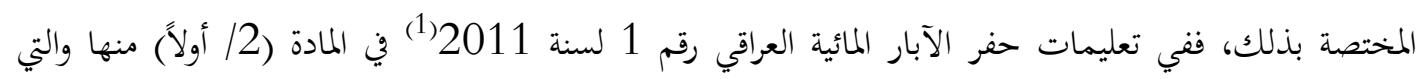

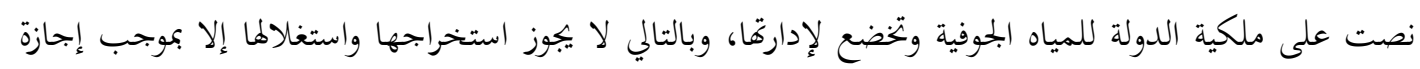

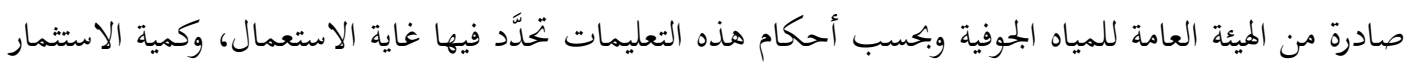

$$
\text { وأي شروط أخرى. }
$$

كما نصت المادة (2/ ثالثاً) من هذه التعليمات على عدم جواز حفر آبار ذات تدفق تلقائي إلا بموافقة

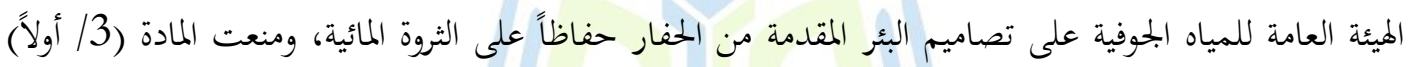

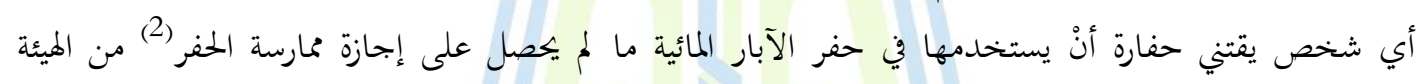
العامة للمياه الجوفية.

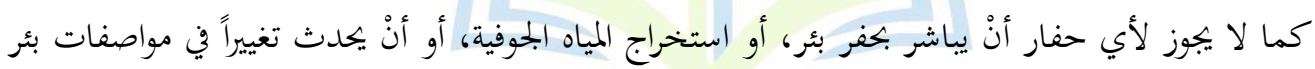

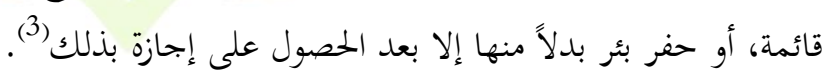

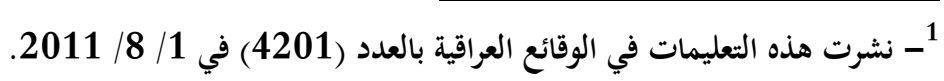

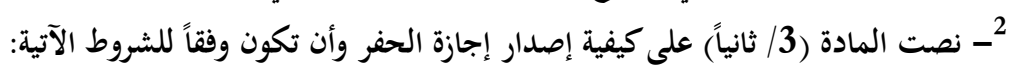

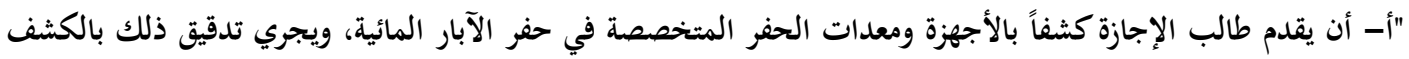

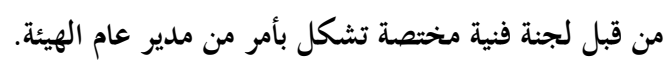

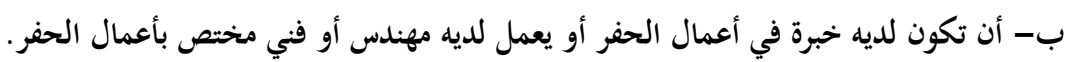

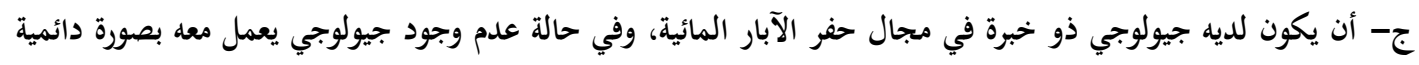

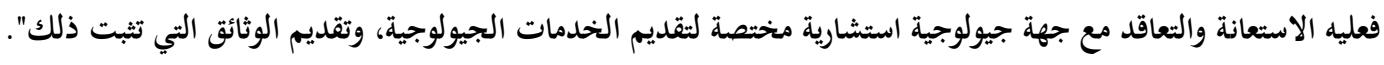
3- المادة (4/ أولاً) من تعليمات حفر الآبار رقم 1 لسنة 2011. 
وكذلك نص نظام مراقبة المياه الجوفية الأردني لسنة 2002 المعدل على أنَّ المياه الجوفية هي ملك للدولة

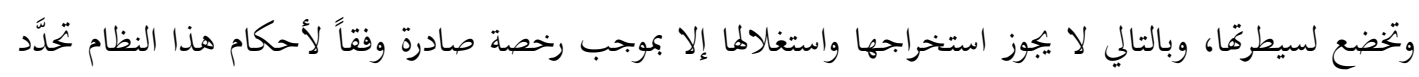

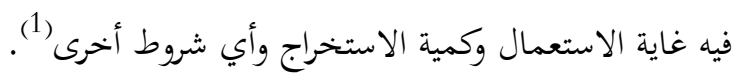

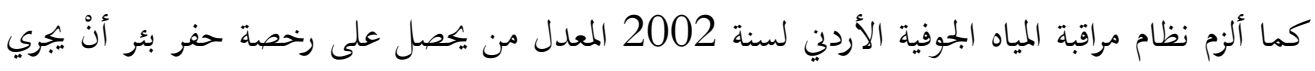

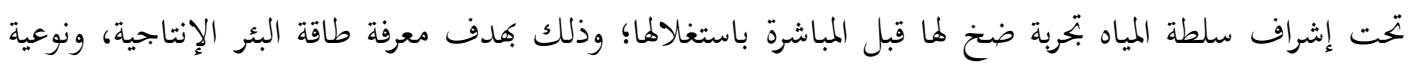

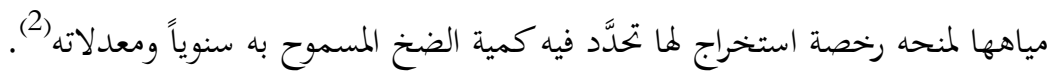

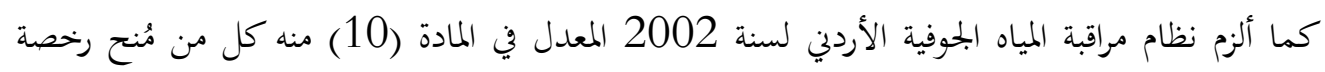

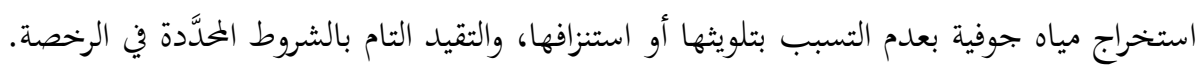

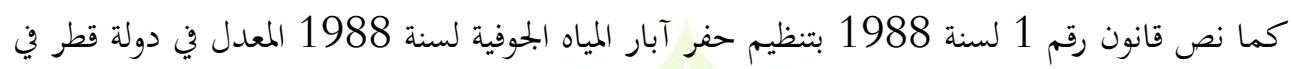

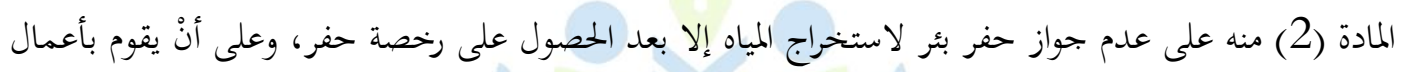
الحفر مقاول مرخص له بذلك. كذلك نص القانون رقم 6 لسنة 2006 بشأن تنظيم حفر آبار المياه الجوفية في إمارة أبو ظبي بدولة

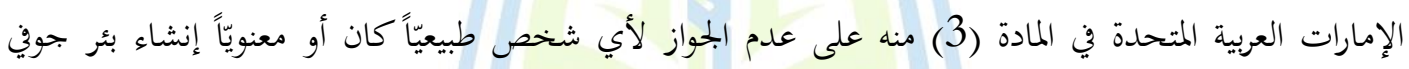

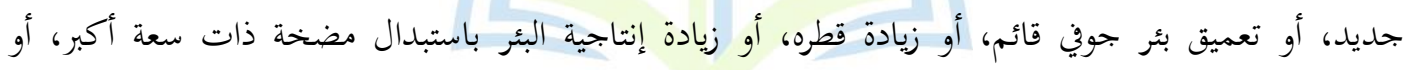

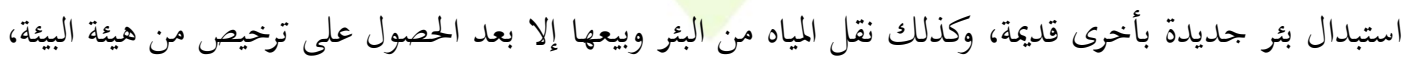

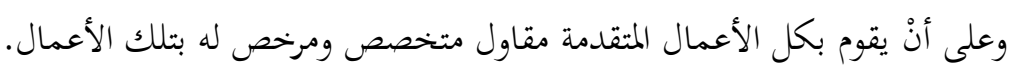

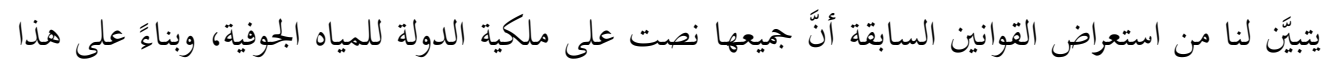

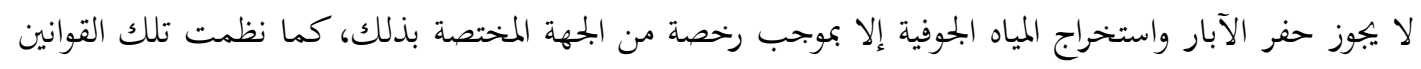

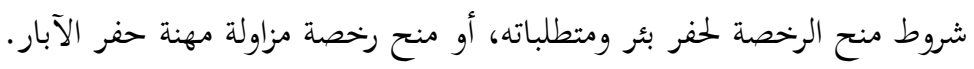

1 1 - المادة (3/ أ) من نظام مراقبة المياه الجوفية لسنة 2002 المعدل في الأردن.

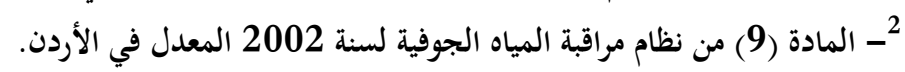


أما فيما يتعلق بالأمور الفنية المتعلقة بحفر الآبار فقد ألزمت تلك القوانين حافر البئر أو مقاول الحفر بجملة

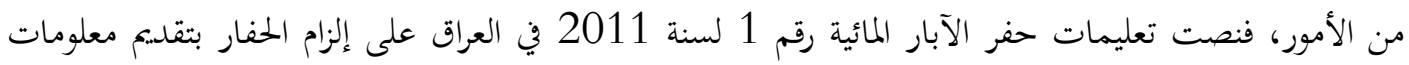

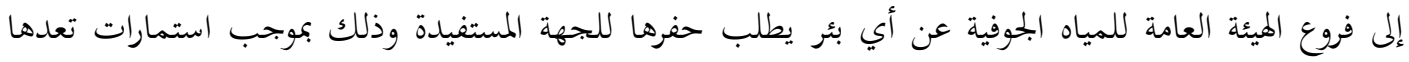

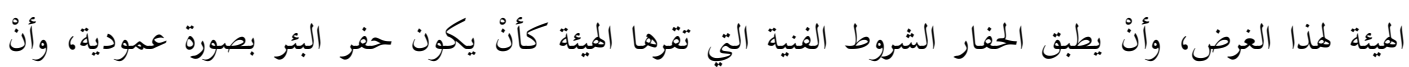

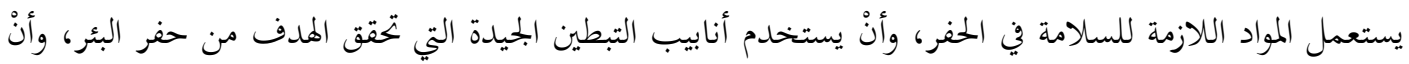
يلتزم الحفار بتقديم المعلومات الجيولوجية والهايدروجيولوجية والتحاليل الكيمياوية للمياه إلى الهيئة العامة للمياه

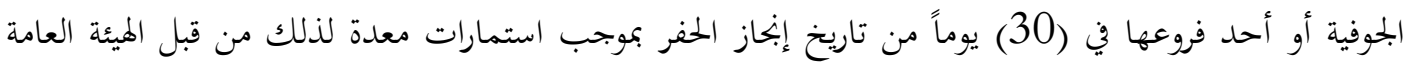

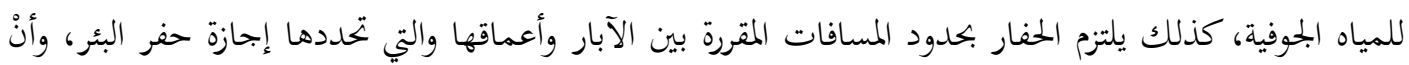

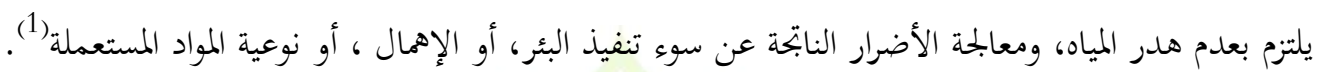

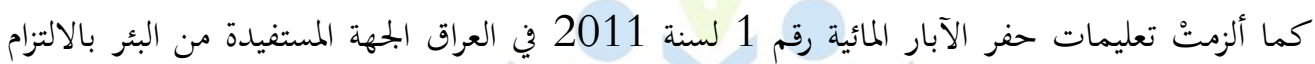

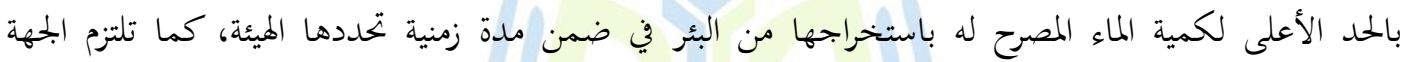

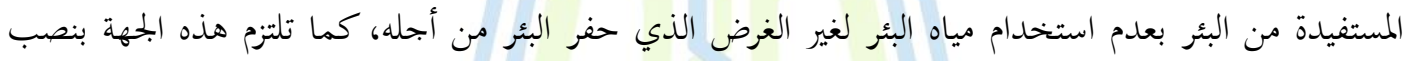

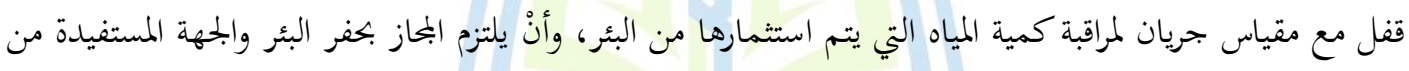

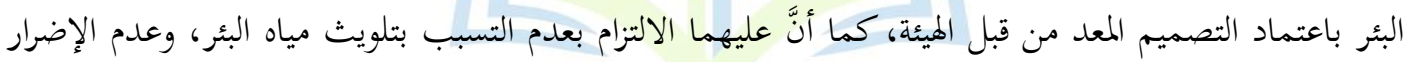
بالبيئة(2).

كذلك نص قانون رقم 1 سنة 1988 بتنظيم حفر آبار المياه الجويف المعدل في دولة قطر على التزام مقاول

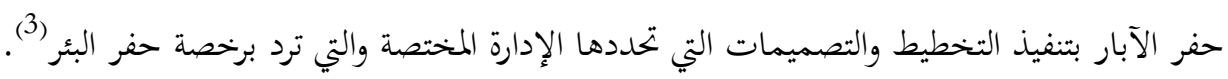

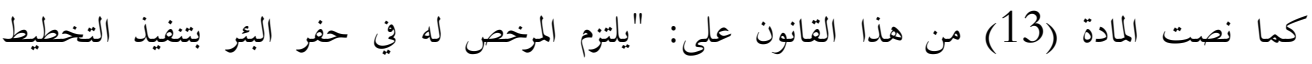

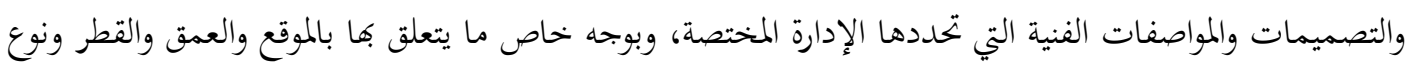

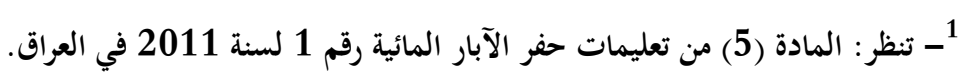

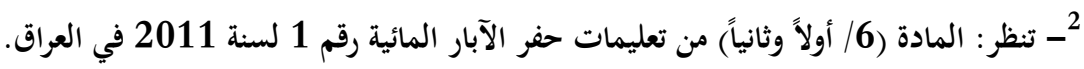
3- تنظر: المادة (6) من قانون رقم 1 لسنة 1988 بتنظيم حفر آبار المياه الجوفي المعدل في دولة قطر. 
المضخة وقوقا، كما يلتزم بتركيب عدادات مياه، بالمواصفات التي تحددها الإدارة المذكورة لقياس مقدار المنصرف من

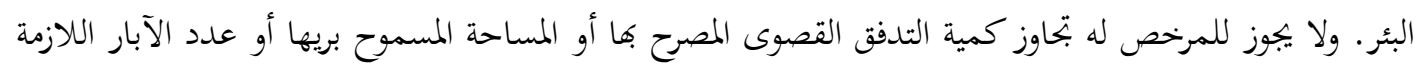

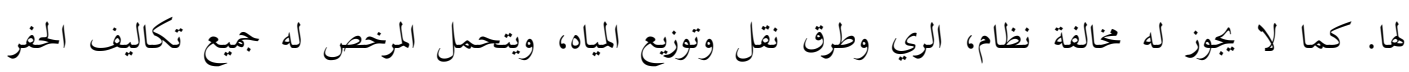

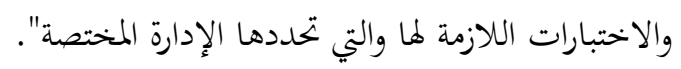

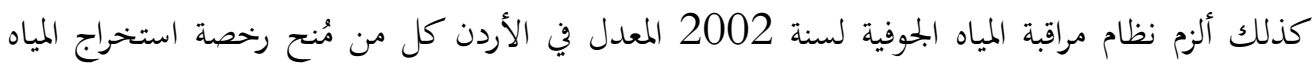

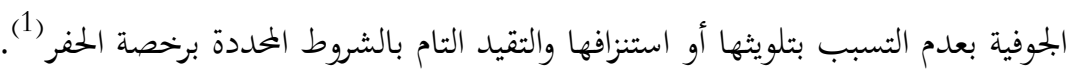

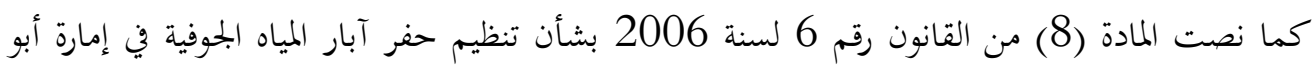

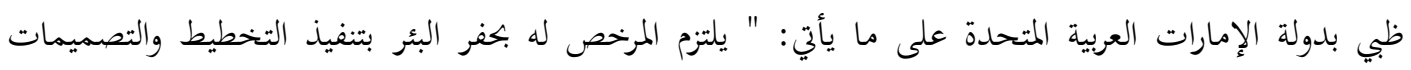

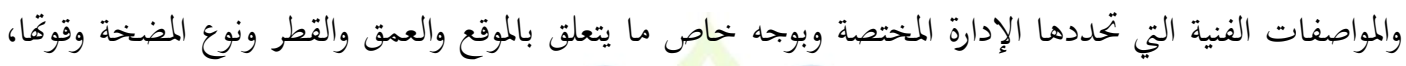

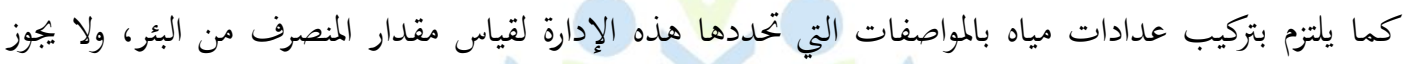

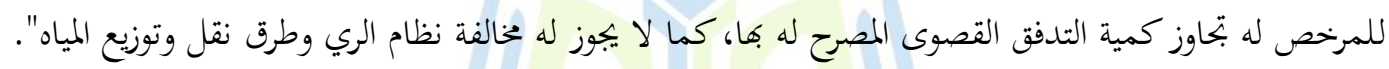

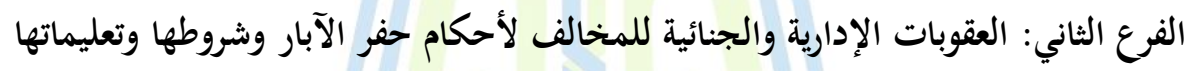

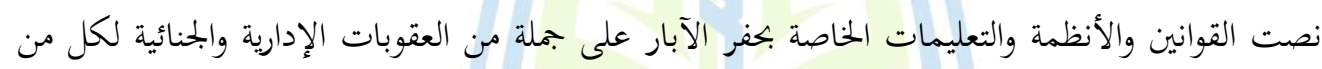

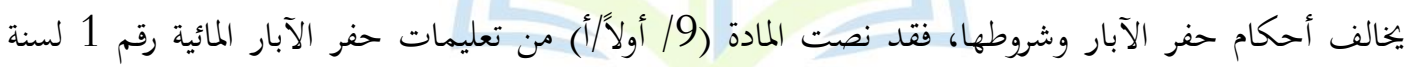

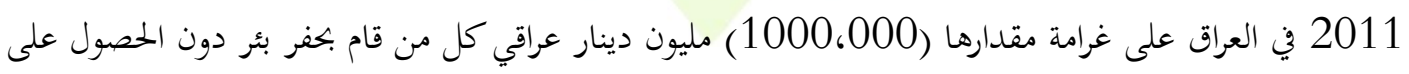

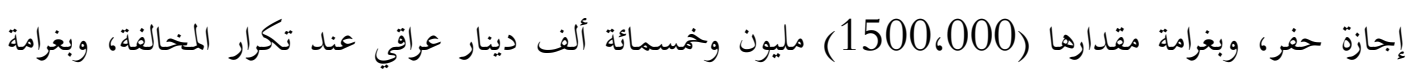
مقدارها (2000،000) مليونا دينار عراقي عند تكرار المخالفة للمرة الثالثة.

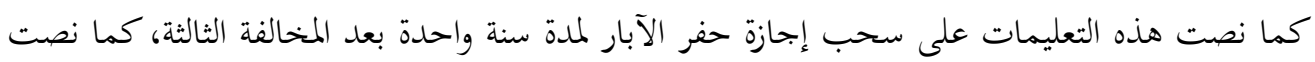
على سحب الإجازة هائياً في حال تكرار المخالفة بعد إعادة الإجازة المسحوبة (2).

1 - تنظر: المادة (10) من نظام مراقبة المياه الجوفية لسنة 2002 الدعدل في الأردن.

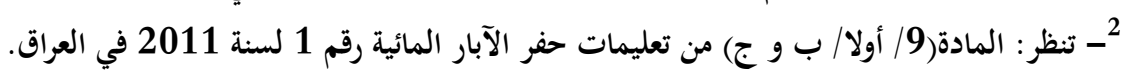


في حين نصت المادة (9/ ثانياً) من تعليمات حفر الآبار المائية رقم 1 لسنة 2011 في العراق على معاقبة

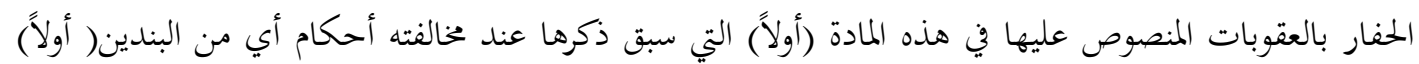
و(ثانياً)

$$
\text { من المادة (4)(1) و (ثالثاً) من المادة (5) (2) من هذه التعليمات. }
$$

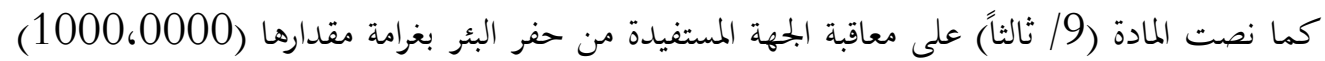

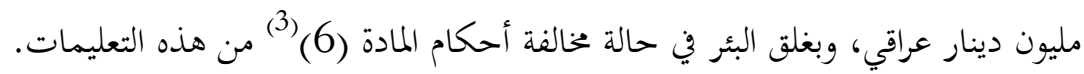

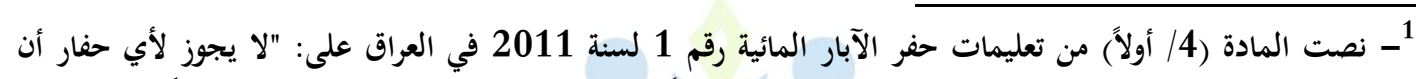

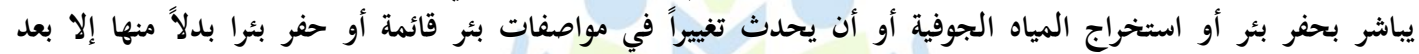

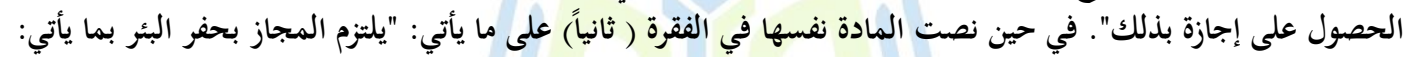

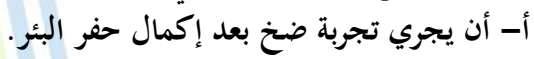

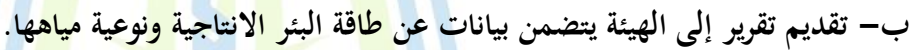

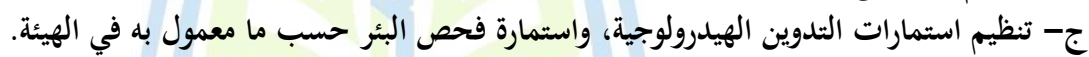

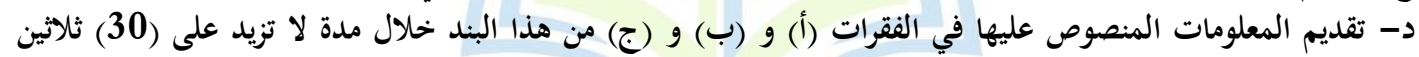

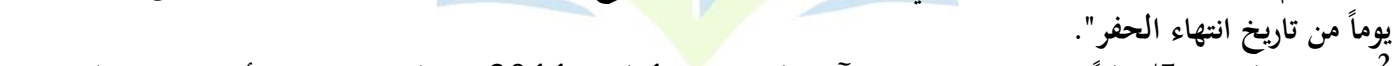

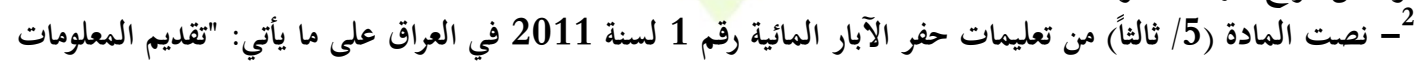

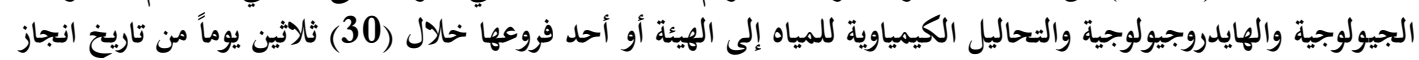
حفر البئر بموجب الاستمارات المعدة من الهيئة".

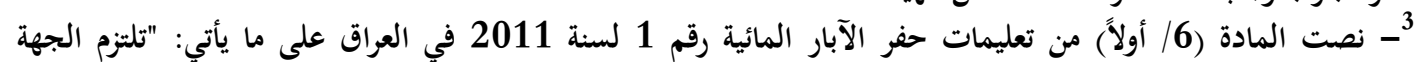

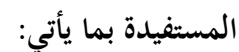
أ- الحد الأعلى لكمية المياه المصرح له باستخراجها من البئر ضمن مدة زمنية تحددها الهيئة.

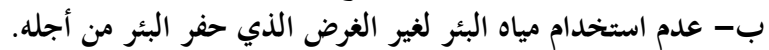

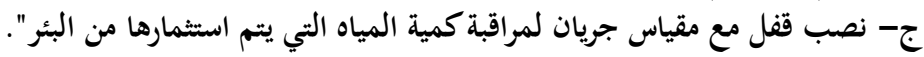

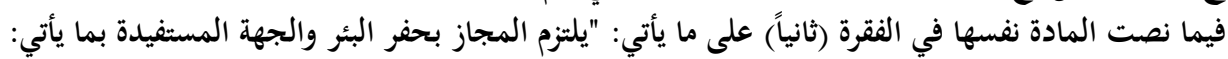
أ- أ- اعتماد التصميم المعد من الهيئة.

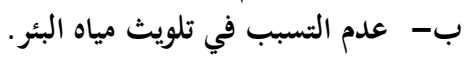
ج- عدم الإضرار بالبيئة". 
في حين نصت المادة (9/ رابعاً) من تعليمات حفر الآبار المائية رقم 1 لسنة 2011 في العراق على

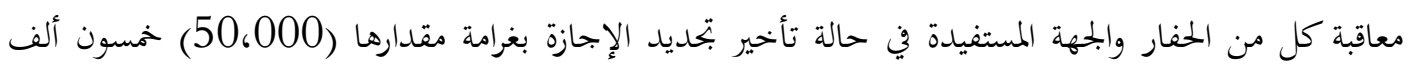
دينار عراقي عن كل شهر تأخير من تاريخ انتهاء نفاذ مدة الإجازة.

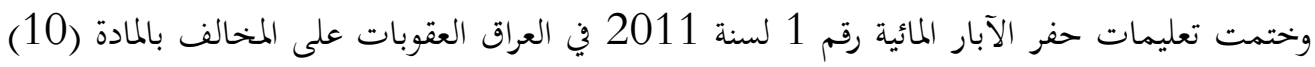

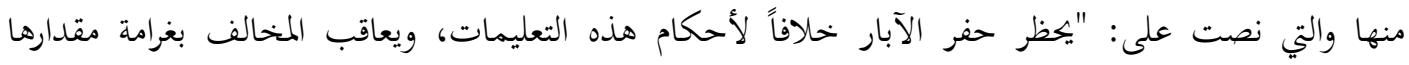

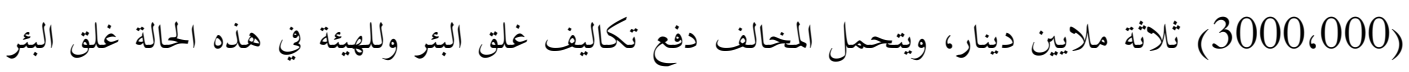
على نفقة الجهة المستفيدة".

أما فيما يتعلق بالعقوبات الإدارية والجنائية في قانون رقم 1 لسنة 1988 بتنظيم حفر آبار المياه الجوفية

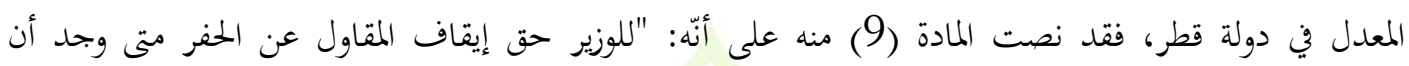

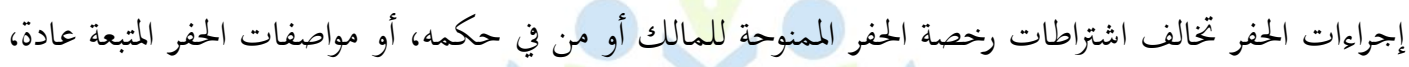

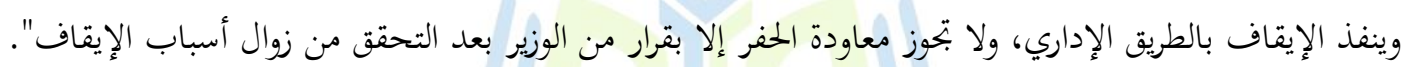

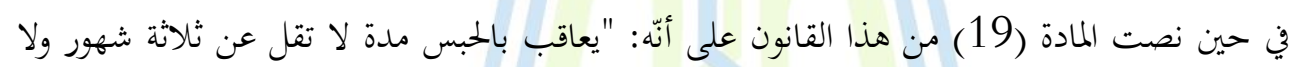

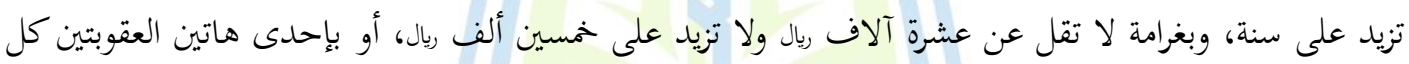

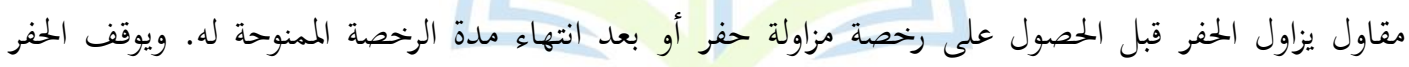

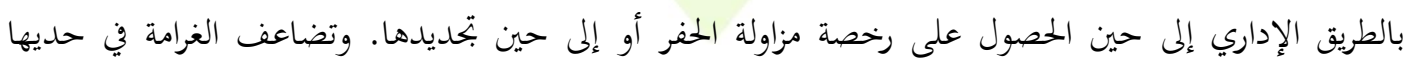

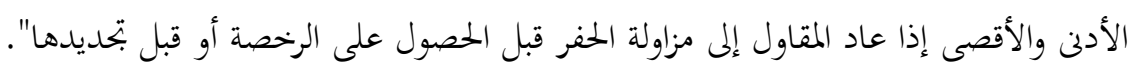

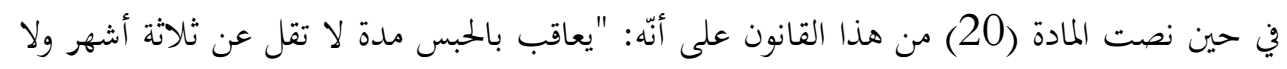

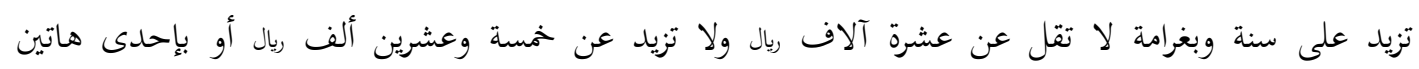

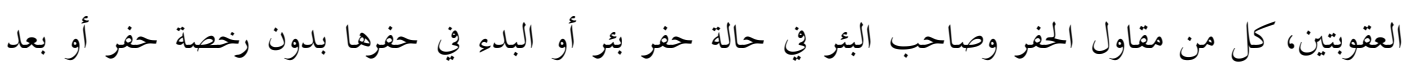

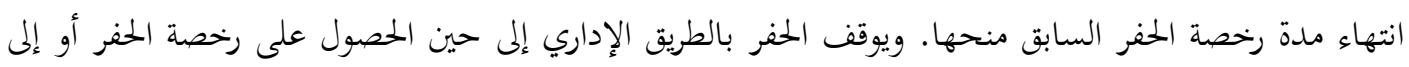

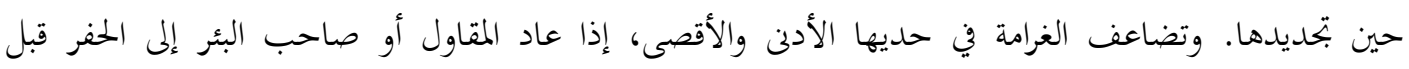


الحصول على رخصة الحفر وبحديدها. كما يجكم بوقف رخصة مزاولة الحفر الصادرة للمقاول لمدة لا تزيد على سنة".

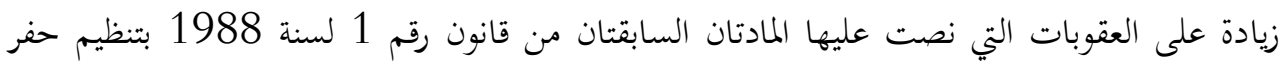

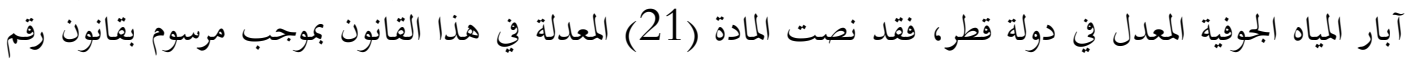

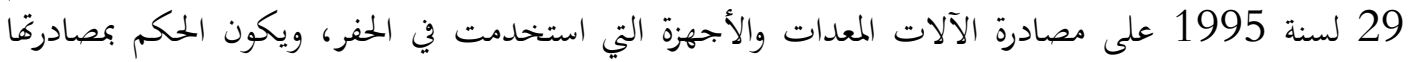

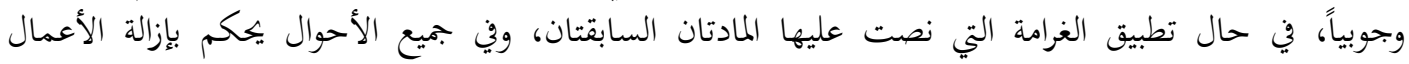

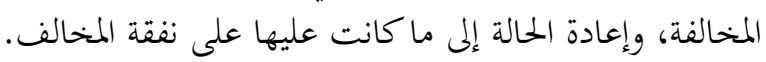

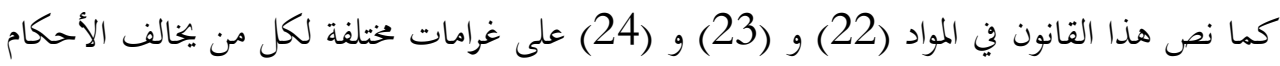
الواردة في هذا القانون.

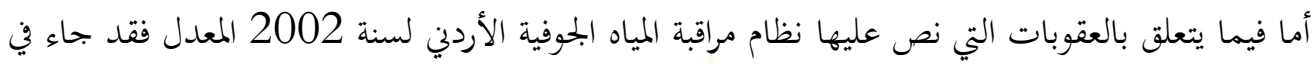

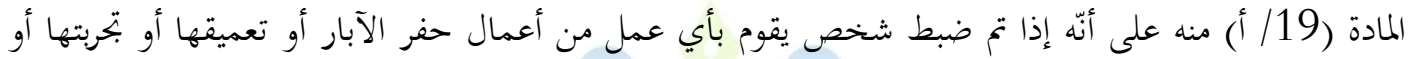

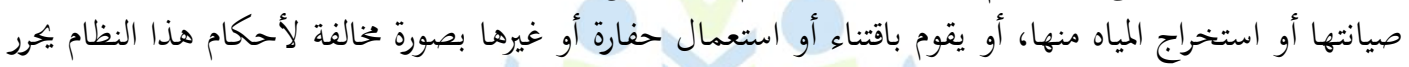

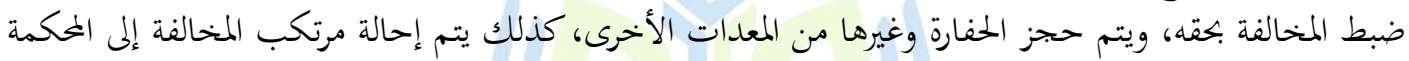
المختصة لمعاقبته بالعقوبات المنصوص عليها لماتيها في القانون.

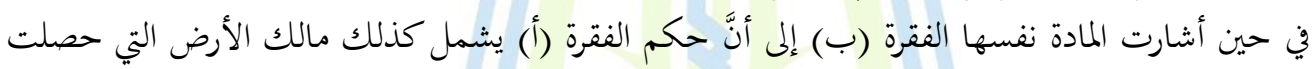

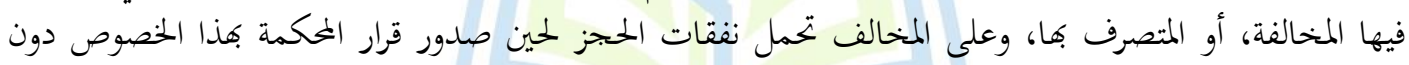

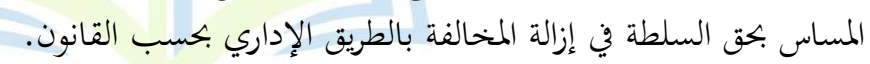

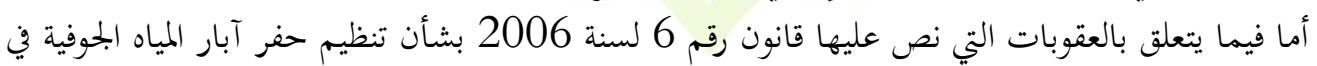

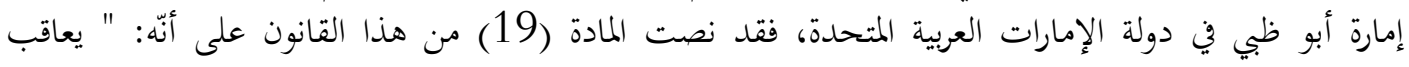

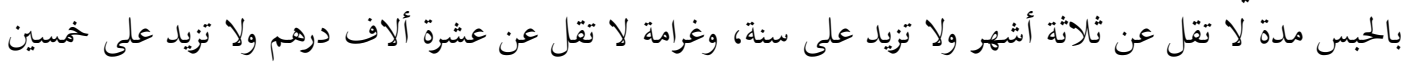

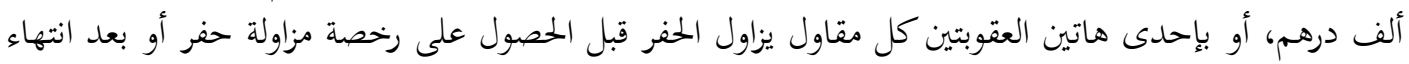

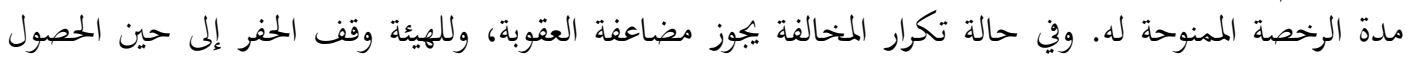
على رخصة مزاولة مهنة الحفر أو تجديدها". في حين نصت المادة (20) من هذا القانون على أنّه: "يعاقب بالحبس مدة لا تقل عن ثلالثة أشهر ولا تزيد

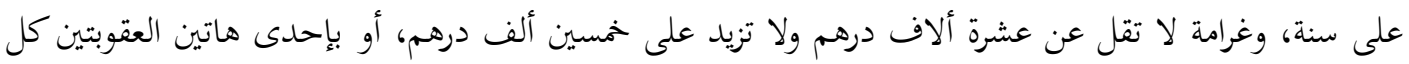

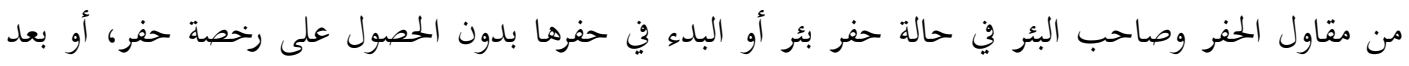

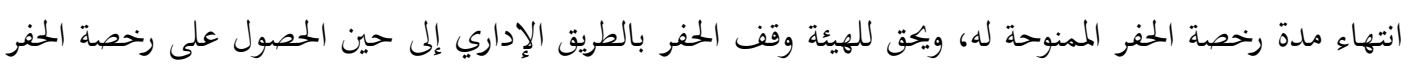


أو إلى حين بتديدها، وتضاعف الغرامة في حديها الأدنى والأقصى إذا عاد المقاول أو صاحب البئر إلى الحفر قبل

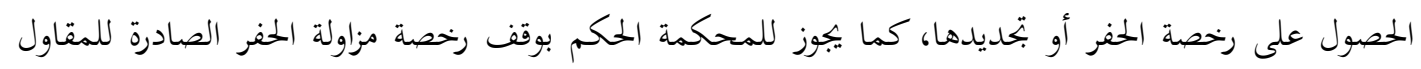
لمدة لا تزيد على سنة". زيادة على العقوبات التي نصت عليها المادتان (19) و(20) من هذا القانون أجازت المادة (21) من

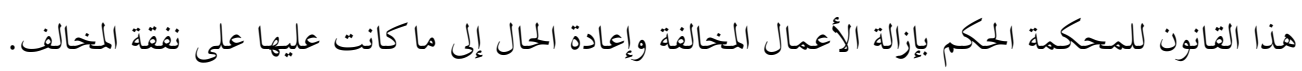
كذلك نص هذا القانون في المواد (22) و (23) و (24) على غرامات مختلفة لكل من يخالف الاحكام

$$
\text { الواردة في هذا القانون. }
$$

هذا باختصار العقوبات الإدارية والجنائية للمخالف لأحكام وتعليمات حفر الآبار والتي نصت عليها

$$
\text { القوانين والأنظمة والتعليمات في العراق وبعض الدول العربية. }
$$

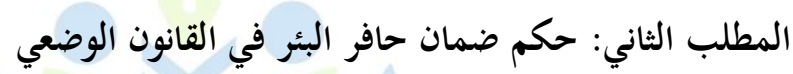

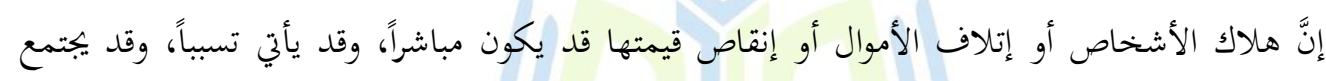
المباشر والمتسبب معاً. والمباشر: "هو الذي يكصل التلف من فعله دون أنْ يتخلل بينه وبين التلف فعل فاعل آخر"(1). أو "هو

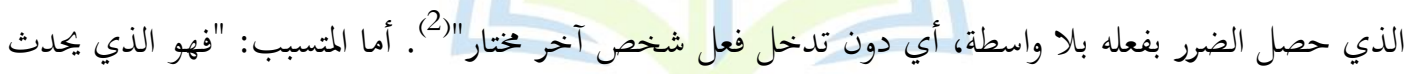

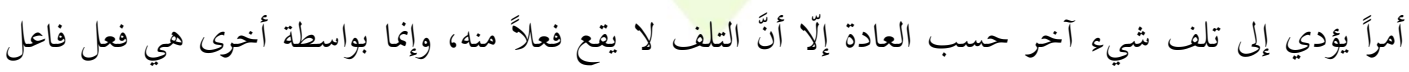
مختار" (3)

$$
\text { 1 }
$$

2- الزحيلي، أ. د. وهبة، نظرية الضمان أو أحكام المسؤولية المدنية والجنائية في الفقه الإسلامي دراسة مقارنة، دار الفكر،

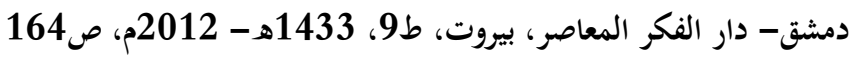

$$
\begin{aligned}
& \text { 3- المصدر نفسه، ص164- } 165 .
\end{aligned}
$$

96

Doi:10.37940/RJIS. 2021.2.1.3 
وبناءً على ما تقدم يكون هلاك الأشخاص وإتلاف الأموال مباشرة، عندما لا يتدخل أي أمر بين فعل

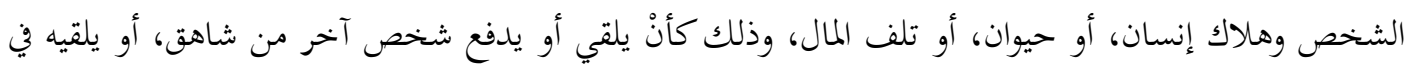

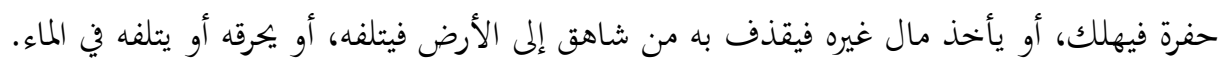

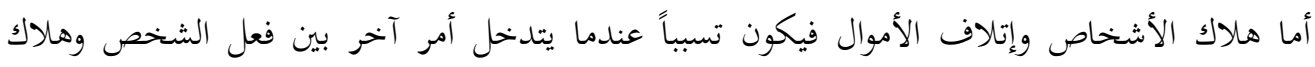

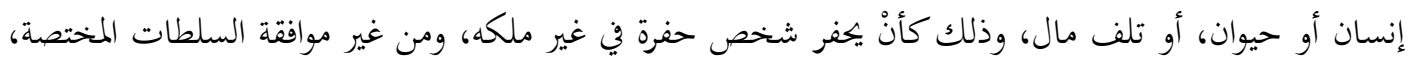

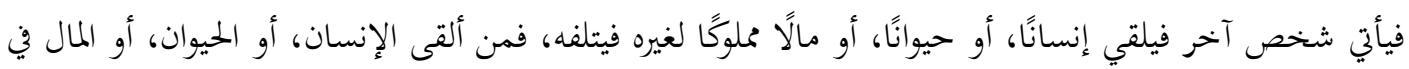
الحفرة يعدّ مباشراً، ومن حفرة الحفرة يعدّ متسبباً. وقد قررت الفقرة الأولى من المادة (186) من القانون المدني العراقي رقم (40) لسنة 1951 قيام مسؤولية

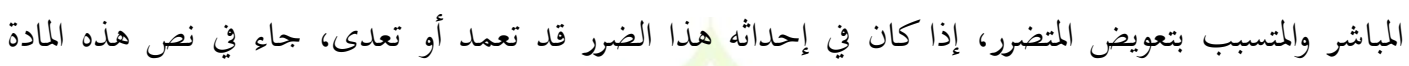

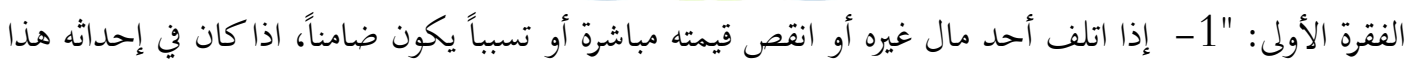

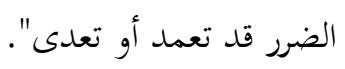
وكذا نصت المادة (257) من القانون المدني الأردني رقم 43 لسنة 1976 على: "1 "1 - أنْ يكون الإضرار

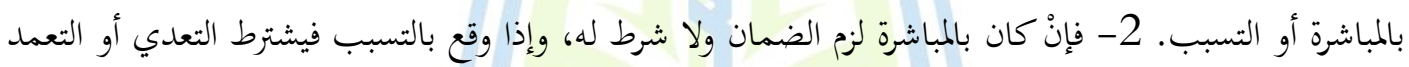

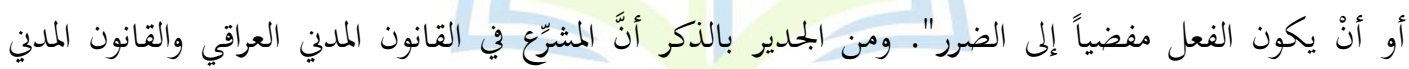
الأردني قد أخذا مفهومي التسبب والمباشرة من الفقه الإسلامي.

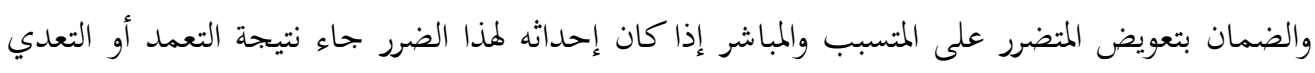

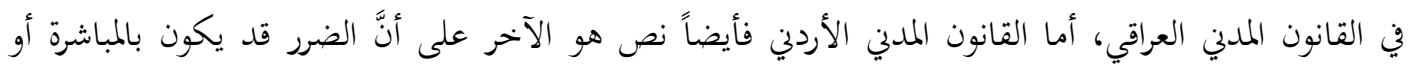

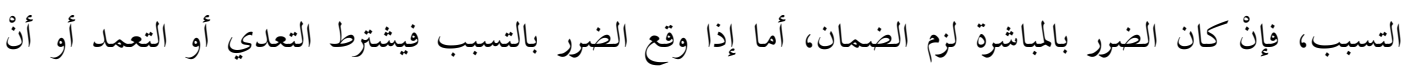

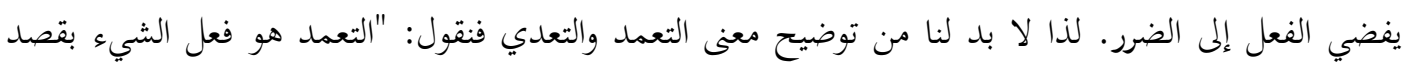

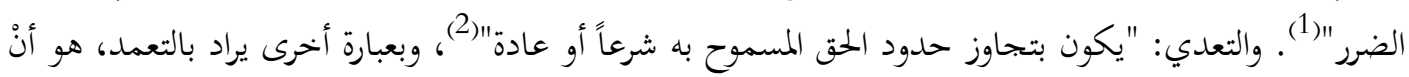

1 - الزحيلي، مصدر سابق، ص172. 2- المصدر نفسه، ص173. 


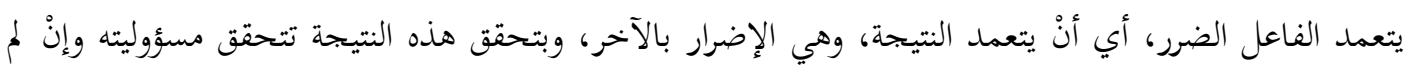

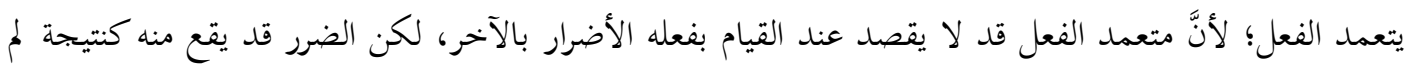

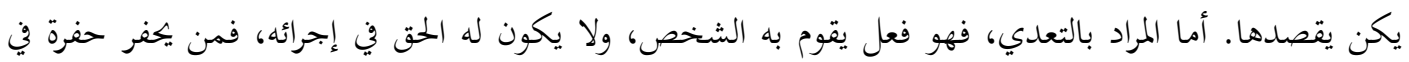

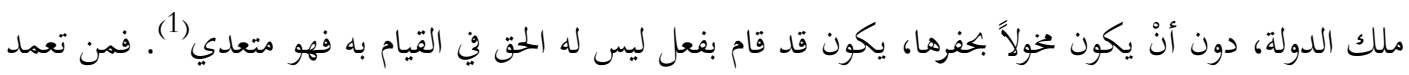

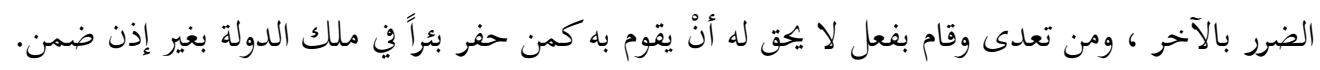

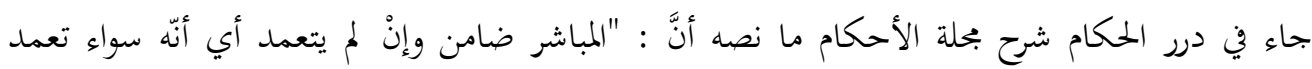

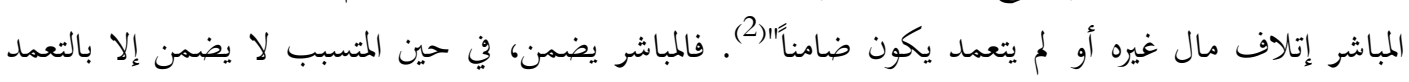
والتعدي. "والفرق بين المباشر المتسبب هو أنّه يشترط لضمان المتسبب أنْ يكون متعدياً والمباشر يضمن على حالين

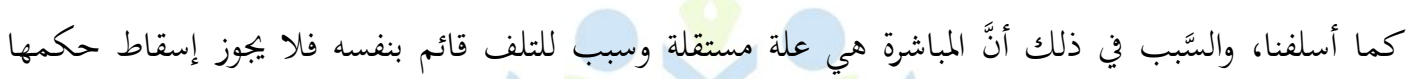

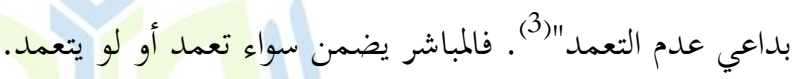

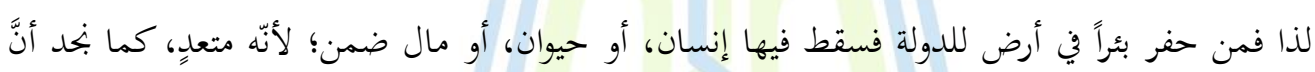

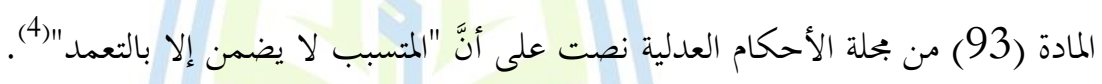

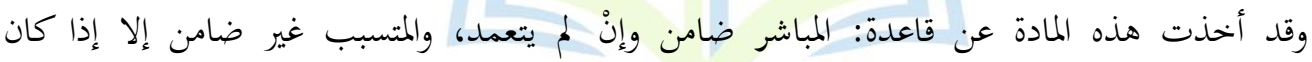

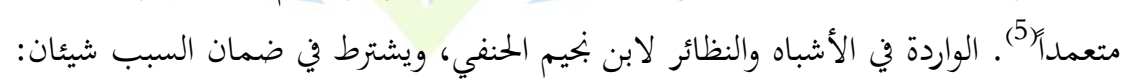

$$
\text { 2-1 }
$$

1 - ينظر: البياتي، القاضي موفق حميد، شرح المتون الموجز المبسّط في شرح القانون المدني (العراقي)، القسم الأول، مصادر

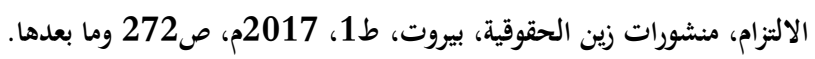

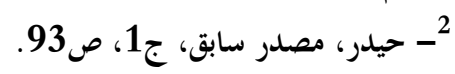

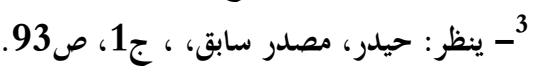

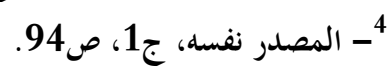
5 - ينظر: ابن نجيم، مصدر سابق، ص243. 


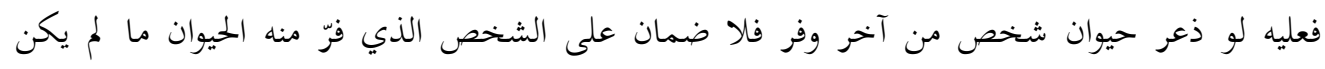

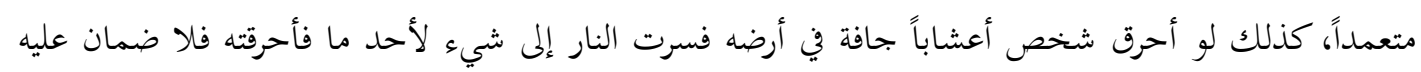

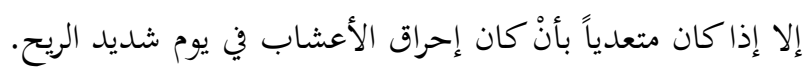

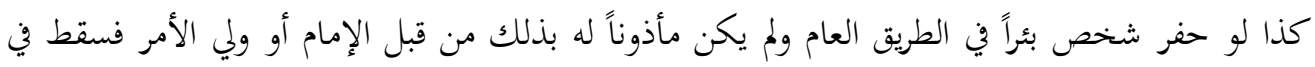

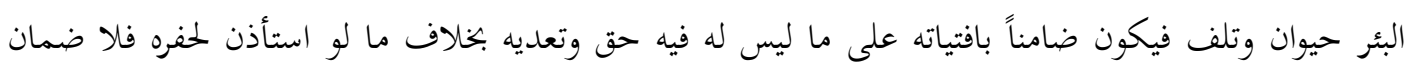
عليه.

أما لو حفر إنسان بئراً في ملكه فليس عليه ضمان؛ لأنَّ الإنسان له أنْ يتصرف في ملكه كيفما شاء فلا

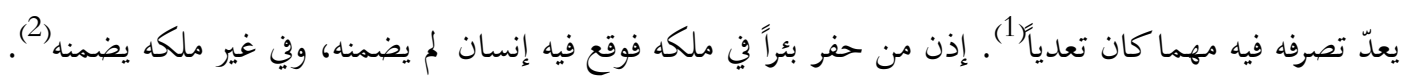

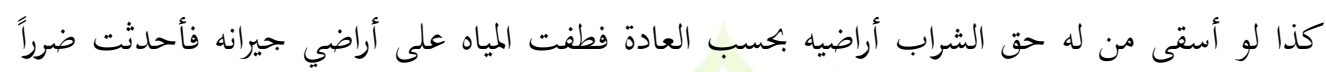
فيها فليس من ضمان عليه. أما لو كان الأسقاء على خلاف العاب آراضيه لعادة فيكون ضامناً.

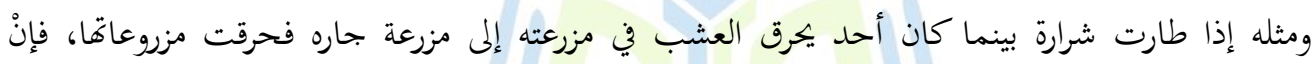

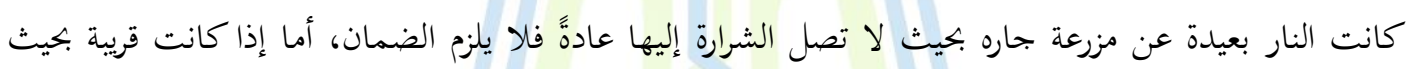

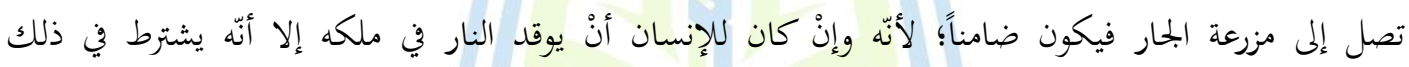
السلامة (3).

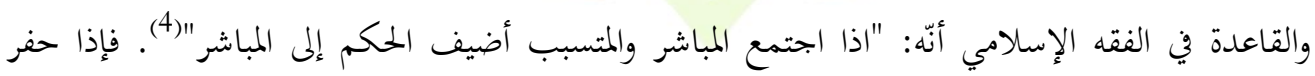

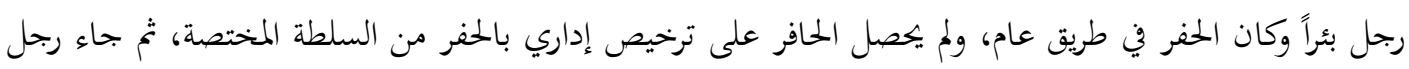

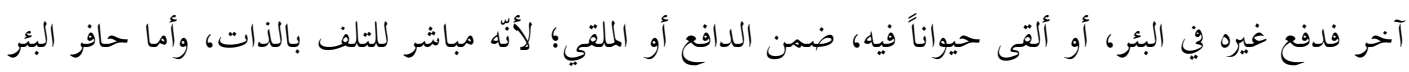

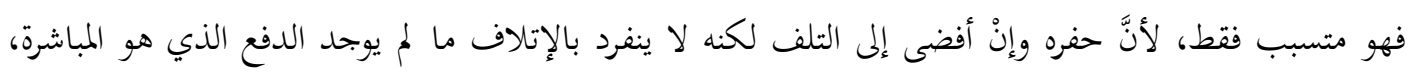

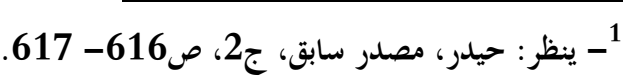

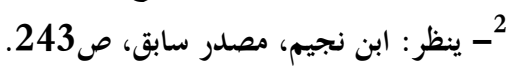

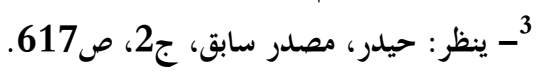

$$
\begin{aligned}
& \text { 4-- حيدر، مصدر سابق، ج1، صيدر، صناب، ج91. }
\end{aligned}
$$


وإذا كان السبب لا يعمل بانفراده فلا يضمن المتسبب مع المباشر؛ لأنَّ الحفر لا يعمل بانفراده شيئاً من دون

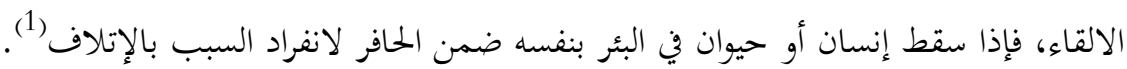

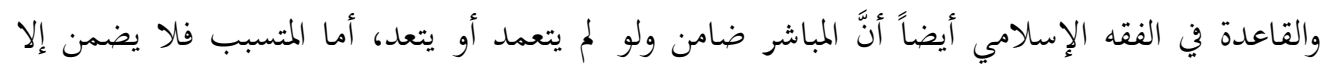

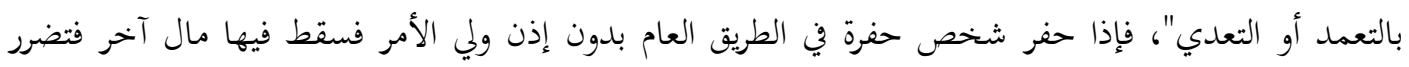

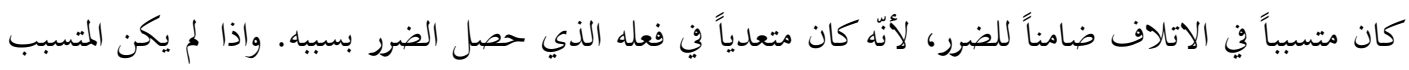

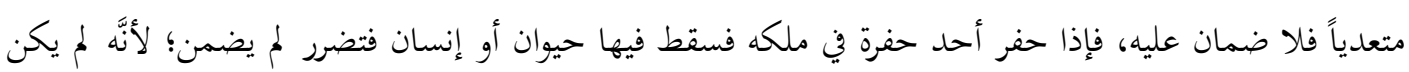

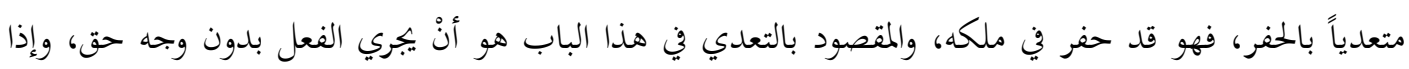

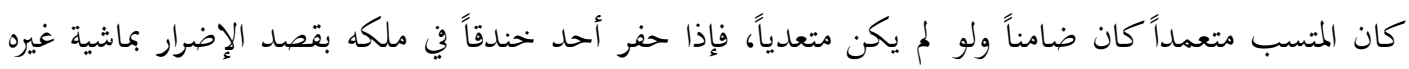

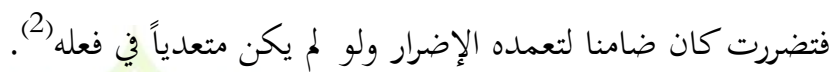

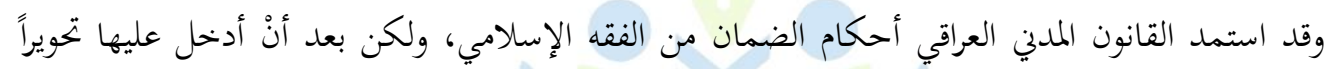

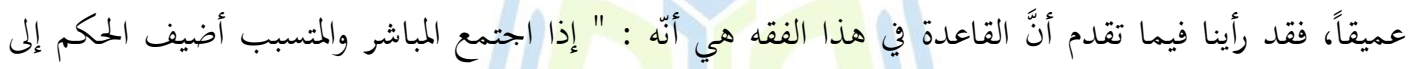

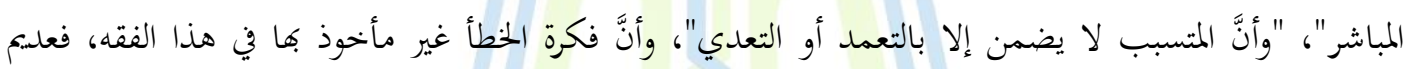

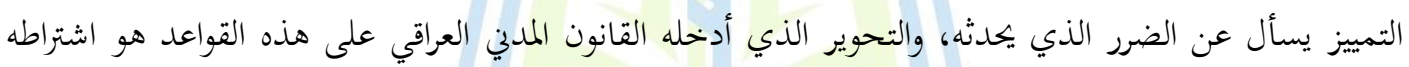

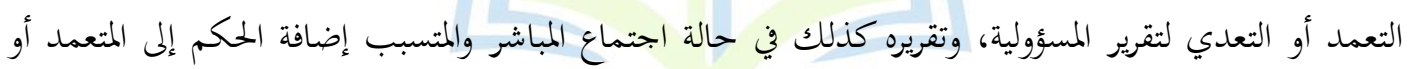

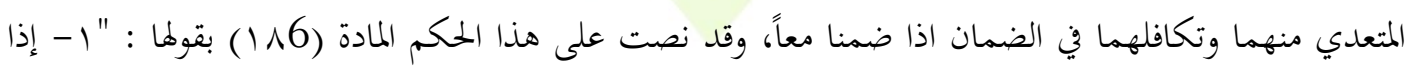

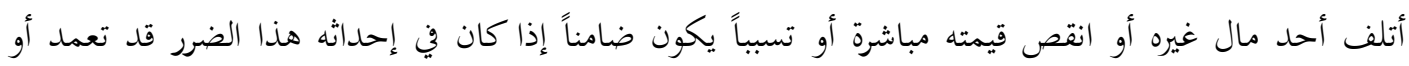

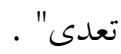

r - وإذا اجتمع المباشر والمتسبب ضمن المتعمد أو المتعدي منهما، فلو ضمناً معاً كانا متكافلين في

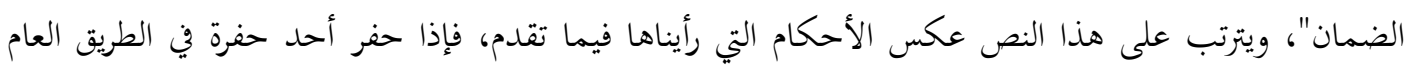

1 - ينظر: الزحيلي، مصدر سابق، ص165.

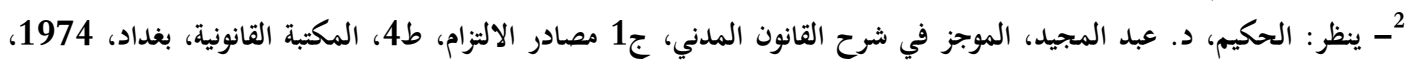
ص499 وما بعدها. 
بدون إذن السلطة المختصة وجاء آخر وألقى فيها مال غيره فاتلفه كان الضمان على الاثنين: الحافر والملقي؛ الحافر

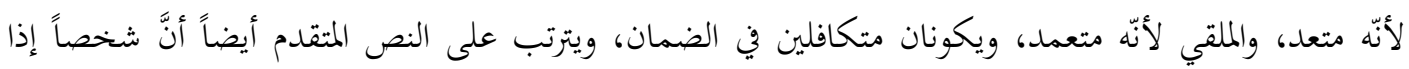

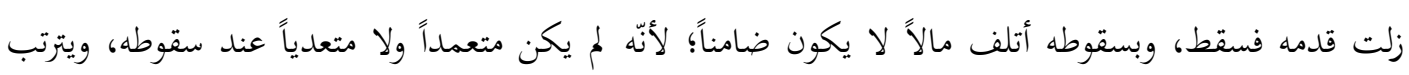

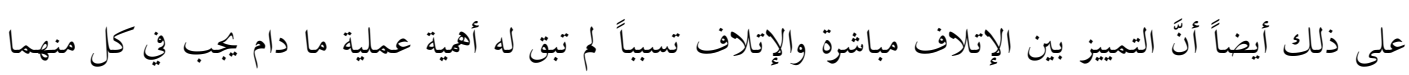

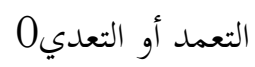

ونخن لا نيل إلى ما ذهب إليه القانون المدني العراقي من اشتراط التعمد أو التعدي لتقرير الضمان، ومنيل إلى

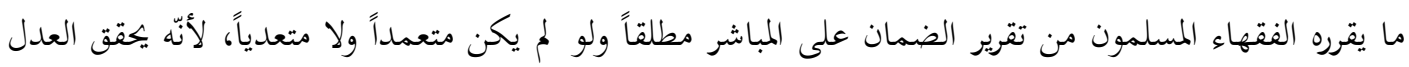

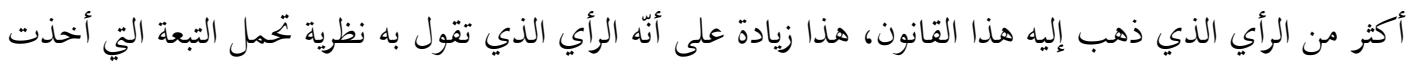

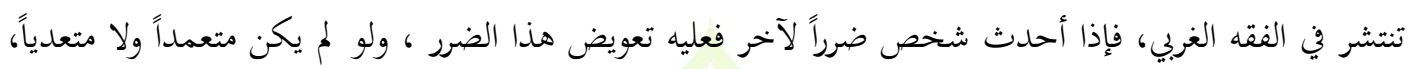

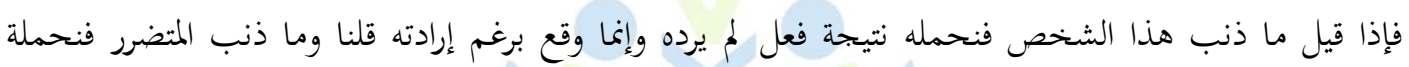

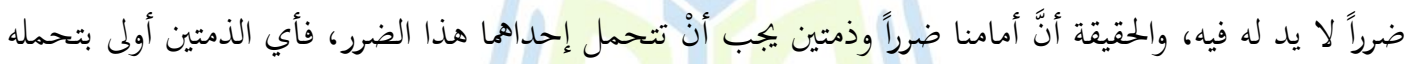

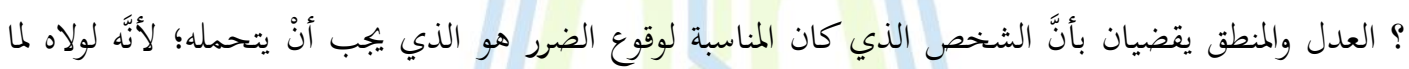

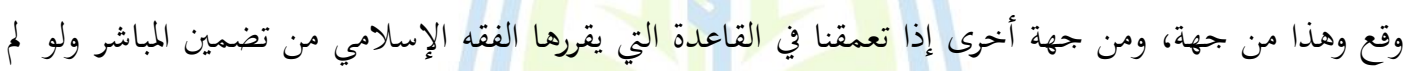

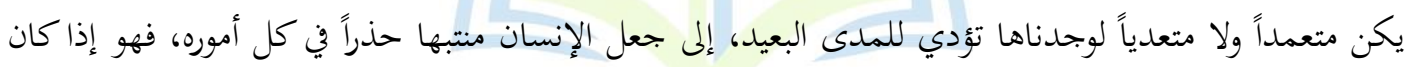

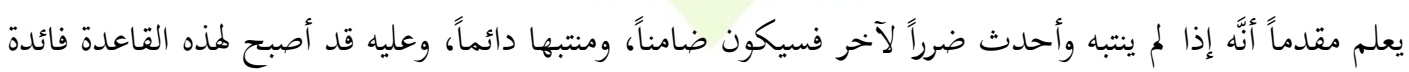
لالإنسان في حياته الخاصة(1).

بعد كل ما ذكرناه فيما يتعلق بموضوعات بحثنا هذا نستطيع أنْ نعقد مقارنة بسيطة في أحكام حفر الآبار

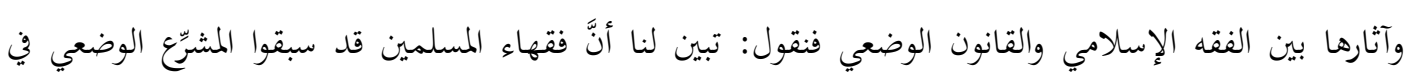

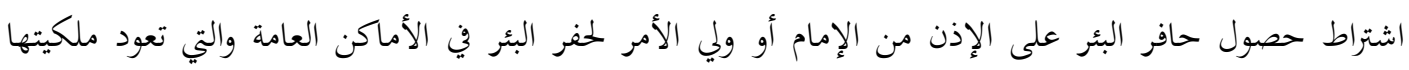

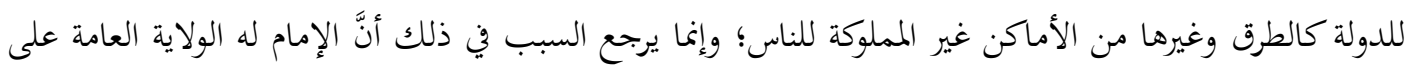

$$
1 \text { - ينظر: الحكيم، مصدر سابق، ص449 - } 500 .
$$


المسلمين، فهو الذي له حق تدبير شؤوفم وأمورهم، فحفر الآبار في هذه الأماكن العامة بغير إذن الإمام يُعد تعدياً

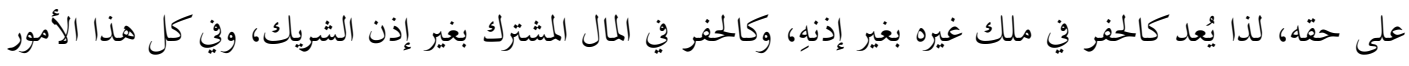

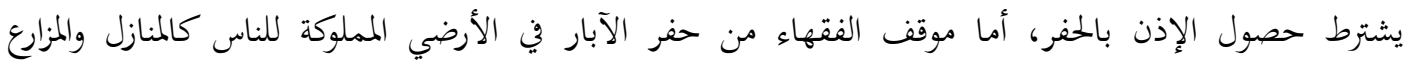

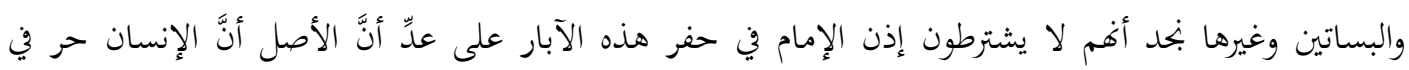

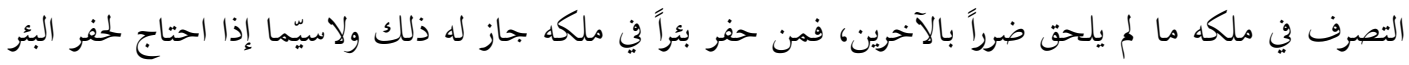

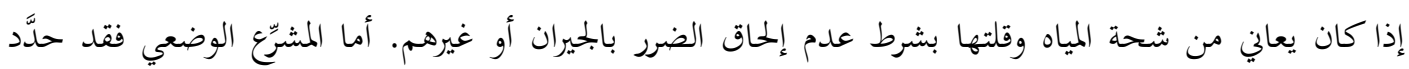

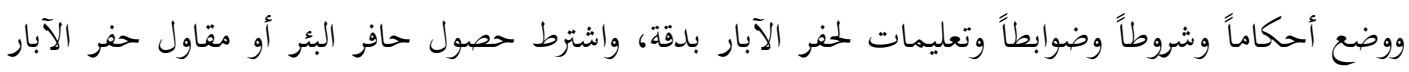

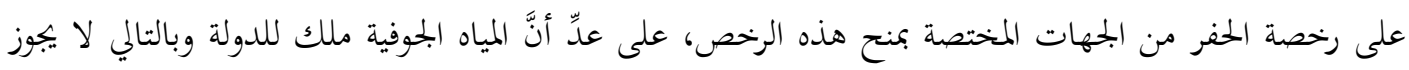

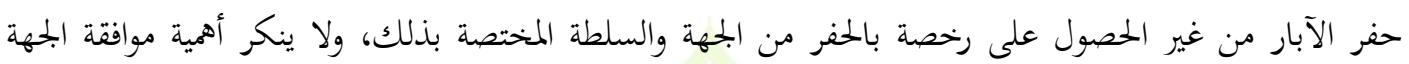

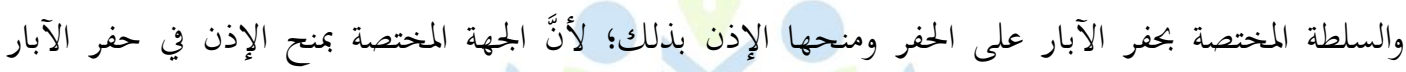

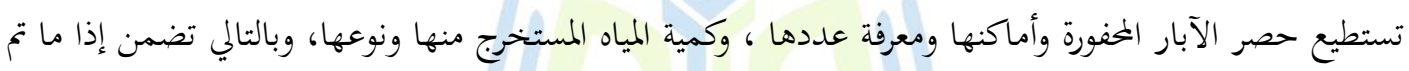

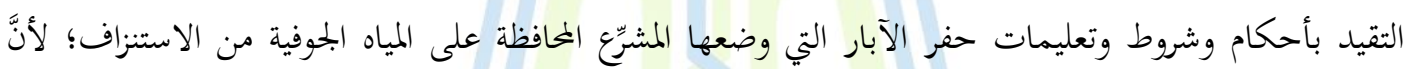

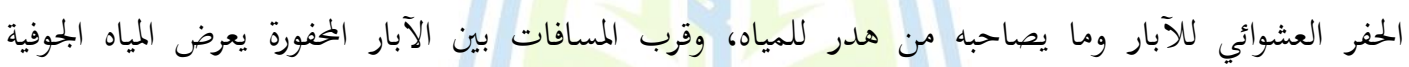

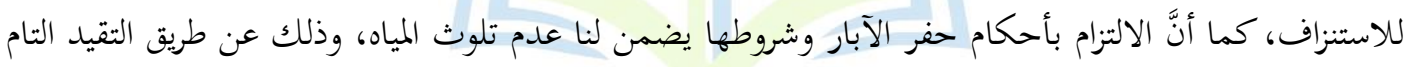
بأحكام الحفر وشروطه من حيث والمعدات الآلات المستخدمة في الحفر، وإجراء عمليات التبطين للآبار، والالتزام

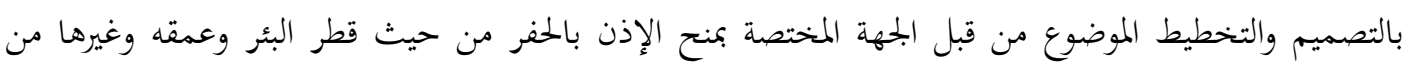

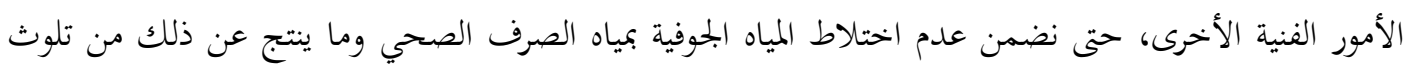

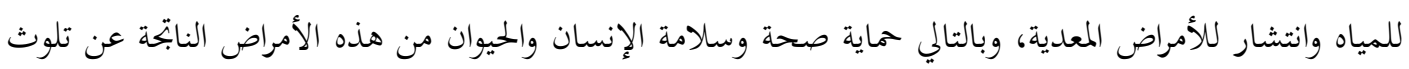
المياه.

ولا يعاب على فقهاء المسلمين عدم وضعهم أحكامًا وشروطاً وتعليمات لحفر الآبار بهذه الدقة التي وضعها

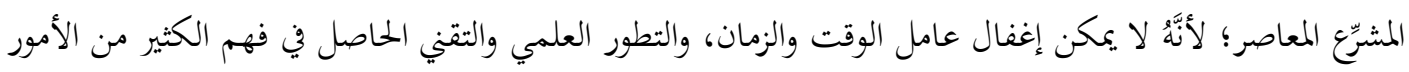

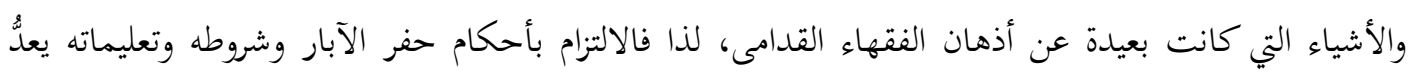


واجباً شرعياً وقانونياً ينبغي لكل من يقدم على حفر الآبار أنْ يلتزم بها حفاظاً على المياه الجوفية من الاستنزاف،

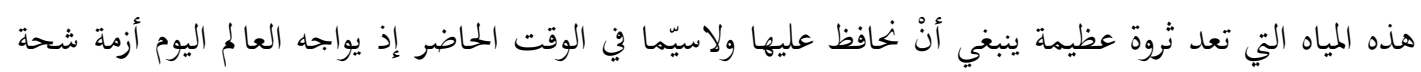
المياه وقلتها، وحفاظاً على مياه هذه الآبار من التلوث.

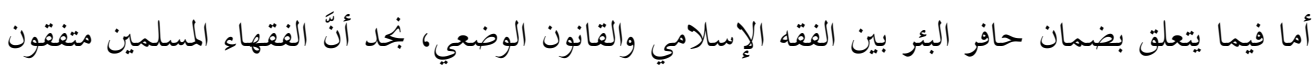

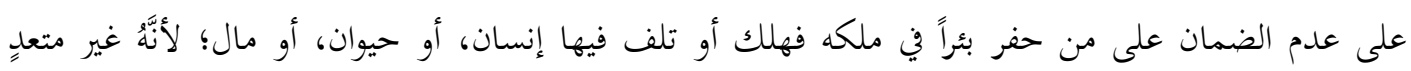

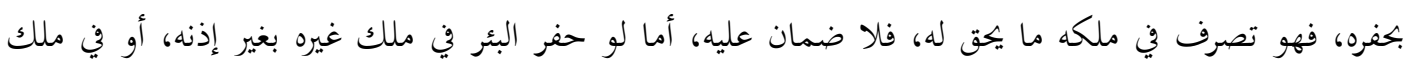

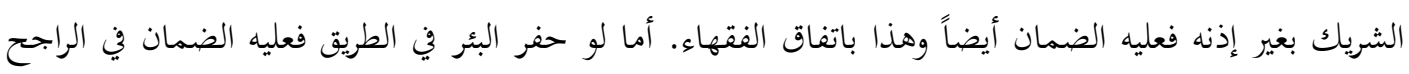

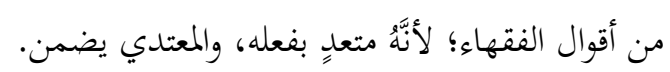

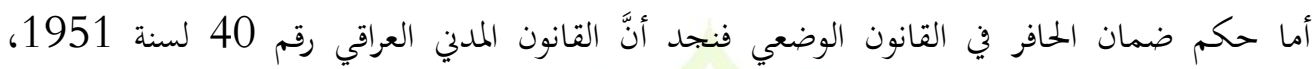

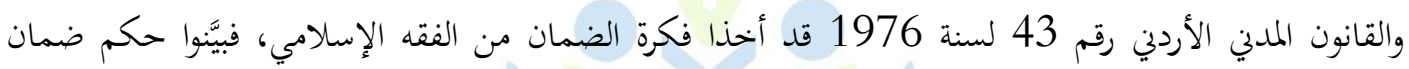

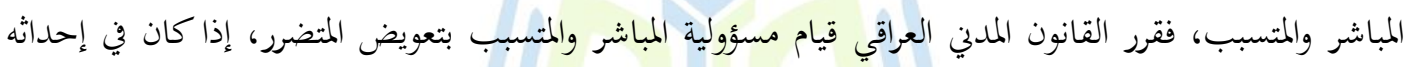

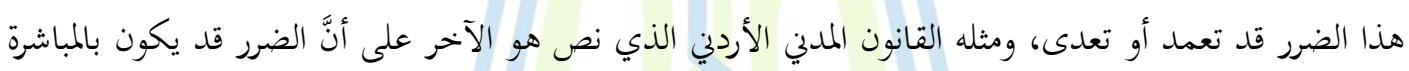

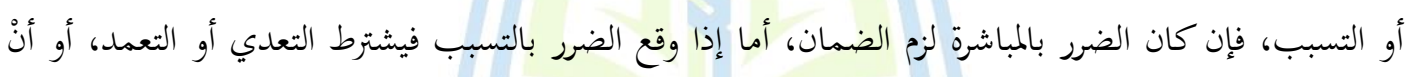

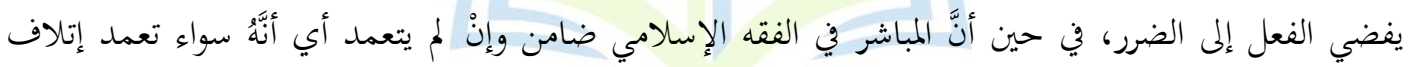

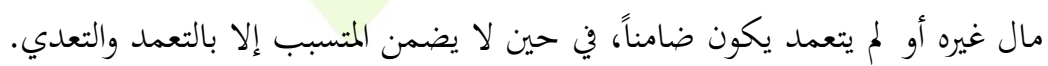

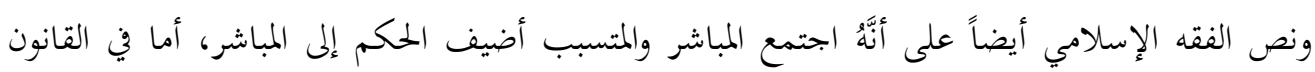

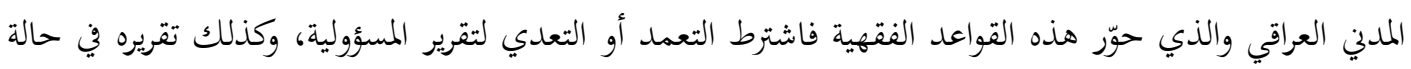

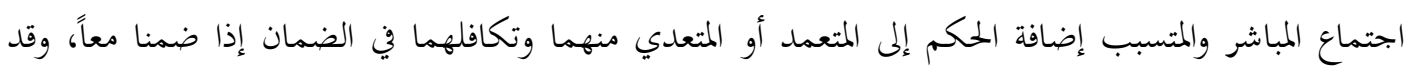

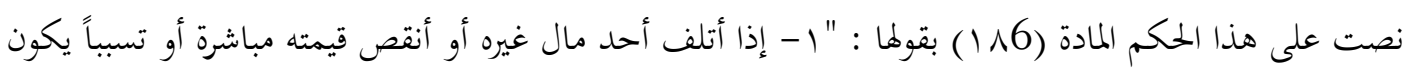

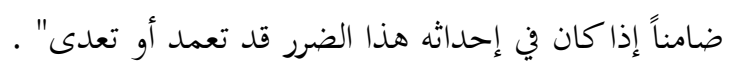

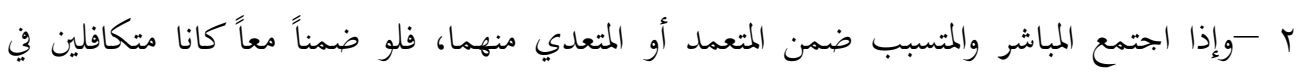

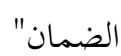


لذا لا نميل إلى ما ذهب إليه القانون المدني العراقي من اشتراط التعمد أو التعدي لتقرير الضمان، وإنما نميل

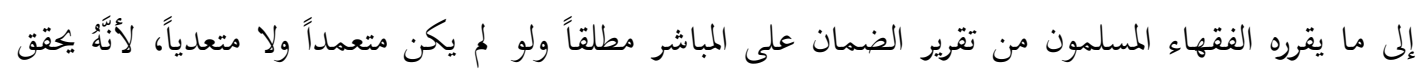
العدل أكثر من الرأي الذي ذهب إليه هذا القانون.

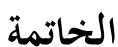

بعد هذا العرض للعنوانات البارزة لمذا البحث والوقوف في محطاته الرئيسة، وتحديد إطاره العام لا بد من

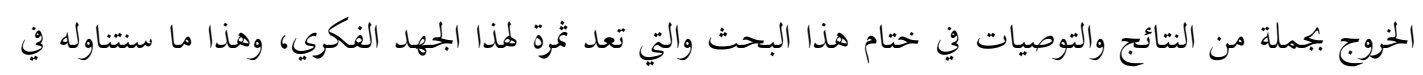

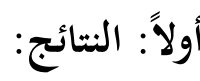

1- - البئر: هو حفرة أو خندق أو ثقب يتم إحداثه في الأرض بآلة أو جهاز للوصول إلى المياه

$$
\text { الجوفية واستخراجه. }
$$

2- اختلف الفقهاء في حكم حفر الناس للآبار في الطرق الواسعة إذا كان ذلك بغير إذن الإمام

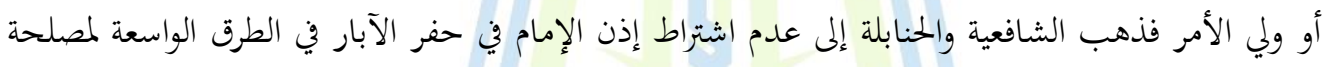

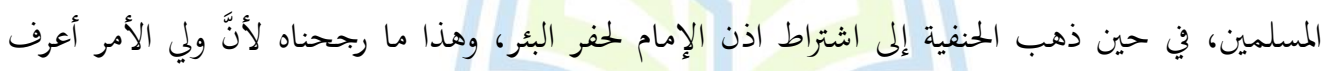
بالمصلحة من غيره.

3- ذهب فقهاء المالكية والشافعية والحنابلة إلى عدم جواز حفر البئر في الطريق الضيق؛ لما في

$$
\text { ذلك من ضرر واضح على المسافر . }
$$

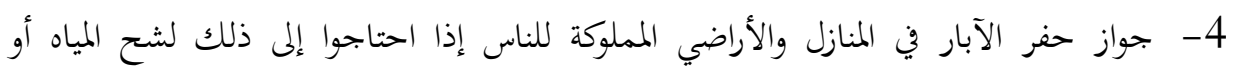

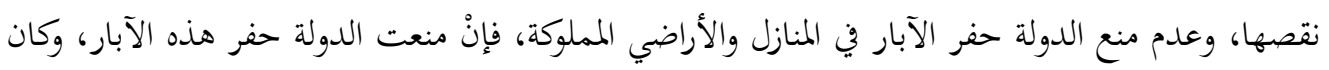

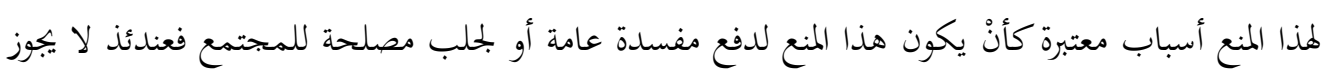
حفر هذه الآبار.

5- ذهب فقهاء الحنفية والمالكية والحنابلة إلى تحريم حفر البئر في المسجد، وعلَّلوا ذلك بعلل منها، أنَّ البقعة مستحقة للصلاة، فتعطيلها عدوان. 
6- عدم جواز حفر الآبار من أموال الزكاة؛ لأنَّ الأصل في الزكاة تمليكها للمستحقين، والتملك

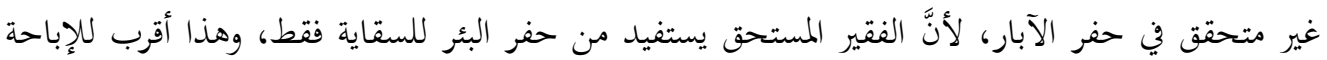
منه إلى التمليك.

7- فيما يتعلق بحكم ضمان حافر البئر في الفقه الإسلامي بند أنَّ الفقهاء متفقون على عدم

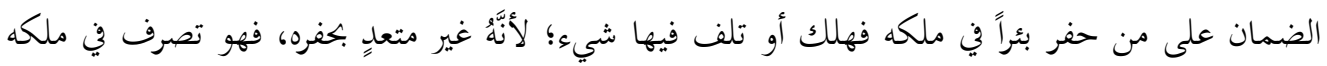

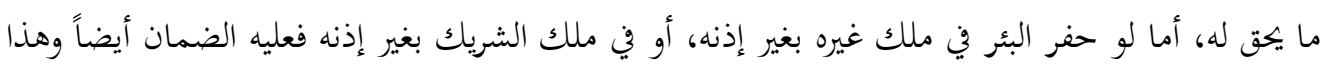

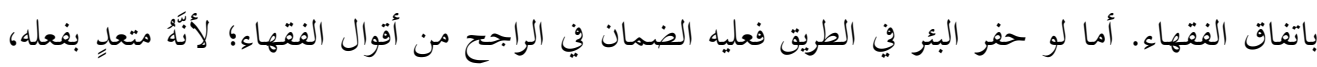
والمعتدي يضمن. 8- وضع وحلَّد المشرِّع الوضعي أحكاماً وشروطاً وضوابطَ وتعليمات لحفر الآبار بدقة، واشترط

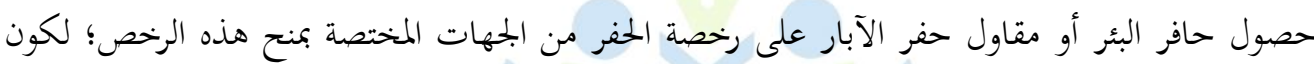

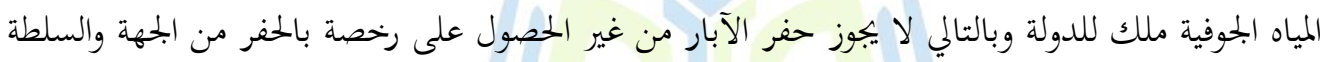

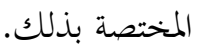

9- الالتزام بأحكام حفر الآبار وشروطه وتعليماته يعدُّ واجباً شرعياً وقانونياً ينبغي لكل من يقدم

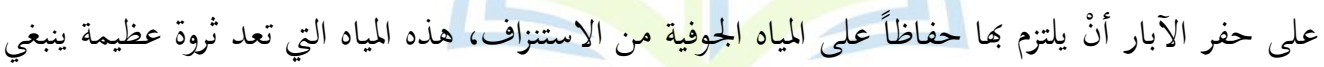
أن نحافظ عليها ولاسيّما في الوقت الحاضر إذ يواجه العالم اليوم أزمة شحة المياه وقلتها، وحفاظاً على مياه

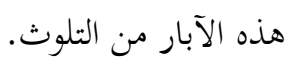

10- فيما يتعلق بحكم ضمان حافر في القانون الوضعي بند أنَّ القانون المدني العراقي رقم 40 بن 4010

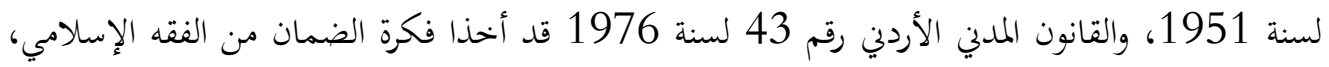

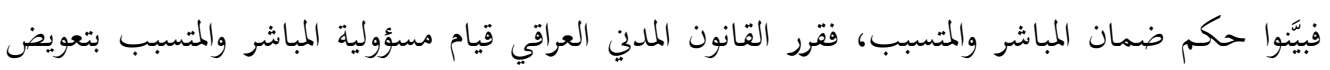

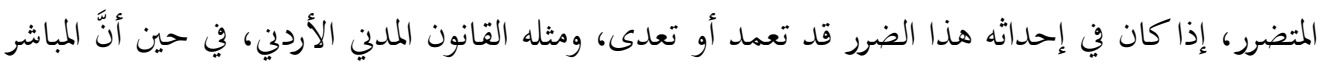

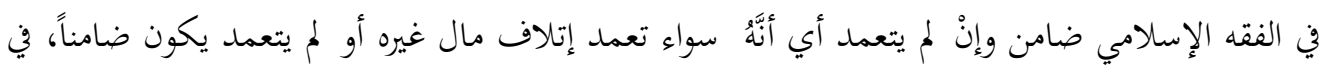

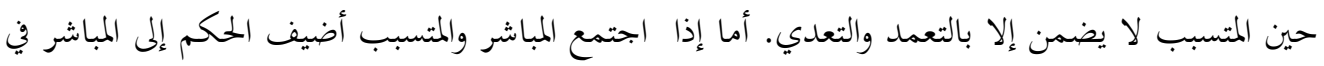


الفقه الإسلامي، أما في القانون المدني العراقي والذي حوَّر هذه القواعد الفقهية فاشترط التعمد أو التعدي

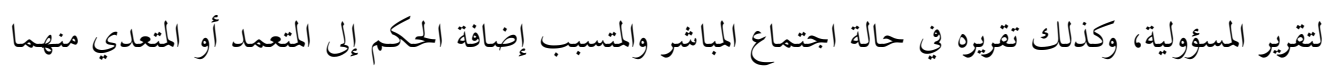

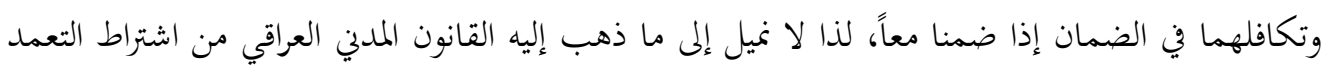

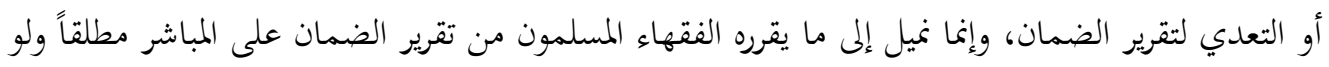

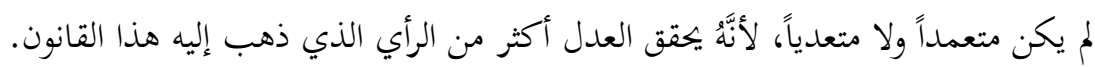

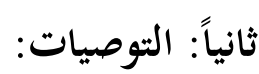

1- ضرورة حصول حافر البئر أو مقاول الحفر على رخصة الحفر من الجهات والسلطات المختصة

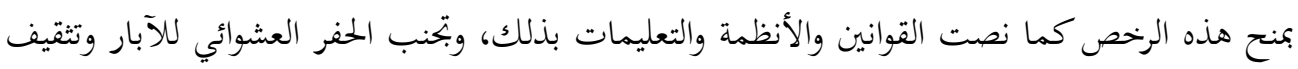

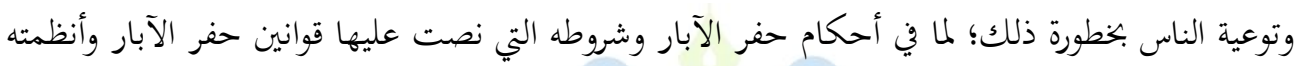

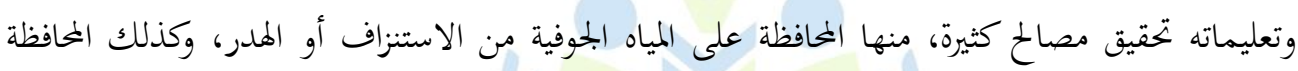

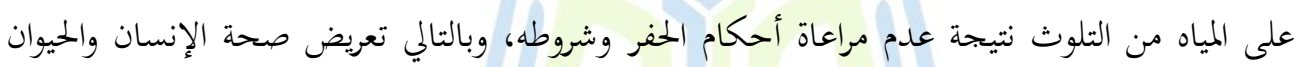

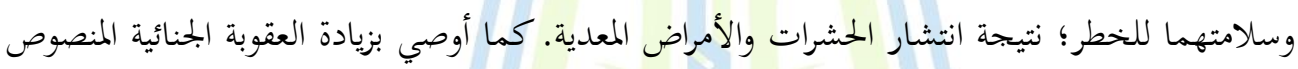

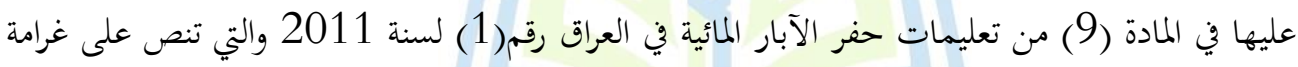

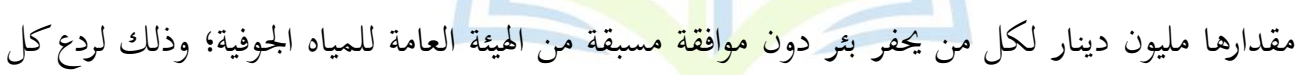

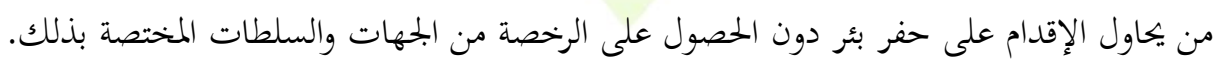

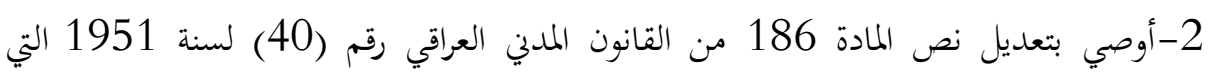

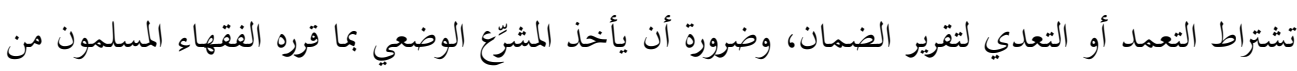

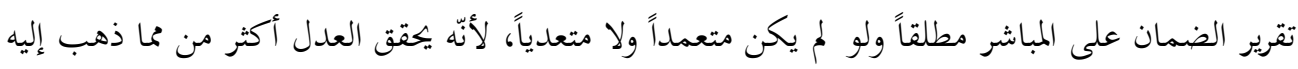

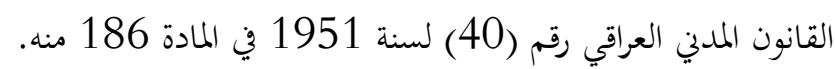
3- ضرورة التوسع في البحوث والدراسات الشرعية والقانونية، وعقد المؤتمرات والندوات المختلفة لماته

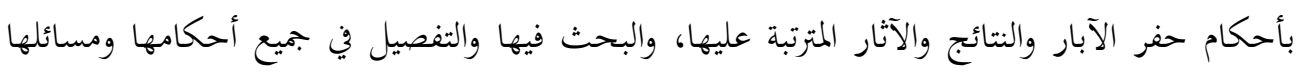
الشرعية والقانونية. 
ختاماً إنَّ ما أوردناه هو اجتهادات شخصية تقبل الخطأ والصواب، فالكمال لله وحده، والبشر محكوم عليه بالنقص والقصور عن إدراك كل الأمور.

\section{ثبت المصادر

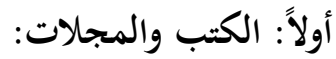

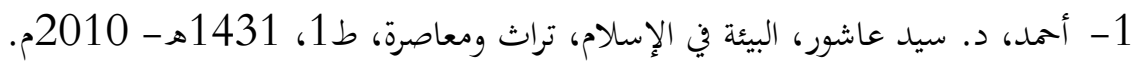

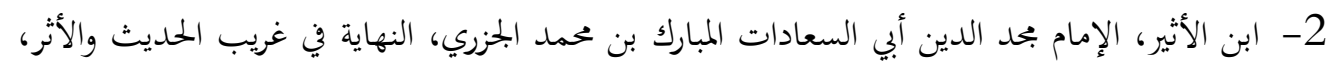

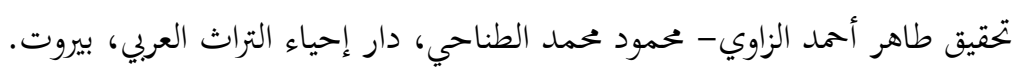

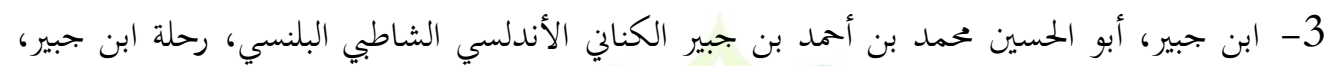

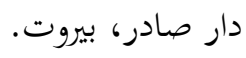

4- ابن حجر العسقلاني، أحمد بن علي، فتح الباري شرح صحيح البخاري، تقديم وتحقيق وتعليق

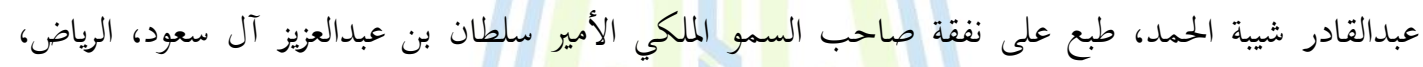

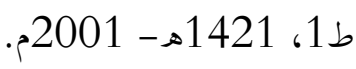
5- ابن خلكان، أبو العباس شمس الدين أحمد بن محمد بن أبي بكر، وفيات الأعيان وأنباء ابناء الزمان، حقَّقه الدكتور إحسان عباس، دار صادر، بيروت.

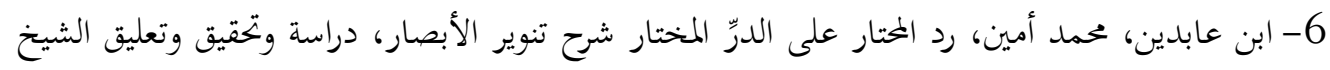

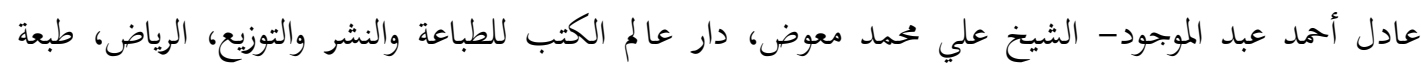
خاصة 1423هـ - 2003م، طُبعت هذه الطبعة بموافقة خاصة من دار الكتب العلمية، بيروت.

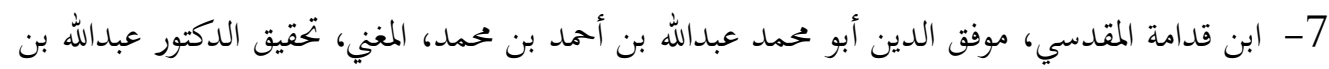

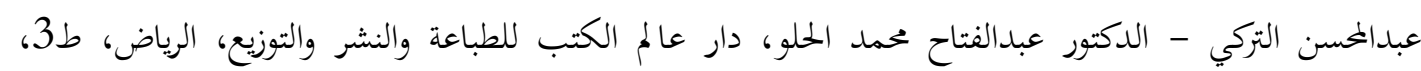

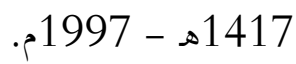


8- ابن منظور، العلاًّة أبو الفضل جمال الدين عمد بن مكرم ، لسان العرب، دار صادر، بيروت، ط5،

9- ابن نيم، العلامة الشيخ زين الدين بن إبراهيم بن محمد، الأشباه والنظائر على مذهب أبي حنيفة

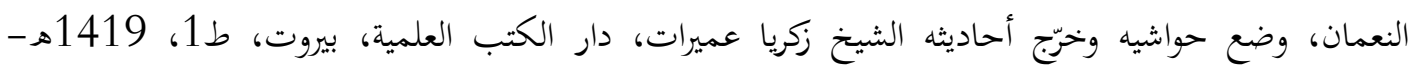

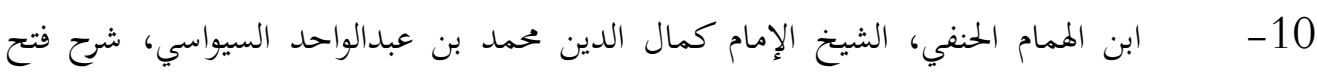

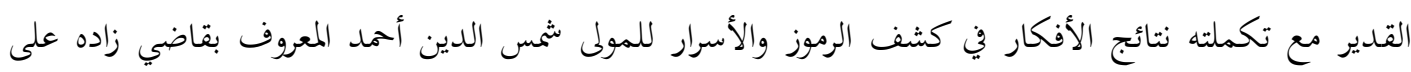

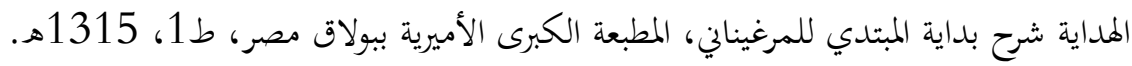

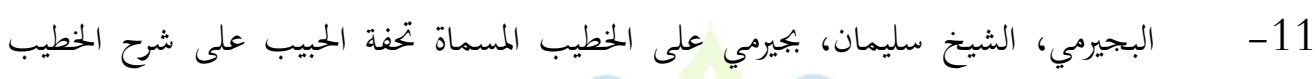

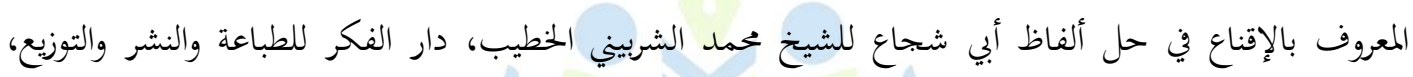

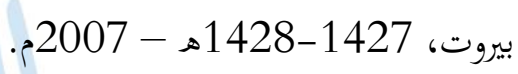

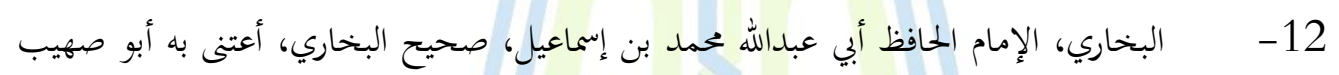

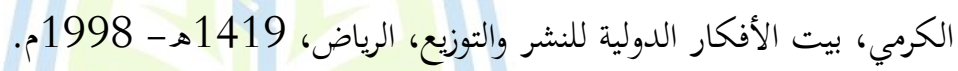

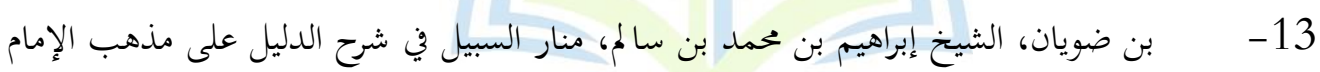

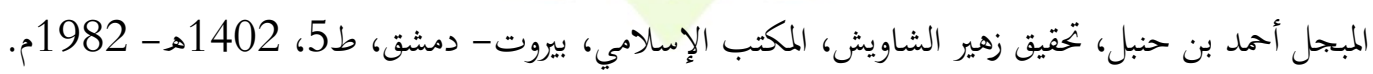

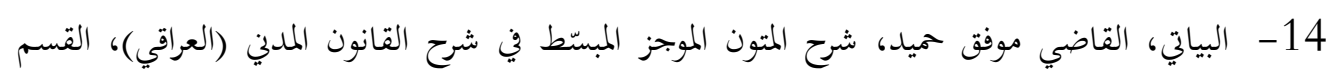

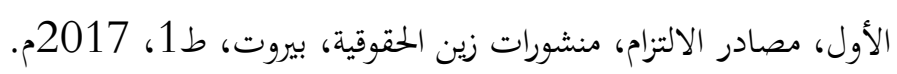

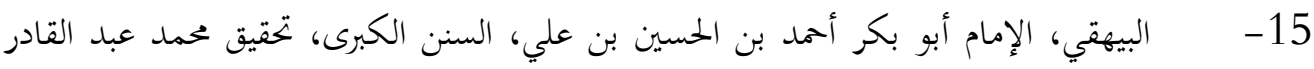

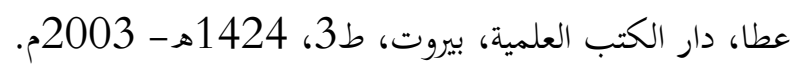

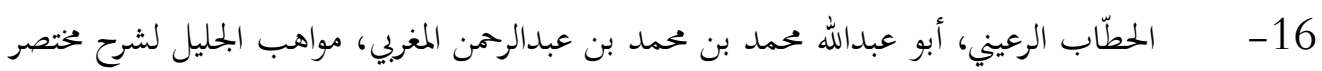

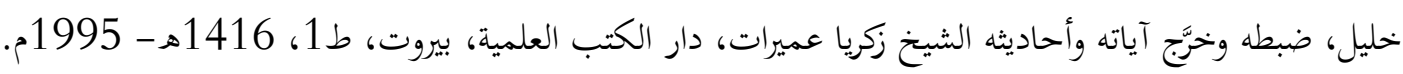


17- الحكيم، د. عبد البحيد، الموجز في شرح القانون المدني، ج1 مصادر الالتزام، ط4، المكتبة

القانونية، بغداد، 1974.

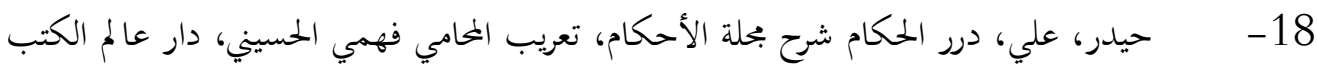

للطباعة والنشر والتوزيع، الرياض، طبعت هذه الطبعة بموافقة خاصة من دار الجيل، بيروت، طبعة خاصة -

19- الخطيب الشربيني، شمس الدين محمد بن الخطيب، مغني المختاج إلى معرفة معاني ألفاظ المنهاج،

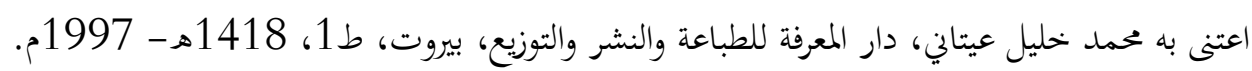

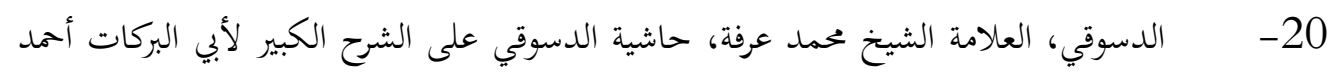

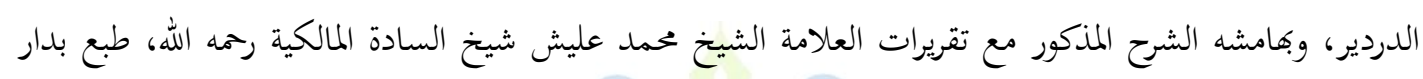
احياء الكتب العربية عيسى البابي الحلبي وشركاه.

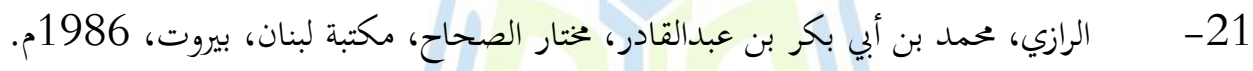

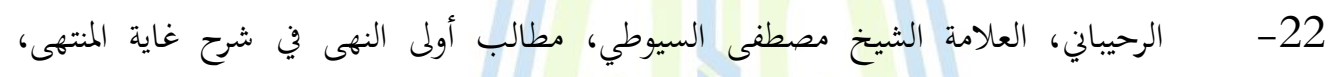

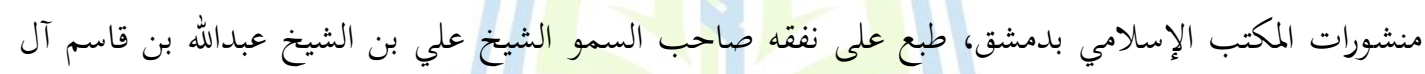
ثناني. 23- - الزحيلي، وهبة، التفسير المنير في العقيدة والشريعة والمنهج، دار الفكر، دمشق،1006، 1430هـ - 2009م.

24- الز الزحيلي، أ. د. وهبة، نظرية الضمان أو أحكام المسؤولية المدنية والجنائية في الفقه الإسلامي

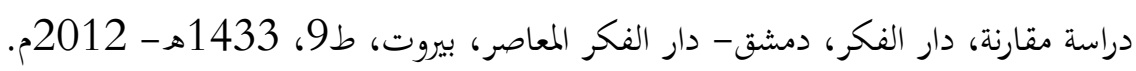

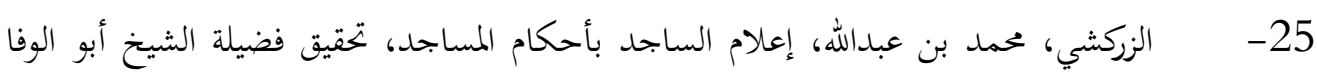

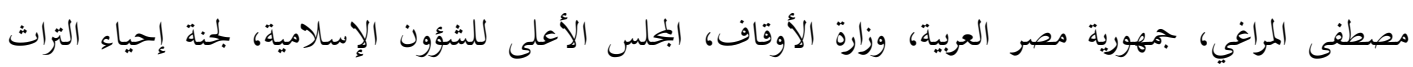

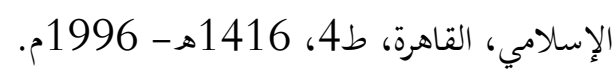


26- زكريا الأنصاري، زين الدين أبو يجيى زكريا بن محمد، أسنى المطالب شرح روض الطالب، دون دار نشر وطبعة وسنة

27- زيدان، د. عبدالكريم، المفصل في أحكام المرأة والبيت المسلم في الشريعة الإسلامية، مؤسسة

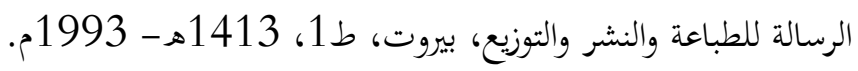

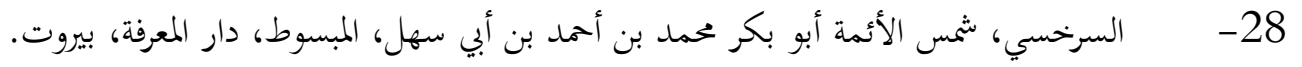

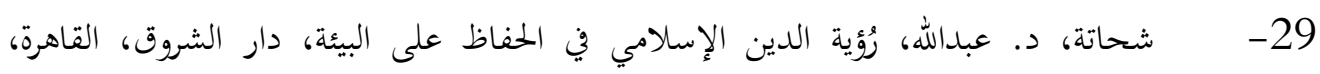

30- - العلامة العارف بالله الشرواني، الشيخ عبدالحميد - - والإمام الحقق والعلامة المدقق العبادي، الشيخ أحمد بن قاسم، حواشي تحفة المحتاج بشرح المنهاج، المكتبة التجارية الكبرى بمصر .

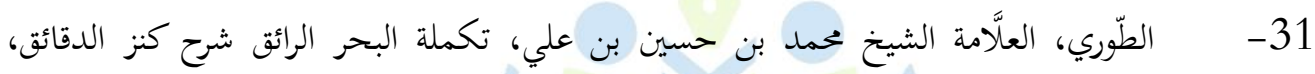

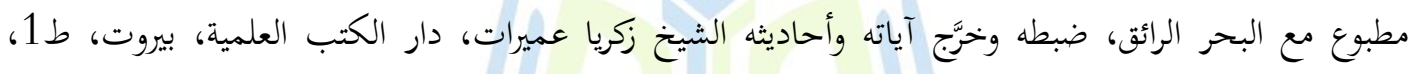

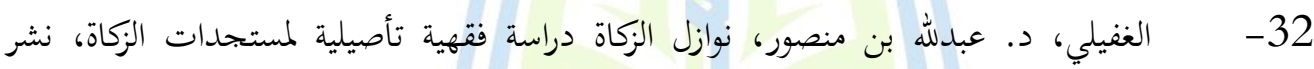

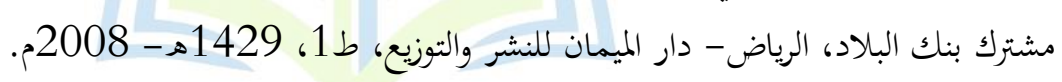

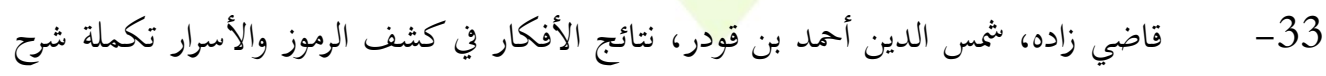

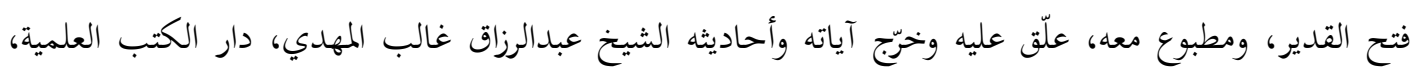

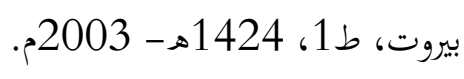
34- القرطبي، أبو عبدالله محمد بن أحمد بن أبي بكر، الجامع لأحكام القرآن، تحقيق الدكتور عبدالله

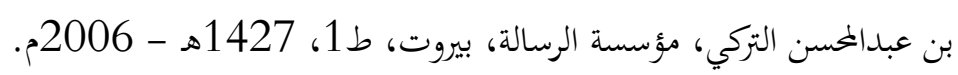

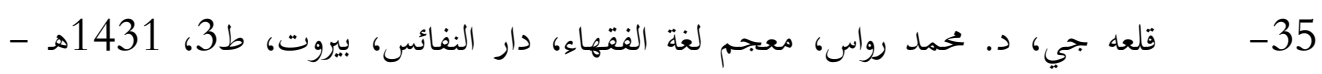


36- الكاساني، الإمام علاء الدين أبي بكر بن مسعود، بدائع الصنائع في ترتيب الشرائع، تحقيق

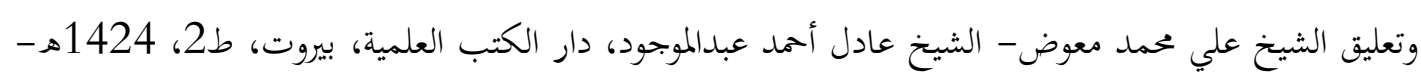
2003

37- كحالة، عمر رضا،اعلام النساء في عالمي العرب والإسلام، مؤسسة الرسالة للطباعة والنشر والتوزيع، بيروت.

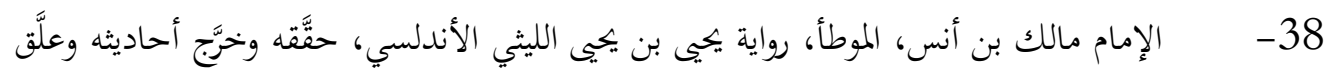

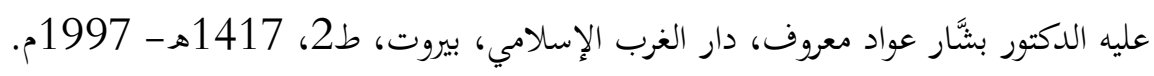

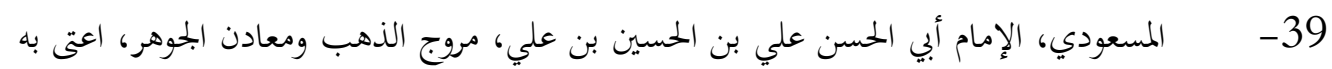

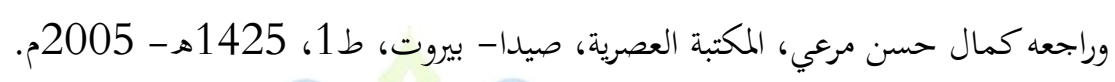

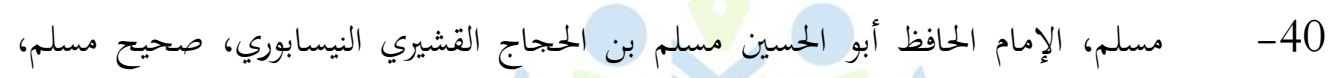

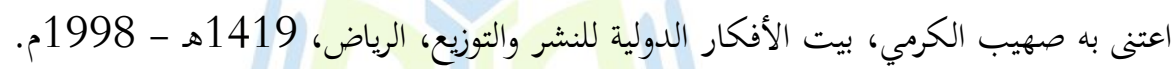

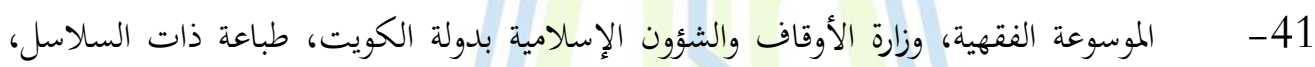
الكويت، ط2، 1408هـ- 1988م.

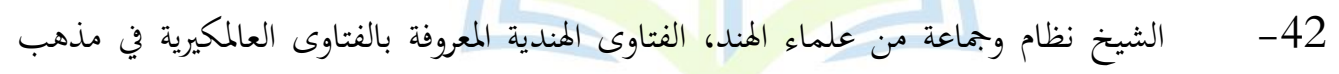

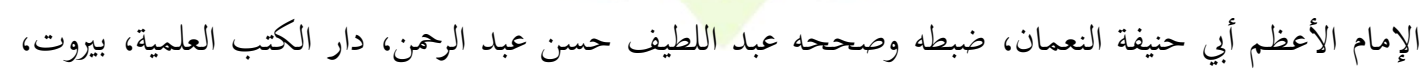

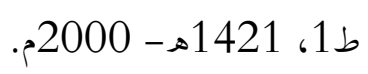

43- النووي، محيي الدين يميى بن شرف، صحيح مسلم بشرح النووي، المطبعة المصرية بالأزهر،

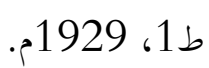

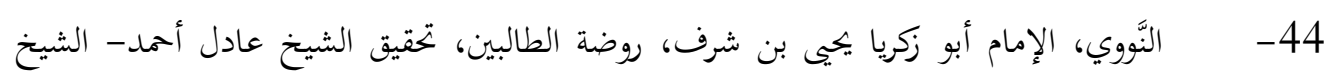

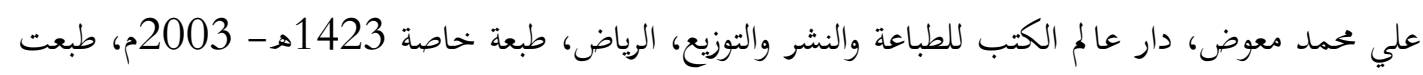

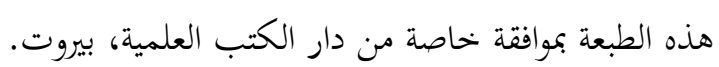
الوقائع العراقية الجريدة الرمية لمجمورية العراق. $-45$ 
46- الونشريسي، أبو العباس أحمد بن يهيى، المعيار المعرب والجامع المغرب عن فتاوى أهل إفريقية

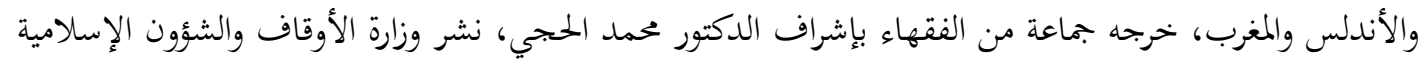

$$
\begin{aligned}
& \text { للملكة المغربية، 1401هـ - 1981م. والاندلم } \\
& \text { ثانياً: القوانين والأنظمة والتعليمات: }
\end{aligned}
$$

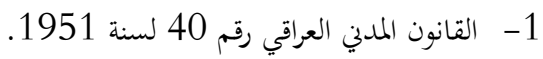

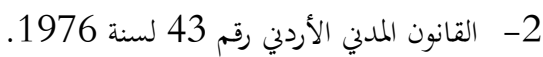

$$
\begin{aligned}
& \text { 3- قانون رقم } 1 \text { لسنة } 1988 \text { بتنظيم حفر آبار المياه الجوفي المعدل في دولة قطر. } \\
& \text { 4- - نظام مراقبة المياه الجوفية لسنة } 2002 \text { المعدل في الأردن. } \\
& \text { 5- قانون رقم 6لسنة } 2006 \text { بشأن تنظيم حفر آبار المياه الجوفية في إمارة أبو ظبي في الإمارات العربية المتحدة. } \\
& \text { 6- تعليمات حفر الآبار المائية رقم } 1 \text { لسنة } 2011 \text { في العراق. }
\end{aligned}
$$

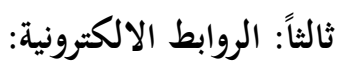

1- https://www.islamweb.net/ar/fatwa/357022

2- https://2u.pw/wwKd1 